\title{
Biomarkers of chronic non-specific airway diseases : an application of molecular epidemiology in occupational settings
}

Citation for published version (APA):

Keman, S. (1997). Biomarkers of chronic non-specific airway diseases : an application of molecular epidemiology in occupational settings. [Doctoral Thesis, Maastricht University]. Maastricht University. https://doi.org/10.26481/dis.19971120sk

Document status and date:

Published: 01/01/1997

DOI:

10.26481/dis.19971120sk

Document Version:

Publisher's PDF, also known as Version of record

Please check the document version of this publication:

- A submitted manuscript is the version of the article upon submission and before peer-review. There can be important differences between the submitted version and the official published version of record.

People interested in the research are advised to contact the author for the final version of the publication, or visit the DOI to the publisher's website.

- The final author version and the galley proof are versions of the publication after peer review.

- The final published version features the final layout of the paper including the volume, issue and page numbers.

Link to publication

\footnotetext{
General rights rights.

- You may freely distribute the URL identifying the publication in the public portal. please follow below link for the End User Agreement:

www.umlib.nl/taverne-license

Take down policy

If you believe that this document breaches copyright please contact us at:

repository@maastrichtuniversity.nl

providing details and we will investigate your claim.
}

Copyright and moral rights for the publications made accessible in the public portal are retained by the authors and/or other copyright owners and it is a condition of accessing publications that users recognise and abide by the legal requirements associated with these

- Users may download and print one copy of any publication from the public portal for the purpose of private study or research.

- You may not further distribute the material or use it for any profit-making activity or commercial gain

If the publication is distributed under the terms of Article $25 \mathrm{fa}$ of the Dutch Copyright Act, indicated by the "Taverne" license above, 


\section{Biomarkers of \\ Chronic Non-specific Airway Diseases}

An application of molecular epidemiology in occupational settings 


\section{Biomarkers of Chronic Non-specific Airway Diseases}

An application of molecular epidemiology in occupational settings

\section{Proefschrift}

ter verkrijging van de graad van doctor aan de Universiteit Maastricht, op gezag van de Rector Magnificus, Prof. Mr. M.J. Cohen, volgens het besluit van het College van Dekanen, in het openbaar te verdedigen op Donderdag, 20 November 1997, om 14.00

door

Soedjajadi Keman

geboren te Surabaya, Indonesië, op 15 Maart 1952 
Promotor:

Prof. Dr. J.C.S. Kleinjans

Co-promotor :

Dr. P.J.A. Borm

Beoordelingscommissie :

Prof. Dr. E.F.M. Wouters (voorzitter)

Dr. G. Doekes (Landbouwuniversiteit Wageningen)

Prof. Dr. H.F.P. Hillen

Prof. Dr. J.J. Manni

Dr. G.M.H. Swaen

CIP-DATA KONINKLIJKE BIBLIOTHEEK, DEN HAAG

Keman, Soedjajadi

Biomarkers of chronic non-specific airway disease: an application of molecular epidemiology in occupational settings / Soedjajadi Keman - Maastricht

Unigraphic, Maastricht University

Thesis - Maastricht University

ISBN 90-5681-022-7

Subject headings : Biomarkers / Occupational respiratory disease

Printed by : Unigraphic, Maastricht University, Maastricht, The Netherlands

The studies presented in this thesis were financially supported by Indonesian Six Universities Development and Rehabilitation (SUDR) project. European Committee for Steel and Coal (ECSC) grant 7263/03/92, and project 229.764 of Nutrition Toxicology and Environment Research Institute Maastricht (NUTRIM) / Toxicology Division. 
Dedicated to:

My mother, my wife, and my sons. 


\section{CONTENTS}

Chapter 1. General Introduction $\quad$...............................................

1.1. Exposure-Effect Relationships $\quad$............................ 13

1.2. Chronic Non-specific Airway Diseases $\quad$............... $\quad 16$

1.2.1. Occupational Asthma $\quad$...................................... 16

1.2.2. Chronic Obstructive Pulmonary Diseases ........... $\quad 20$

1.2.2.1. Chronic Bronchitis $\quad$.......................... 21

1.2.2.2. Emphysema $\quad$........................................ 23

1.3. Assessment of Chronic Non-specific Airway Diseases .... 24

1.3.1. Questionnaire …........................................... 24

1.3.2. Lung Function Measurement ……................... 25

1.3.3. Radiographic Techniques $\quad$................................... 26

1.3.4. Bronchoalveolar Lavage $\quad$.................................... $\quad 27$

1.3.5. Nasal Lavage $\quad$.................................................. 28

1.3.6. Whole Blood and Serum Cytokine Assays ........... $\quad 30$

1.4. Aims and outline of the dissertation …......................... 32

References

Chapter 2. A five year follow-up of lung function among chemical workers using flow volume and impedance measurements

Chapter 3. Blood interleukin-8 production is increased in chemical workers with bronchitic symptoms

Chapter 4. Blood cytokines in coal dust induced respiratory disorders

Chapter 5. Longitudinal changes in inflammatory markers in nasal lavage of cotton workers: relation to endotoxin exposure and lung function changes

Chapter 6. Relations between inflammatory markers in serum and nasal lavage

Chapter 7. General discussion

References

Chapter 8. Summary 
Chapter 1.

\section{GENERAL INTRODUCTION}

Chronic non-specific airway diseases in particular associated with occupational exposure, constitute a growing health problem and have been the focus of international concern (Oxman, 1993; Becklake, 1995). The growth of research in epidemiology of occupationall respiratory diseases over the last 30 years has increased the knowledge about occupational lung diseases and led to refinements in and standardization of study design and methods of analysis. An understanding of occupational epidemiology depends on knowing about the relationship between an occupational exposure and disease. Chronic non-specific airway diseases are common conditions with several causes, some of them encountered at workplace. Occupational exposures are important 'natural experiments" in disease induction. The timing, intensity and duration of exposure are often known more accurately for occupational than for nonoccupational causal agents. Workers can be exposed to many potential workplace hazards (such as chemical and biological agents) which can lead to chronic airway diseases. Individual genetic susceptibility and cigarette smoking have been identified as important risk factors (Cullinan, 1991; Woolcock, 1992; Becklake, 1994; Postma et al., 1995).

Already in 1961 the Dutch hypothesis was put forward that asthma, chronic bronchitis, and emphysema should be considered as separate diseases of one disease-entity called 'chronic non-specific airway disease' (Sluiter et al., 1991). Because of the two terms, chronic bronchitis and emphysema, have been used in the literature without sufficient information provided to group subjects and often impossible to discriminate into diagnostic classifications, it may be necessary to refer to information collected under a board designation such as chronic obstructive airway or pulmonary disease (COPD) (Sluiter et al., 1991; Christiani, 1994). Both internal (host) and external (environmental or occupational) factors are thought to play a role in the pathogenesis. Predisposition to develop allergy and bronchial hyperreactivity is considered as an important internal factor of disease susceptibility. Diffuse airway obstruction is considered as the common pathophysiological characteristic. Recently, molecular epidemiology has been developed to illuminate disease mechanisms. Detection of immunological and pathophysiological changes offers an alternative opportunity to prevent adverse airway effects from occupational exposures. Nowadays we know that immunological and (chronic) inflammatory response play a pivotal role in the pathogenesis of airway disease. In the near future there will be a need for surveillance and screening programs carefully monitoring early adverse health effects. It is the relative inability to detect early signs of environmentally related adverse health effects that has prompted much interest in using biochemical and pathological changes in cells and tissues as biological indicators (biomarkers) for chronic respiratory diseases in general (Borm, 1994). Biomarkers may represent signals in a continuum of events between causal exposure and resultant disease (Schulte, 1989). The continuum between exposure and disease has been characterized by several others (National 
Research Council, 1987; Perera, 1987) and contains at least 7 generic components, as shown in Figure 1.1. The continuum is a temporal sequence, where the higher one precedes a lower one. Events in the upper three blocks can be considered as markers of exposure and events in the lower three to four blocks as markers of effects. Any early biological event derived from biochemical, molecular, genetic, immunologic, or physiological signals is ambiguous prior to study and may turn out to be neither at the end. Markers of susceptibility, as indicated in the flow diagram are indicators of increased (or decreased) risk at any stage in this framework.

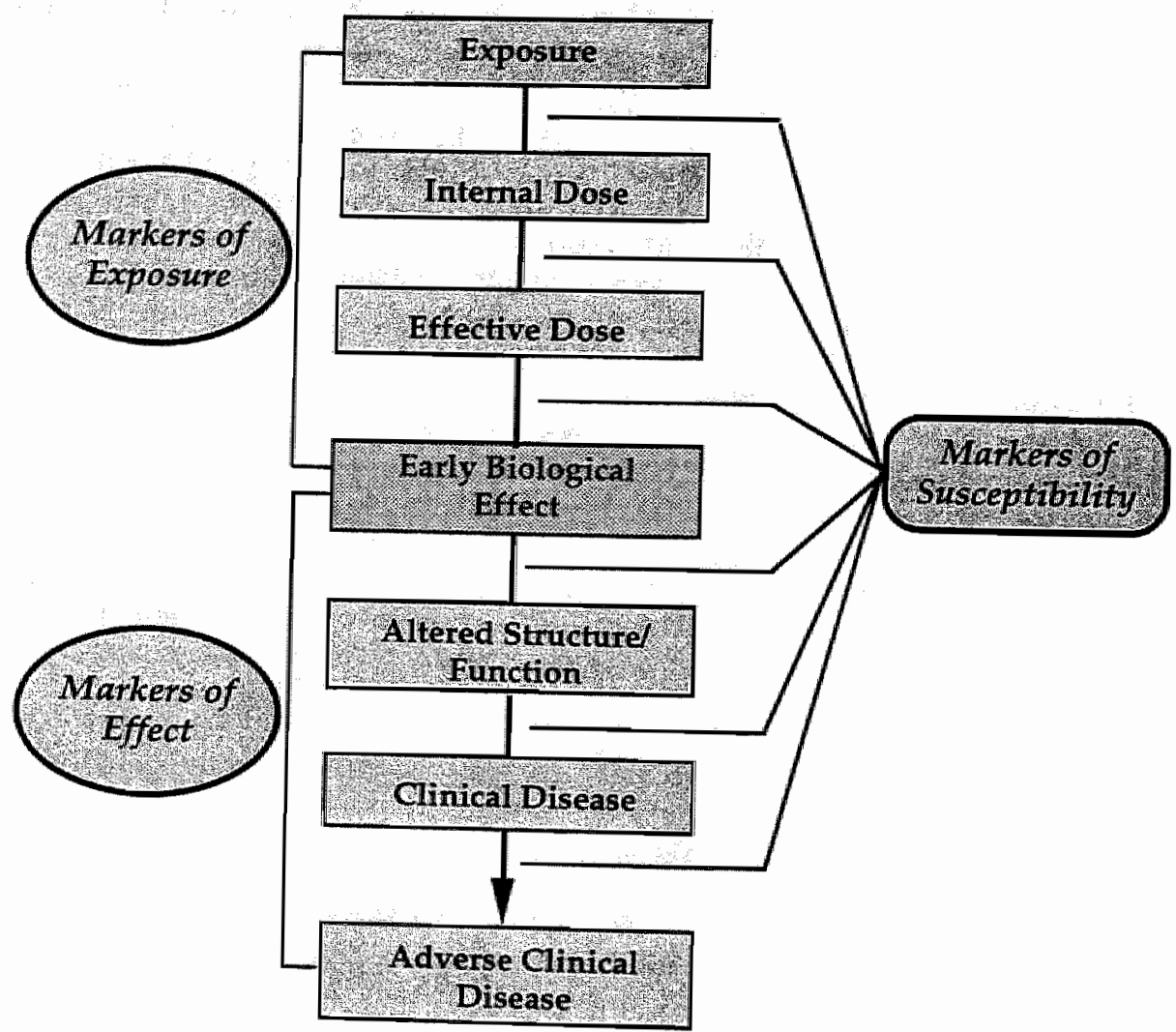

Figure 1.1. Biological warkers components in a sequence between exposure and disease Behween enoironmental exposure and possible development of adverse clinical disease, four sequential events relating to conform classes of biological markers have been identified: internal dose, the anount of xenobiatic substance found in a biological medium; biologically effective dose, the amount interacting with the critical subcellular, cellular, and tissue targets; early biological effect, an event correlated with, and possibly predictive of health impaiment; and altered structural furction, an aprodromal biological change more closely related to the development of disease. Markers of disease and adverse health effects reflect the presence and future of developed disease (Adapted from Committee on Biological Markers, National Research council, 1978; and modified by Borm, 1994). 
During the past decade, cytokines have come to the fore as important multifunctional mediators of cell behavior and cell to cell communication. Alteration in cytokine production, secretion, and action are driving forces in chronic non-specific lung disease, but there is no one-to-one relation between specific diseases and individual cytokines (Kelley, 1990). In chronic non-specific airway diseases, interleukin-8 (IL-8) and tumor necrosis factor- $\alpha$ (TNF- $\alpha$ ) have been shown to be increased in sputum (Richman-Eisenstat et al., 1993; Keating et al., 1996) and bronchial lavage fluid (Riise et al., 1995) of patients with chronic bronchitis, and plays an important role in the development of clinical respiratory disease (Donnelly et al., 1993; Broaddus et al., 1992; Lynch et al., 1992). In hyperresponsiveness, interleukin-4 (IL-4), interleukin-5 (IL-5) are increased and interferon- $\gamma$ (IFN- $\gamma$ ) is decreased, which is known as the ' $\mathrm{Th}_{2}$ hypothesis' (Holtzman et al., 1996). An essential requirement for a successful biomarker of effect or susceptibility is that it should identify from among all exposed individuals those most likely to become diseased. Although this may seem simple, a lot of effort has to be invested before the validity of a biomarker is known.

Prevention of adverse airway effects from occupational exposures can be done through occupational risk analysis and preventing the worker from workplace exposure. It may be very challenging but is often very difficult, because many agents appear in a diverse range of materials and processes, and often unlabelled minor constituents or concomittants makes it hard to recognize the presence of these minor materials (Cullen, 1990-a;-b). Occupational epidemiology both tests and generates hypotheses about the cause of occupational disease. A hypothesis to test may come from a clinical observation of a cluster of cases of disease within a factory. This chapter reviews the role of occupational exposure in the nature of chronic non-specific airway diseases, possible immunopathologic mechanisms involved, currently applied methods, and the possibility of biomarkers as an alternative for the detection of those diseases.

\subsection{Exposure-Effect Relationships}

Evidence of an association between workplace exposure and chronic nonspecific airway diseases have been greatly strengthened over the last decade, both from work forced based studied (in which the confounding effects of smoking have been taken into account) and from community based studies (which avoid selection bias both into and out of a workplace i.e. 'healthy' worker effect), to the point where there is now general acceptance that workplace exposures are a cause of chronic airway disease (Becklake, 1989-a). Ideally, exposure recieved should be measured at the target tissue but in most conditions the dose is not measureable in practice. There are several approaches to measure exposure in occupational epidemiology which depend on the type of data available such as body burden, airborne concentration, exposure intensity, cumulative exposure, duration, and exposed/unexposed groups. For many agents causing chronic non-specific airway diseases, it is not known whether dose, mean exposure or (intermittent) peaks are important. However, it has been reported (Brooks and Kalica, 1987) that 
intermittent peak exposures to airway irritants can cause airway hyperresponsiveness ( $\mathrm{AHR}$ ) and that the number of peak exposures can be a. better descriptor of lung function (Tornling et al., 1990) than the average exposure.

Occupational exposures to organic dust have been known to give rise to asthma (Bernstein et al., 1993). Examples of such exposures include cotton dust, grain dust, swine dust, and wood dust. Exposure to cotton dust is associated with acute work-related symptoms of byssinosis, as well as chronic airway obstruction and chronic bronchitis. Although the acute syndrome of byssinosis appears to be related to biologically active components in the bract (gram negative bacterial endotoxin alone or in combination with bract material), the chronic airway obstruction may be related to other dust chracteristics or to non-specific inflammatory responses to inhalable dust (Christiani, 1994). Chronic exposure to grain dust also has been associated with chronic bronchitis, chronic wheezing, and an accelerated loss of lung function (Enarson et al., 1985). The clinical conditions generally encompassed by the term COPD are clearly multifactorial in origin. However, tobacco smoking and $\alpha 1$-antitrypsin deficiency were the only factors accepted as being causally related to COPD (Cullian, 1991; Becklake, 1994). Host susceptibility factors such as atopic status, airway hyperresponsiveness, prior respiratory health, as well as environmental and occupational exposures were listed as putative causes (Christiani, 1994). Although more research is needed to quantify exposure-effect relationships and to assess mixed exposures, there is a preponderance of scientific data supporting the hypothesis that mineral dust exposure causes chronic airway disease in human. Hence, there is growing evidence that long-term occupational exposure places workers at increased risk of developing chronic non-specific airway diseases.

Populations with contrasting exposures are needed for assessing whether an exposure causes a disease or for quantifying the relationship between exposure and disease. Occupational groups with an unusually heavy exposure are very waluable. Often, the past exposure provides a valuable information and that is why epidemiological studies use historical data, especially in diseases with a long latency interval such as chronic bronchitis and occupational asthma (Venables et al., 1984). A recent study on AHR in 688 male workers exposed to low level's irritants (Kremer et al, 1995) showed a lower prevalence of AHR in subjects with less than 5 years exposure to $\mathrm{SO}_{2}$ and oil mist probably due to preemployment screening. No association between $\mathrm{AHR}$ and low grade exposure to irritants, however, could be established. Brochard et al (1987) observed normal flow volume curves but altered impedance values in a group of 36 workers exposed to respiratory irritants ( $>6$ years) in gas manufacturing plant compared to the outcome of 46 non-exposed references ( $<6$ years' employment) from the same plant.

The contribution of accupational exposures to the pathogenesis of respiratory diseases is still underestimated (Becklake, 1989-a,-b), but certainly underrecognized in the practice of clinical and occupational medicine (Morgan, 1986). Studies of the respiratory effects of occupational exposures have usually been workforce-based. These kind of studies have the advantage of better characterization of the environment. Disadvantages include limited population 
size, limiting power, and healthy-worker effect bias. On the contrary, in community-based studies, sample size is large, but usually depend on self-reports of occupational exposures. However, such studies have been very informative in identifying causal relationships between occupational exposure and respiratory disease. Most published studies of occupational respiratory disease have been cross-sectional studies. These studies have been very useful for determining the prevalence of pneumoconiosis, but are less useful for studying a hypothesized association between occupational exposure and chronic airway obstruction. This is because the confounding effects of cigarette smoking and age contribute less to the noise in measurement in studies in which outcome measurement is radiographic opacities of pneumoconiosis in comparison to studies in which the outcome measurement is lung function (occupational asthma, chronic bronchitis or emphysema). Whereas longitudinal studies have the advantage of decreasing inter-individual variation (noise) in lung function, therefore enhancing the signal of interest, namely effects of the occupational exposure.

In contrast to the community-based studies, most workforce-based studies are supported by quantitative exposure measurements. However, valiant the attempts at detailed direct measurements, measurement error and misclassification are inevitable, and this will weaken exposure-response relationships. Such error and misclassifications are confounded by the healthy worker effect'; selection bias due to those in better health being self-selected or selected by medical examination into a workforce and remaining in it, while the opposite occurs for those who become ill (Becklake, 1989-a; Higgins, 1989). It is noteworthy, both these potential sources of bias tend to result in underestimation, not overestimation of the effects of occupational exposure.

Since January 1989, specialists in occupational and thoracic medicine throughout the United Kingdom have reported newly diagnosed cases to a scheme for the Surveillance of Work Related and Occupational Respiratory Disease (SWORD) (Meredith and McDonald, 1994). By the end of February 1995, SWORD had received details of 1452 cases of occupational respiratory disease first identified in 1994, giving an estimated total of 3267 cases based on the sampling method. Diseases of long latency accounted for $45 \%$ of all reports, followed by asthma $(31 \%)$ and inhalation accidents (14\%). Asbestos was the attributed cause in $92 \%$ of reports of long-latency disease ( 1529 cases), but, of these, it accounted for lower proportion of 132 cases of pneumoconiosis (74\%) and 26 cases of lung cancer $(65 \%)$. Apart from asbestos, pneumoconiosis cases were also ascribed to sillica $(11 \%)$ and coal $(11 \%)$, and the remainder were ascribed to welding fumes, talc, stone and other dusts $(4 \%)$. Lung cancer was also attributed to radon, cadmium, chromium and aluminium; it is probably the most under-reported category of diseases of long latency (Ross et al., 1995). There is also likely a biological interaction between cigarette smoking and occupational exposure in the development of respiratory disease. As smoking impairs long-term dust clearance from the lung, the effect of other inhaled agents could be enhanced (Becklake, 1989a).

In a generic genotype-environment interaction model, we can consider that there is a susceptibility genotype to an environmental exposure. Among unexposed individuals without the susceptible genotype there exist a certain 
background risk of disease, reflecting etiologic heterogenecity. Relative risk or odds ratios of disease corresponding to the different combinations of genotype and exposure can be calculated from cohort and case-control studies respectively (Khoury et al., 1988). In addressing the issue of chronic non-specific airway diseases, this part consider a broader spectrum of recent trends in epidemiology and pathogenesis of these diseases in occupational settings, including asthma and COPD.

\subsection{Chronic Non-specific Airway Diseases}

Most agents associated with chronic non-specific airway diseases gain access via the inhalation route. The maintenance of health depends on the ability of the host to achieve rapid elimination of the offending agent, and the first line, non-specific immune defence barriers of the respiratory tract clear most inhaled agent before they ever reach the sub-epithelial tissues or other internal regions. The barriers include nasal hairs, the nasal and respiratory secretions or saliva, cilliated epithelial cells, and aided by mechanical propulsion mechanisms such as coughing, sneezing, and swallowing. These defences operate without any requirement for prior contact with, or specific sensitization to, the foreign invader. When the non-specific defence barriers are unable to eliminate the offending agent, the second line specific immune defence mechanisms that guards the tissues and other internal organs will be activated. These defences are mediated by specialized antigen-presenting cells and lymphocytes, and can induce chronic inflammation thereby contributing the pathogenesis of chronic non-specific airway diseases. There are various factors such as properties of the agent, host factors, secondary factors that can influence host immune response, atopic status and genetic susceptibility that need to be taken into account to understand why certain dust can escape the normal immune defences and stimulate immune hypersensitivity reactions in the lung or airways (Parkes, 1994).

\subsubsection{Occupational Asthma}

The term 'asthma' does not describe a single disease but a syndrome with similar symptoms but different etiology. The differences between the several manifestations of asthma have diagnostic, therapeutic, prognostic and preventive umplications (Ross et al., 1995). According to clinical criteria atopicallergic, intrinsic, occupational and mixed-type asthma can be differentiated. Occupational asthma is the most frequently diagnosed occupational lung disease reported to the SWORD scheme (Ross et al., 1995). Occupational asthma is characterized by variable airflow limitation and/or airway hyperresponsiveness due to causes and conditions attributable to a particular occupational environment and not to stimuli encountered outside the workplace (Bernstein et al., 1993). Typical for asthma, airflow limitation is reversible over short periods of time, either spontaneously or as a result of treatment (Newman Taylor, 1994). Two types of occupational asthma are distinguishable by whether or not they 
appear after a latency period. The first type is occupational asthma with a latency period - encompasses all instances of immunologic asthma for which an immunologic mechanism has been identified and includes both high and some low molecular weight agents. Another form of occupational asthma occurs without a latency period and follows exposure to high concentrations of an irritant product, best illustrated by irritant-induced asthma or the reactive airways dysfunction syndrome (RADS). It was originally defined as asthma occurring after a single exposure to high levels of an irritating vapor, fume, or smoke. Initial symptoms develop within minutes or hours after exposure. In the majority of cases there was continuation of obstructive symptoms and persistent airway hyperreactivity for more than one year (Malo et al., 1994). The pathogenesis of RADS is still speculative primarily because the clinical description of the syndrome thus far has been retrospective in nature (Brooks et al., 1985). Asthma is one of the commonest causes chronic ill-health in the UK, affecting approximately $5 \%$ of the adult population (Axon et al., 1995). Occupational asthma is also relatively common, being the most common occupational lung disease reported to SWORD. Although still the most commonly reported agents in occupational asthma, cases attributed to isocyanates have declined in number and as a proportion of cases. On the other hand, attribution to laboratory animals, acid anhydrates and proteolytic enzymes has increased (Ross et al., 1995).

It is important to prevent exposure and to remove sensitized workers from exposure to an occupational agent that may be cause of asthma, because occupational asthma can lead to permanent impairment (American Thoracic Society, 1993). Several retrospective studies have shown that the earlier the affected workers are removed from exposure to a causal agent present at workplace, the more likely they will recover (Chan-Yeung et al., 1982; Hudson et al., 1985).

Table 1.1. Characteristics of high and low molecular weight agents causing occupational asthma

\begin{tabular}{|l|c|c|}
\hline Parameter & High moleculat weight & Low molecular weight \\
\hline $\begin{array}{l}\text { Physical size } \\
\text { Inmunological mechanism }\end{array}$ & $\begin{array}{c}>5000 \text { daltons } \\
(\text { specific) lgE }\end{array}$ & $\begin{array}{c}<5000 \text { daltons } \\
\text { non IgE } \\
\text { cellullar involved }\end{array}$ \\
$\begin{array}{l}\text { Clinical } \\
\text { - predisposition } \\
\text {-interval between onset to symptoms } \\
\begin{array}{l}\text { Functional response after specific } \\
\text { inhalation challenges }\end{array}\end{array}$ & $\begin{array}{c}\text { atopy } \\
\text { long }\end{array}$ \\
$\begin{array}{l}\text { Prevalence } \\
\text { Examples of agent }\end{array}$ & $\begin{array}{c}\text { shorter } \\
\text { isolated immediate } \\
\text { dual } \\
<5 \%\end{array}$ & $\begin{array}{c}\text { late } \\
\text { atypical } \\
>5 \%\end{array}$ \\
isocyanates \\
\hline
\end{tabular}


The pathogenesis of asthma and, in particular, development of the chronic symptoms of bronchial inflammation and irritation requires the involvement of $\mathrm{T}$ lymphocytes and cellular immune processes (Corrigan and Kay, 1992). The prominent eosinophilic inflammation that characterizes asthma appears to be orchestrated by cytokines derived from type $2 \mathrm{~T}$-helper $\left(\mathrm{Th}_{2}\right)$-like lymphocytes, suggesting that immunosuppressants might be beneficial in the control of asthma. Indeed, one of the critical modes of action of glucocorticoids in controlling asthma may be the suppression of $\mathrm{Th}_{2}$-lymphocyte-derived cytokines, such as IL-5. A variety of chemicals (Table 1.1) has been implicated as causing occupational respiratory hypersensitivity, frequently, but not invariably, associated with the presence of specific immunoglobuline $\mathbb{E}$ (IgE) antibody (ChanYeung and Lam, 1986; Karol 1992). Unlike contact hypersensitivity, there are no widely accepted methods available for the prospective identification of chemical respiratory allergen. Progress towards the development of appropriate model systems has derived from animal studies, that showed that topical exposure of mice to known chemical respiratory allergens induced responses characteristic of the selective activation of $\mathrm{Th}_{2}$ cells (Kimber and Dearman, 1992), which produce $\mathrm{IL}-4$, a cytokine necessary for the synthesis of IgE antibody (Mosmann et al.1991). Conversely, contact allergen known or suspected not to cause respiratory hypersensitivity induce responses consistent with $T$ helper-1 $\left(\mathrm{Th}_{1}\right)$ cells (Kimber and Dearman, 1992). A product of $\mathrm{Th}_{1}$ cells, in IFN- $\gamma$ inhibits IgE antibody responses (Mosmann et al., 1991). Another key observation is that, presumably as a consequence of the preferential stimulation of $T_{2}$ cell-type responses and $\mathrm{L}-4$ production, topical exposure only to chemical respiratory allergens caused in mice an increase in the serum concentration of IgE. No such changes in IgE concentration were observed as a result of exposure to chemical allergens considered not to cause respiratory hypersensitivity (Dearman and Kimber, 1992). A distinguishing feature of the functional subpopulations of Th cells is that, following activation, they produce different spectra of cytokines (Figure 1.2).

It has been found recently that similar heterogenicity among human Th cells and cytokine production exists (Romagnani, 1995), although a clear division of CD4+ cells into $\mathrm{Th}_{1}$ and $\mathrm{Th}_{2}$ phenotypes is undoubtedly an oversimplification. Other Th populations have been described including $\mathrm{Th}_{0}$ cells, which produce cytokines of both $T h_{1}$ and $T h_{2}$ type (Mosmann et al., 1991). It is probable that $T h_{1}$ and $\mathrm{Th}_{2}$ cells represent in functional terms the most differentiated form of $\mathrm{CD} 4+$ $T$ lymphocytes and develop from common precursors (such as $T_{0}$ cells) during the evolution of an immune response (Kimber and Dearman, 1992). Also in main cytokines appear to play an important role in the development of Th populations. IL- 4 facilitates and may be essential for the generation of $\mathrm{Th}_{2}$ cells. In contrast, IFN- $\gamma$ favors the development of $\mathrm{Th}_{1}$ cells (Swain et al., 1991). The fact that cytokines produced by CD4+ cells have the ability to regulate reciprocally their own development and differentiation, suggests that any perturbation in the balance between $T h_{1-}$ and $T h_{2}$-type responses induced during immune activation will be sustained and amplified as the response progresses. The cellular source of the cytokines that initially provide the signals necessary for Th cells differentiation is of interest and it has been suggested recently that elements of the non-adaptive immune system are important in this respect. It is 


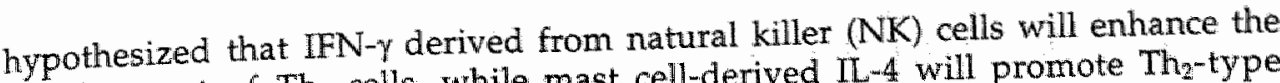
development of $\mathrm{Th}_{1}$ cells, while mast cell-derived $\mathrm{IL}-4$ will promote $\mathrm{Th}_{2}$-type responses (Romagnani, 1992).

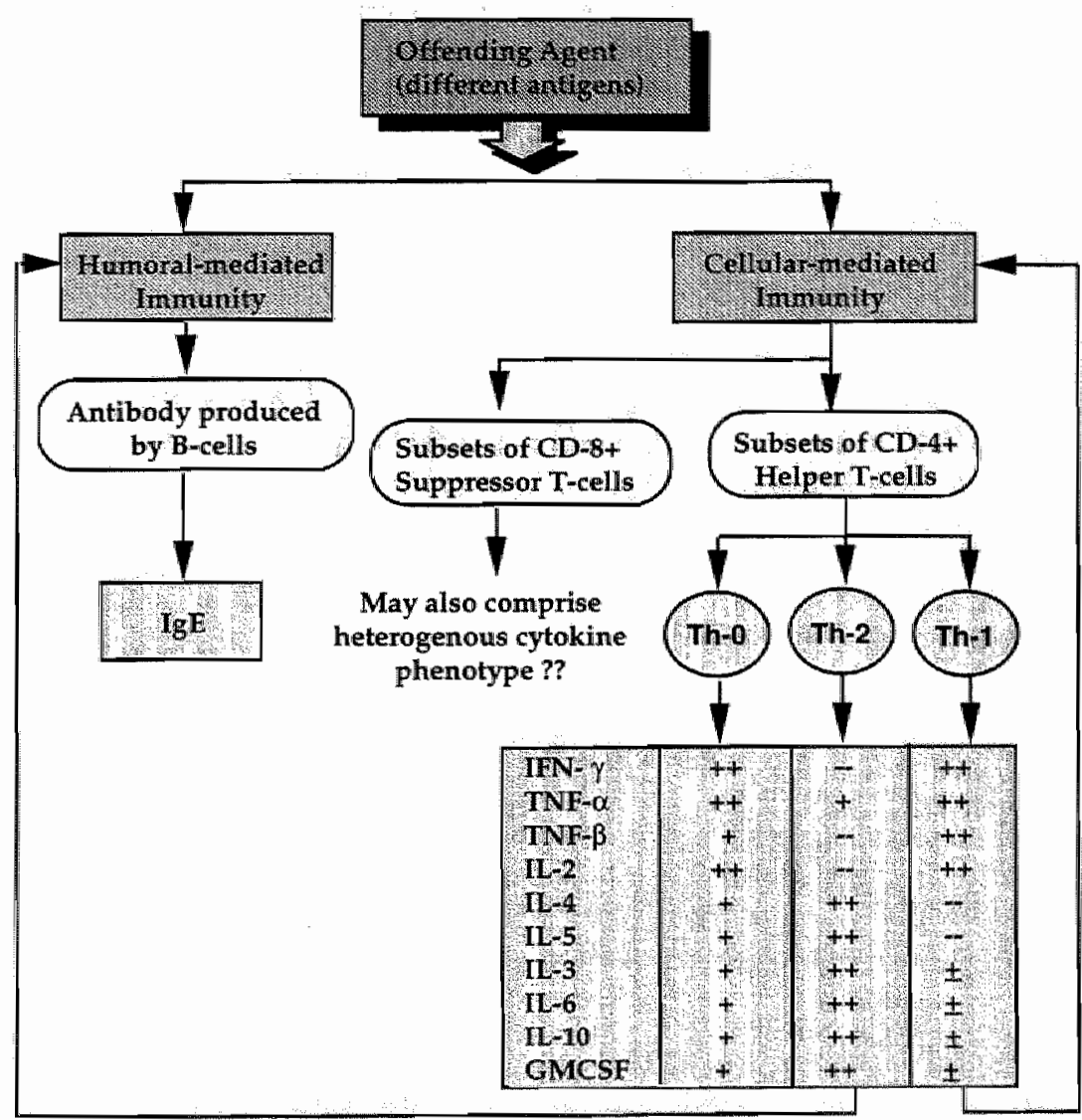

Figure 1.2. The scheme of the functional properties, mecharnism of regulation, and cytokine secretion profile of human CD4+ T cell subset (Source: Del-Prete et al., 1994)

In bronchial hyperresponsive-ness, especially increases in serum IL-4 and $\Pi \mathrm{L}-5$ and decrease in IFN- $\gamma$ have been reported. An imbalance between IL-4, IL-5. and IFN $-\gamma$ stimulates $T h_{2}$ cell proliferation, which in turn is an important hypothetical mechanism in bronchial hyperresponsive-ness and asthma (Holtzman et al., 1996). The proportion of the workers that show symptoms of asthma has a genetic (Postma et al., 1995) acquired deviation of these cytokines from normals. As a working hypothesis for this dissertation, we suggest that workers developing occupational asthma or susceptibility to this disease have different profile of IL-4, IL-5 and IFN- $\gamma$. 


\subsubsection{Chronic Obstructive Pulmonary Disease (COPD)}

The definition of COPD is an irreversible reduction in flow from the lung during a forced expiratory maneuver. Because chronic bronchitis and emphysema have been used in the literature without sufficient information provided to group subjects into diagnostic classifications, it is necessary to refer to information collected under a broad designation as COPD (Christiani, 1994). It has become apparent (Table 1.2) that the patients with COPD can present with features of both chronic bronchitis and emphysema syndromes (Stoller and Aboussouan, 1995).

Table 1.2. Clinical features of chronic obstructive pulmonary disease: distinctions between chronic bronchitis and emphysema (Source: Stoller and Aboussouan, 1995)

\begin{tabular}{|c|c|c|}
\hline Features & Chronic bronchitis & Emphysema \\
\hline $\begin{array}{l}\text { Symptoms } \\
\text { - chronic cough, phlegm } \\
\text { - cor pulmonale } \\
\text { Physiologic function } \\
\text { - Flow Volume } \\
\text { FEV }_{1} \\
\text { FEV }_{1} / \text { FVC } \\
\text { FEV }_{1} \% \\
\text { - Lung Volume } \\
\text { Residual volume } \\
\text { Total lung capacity } \\
\text { Gas exchange } \\
\text { Diffusing capacity }\end{array}$ & $\begin{array}{c}\text { Common } \\
\text { Present } \\
\text { (multiple exacerbation) } \\
\text { Decreased } \\
\text { Decreased } \\
\text { Decreased } \\
\text { Normal } \\
\text { Normal } \\
\text { Often decreased } \\
\text { Normal }\end{array}$ & $\begin{array}{c}\text { Less common } \\
\text { Present } \\
\text { (in late stage) } \\
\text { Decreased } \\
\text { Decreased } \\
\text { Decreased } \\
\text { Increased (air trapping) } \\
\text { Increased } \\
\text { Often preserved } \\
\text { Decreased }\end{array}$ \\
\hline
\end{tabular}

Although chronic bronchitis and emphysema demonstrate distinctive pathologic features and may be seen in 'pure' form, pathologic features of both entities often coexist in the same individual. This frequent overlap between chronic bronchitis and emphysema has been suggested in several different ways (Stoller and Aboussouan, 1995). First, as the extent of emphysema increases in resected paper-mounted lungs, the Reid index rises (Thurlbeck et al., 1970; Greenburg et al., 1987). Second, as the degree of emphysema increases among resected lungs, the frequency of chronic bronchitis in these patients increases. Observation by Thurlbeck suggests that among patient with postmortem evidence of severe emphysema, premortem chronic bronchitis is universally present (Thurlbeck, 1976). Finally, among patients satisfying the clinical definition of chronic bronchitis, emphysema of at least $25 \%$ of the examined lung was 6 times more prevalent ( $72 \%$ of chronic bronchitis) than in nonbronchitic patients (Mitchell et al., 1966). 


\subsubsection{Chronic Bronchitis}

Chronic bronchitis was defined by the Ciba Guest Symposium in 1959 as a condition of chronic or recurrent excess of mucus secretion in the bronchial tree. The British Medical Research Council defined 'chronic' as meaning "occurring in most days for at least three months in the year for at least two successive years". Its clinical definition adds a third criterion: dyspnea and/or airflow limitation. This implied persistent production of sputum, expectorated or swallowed, which might or might not be associated with cough. Hypersecretion of mucus is produced both by mucous glands and goblet cells. The mucous glands are enlarged due to hyperplasia of their cells and engagement with mucus number. Enlargement of the glands is conveniently quantified by the ratio of gland-towall thickness which is known as the Reid Index. The average value of the index in normal lungs is 0.26; in those with chronic bronchitis is 0.59 (Reid, 1960; 1967). These findings correlate with dyspnea and significant respiratory function impairment. A linear dose-response relationship between the production of sputum and pack-years of smoking was demonstrated by Cullian (1991); however, using matched-pair analysis, he found no significant association with occupational exposure to respirable dusts, fumes and gases, although an exposure-response was apparent. Fletcher and Peto (1977) concluded that neither chronic expectoration nor associated bronchial infection are related causaliy to the development of airflow obstruction and that production of sputum and obstruction of airflow are relatively independent responses to cigarette smoke occurring together due to the common factor of smoking. Until recently, a diagnosis of bronchitis implied a condition characterized by cough and sputum, and one usually associated with a reduction in ventilatory capacity or likely to lead to such a reduction.

The standard questionnaire for the diagnosis of chronic bronchitis proposed by the British Medical Research Council in 1960, and modified in 1986 to include other respiratory symptoms, has been widely employed for the assessment of prevalence. When used, other causes of chronic production of sputum and of cough must be excluded (Parkes, 1994).

Forced Expiratory Volume in 1 second $\left(\mathrm{FEV}_{1}\right)$ is now a commonly used measure of airway obstruction in such epidemiological studies. It undergoes a slow decline with increasing age (about $20-30 \mathrm{ml} /$ year) in most normal adults without the development of dyspnea. But the effect of smoking in FEV 1 over the years is complex (Fletcher and Peto, 1977). The majority of smokers have either a normal or an increased decline of $\mathrm{FEV}_{1}$, without disabling airflow obstruction. In the remaining, however, the decline is more rapid $(60-80 \mathrm{ml} /$ year $)$ and results in disabling airflow obstruction in about the sixth decade (Speizer and Tager, 1979). If smoking is stopped, the progressive fall in $\mathrm{FEV}_{1}$ ceases in most instances, but in many of those with respiratory disability it continues until death from respiratory failure, or until pulmonary heart disease. The reason for the differences in individual responses (or susceptibility), especially in advanced disease, is not understood (Traver et al., 1979). Hereditary factors and smoking probably contribute about equally to the likelihood of developing significant airflow obstruction, and a family history of allergy appears to be significantly more common among smokers with a rapid decline in $\mathrm{FEV}_{1}$ compared with smokers with a slow annual decline (Taylor 1985). 
The pathogenesis of chronic bronchitis is still not entirely clear. It has been proposed that initially an (genetic and/or environmental) impairment of mucus clearance allows microorganisms and/or other offending agents to persist sufficiently long in the bronchial tree to establish themselves and produce endotoxin (Cole and Wilson, 1989). Their persistence could stimulate an inflammatory response, leading to a "vicious circle' of events. Part of this inflammatory response is a considerable traffic of neutrophils to the lumen of the affected bronchial tree, rarely being found in healthy bronchial tissue or lumen. Because of their potential for damaging tissue, these neutrophils may be the most significant component of the inflammatory response.

The neutrophil influx is probably initiated by chemoattractant factors, which may be of bacterial or host origin (Ras et al, 1990; Colditz and Morley, 1991). Persistence of bacterial infection or other offending agents (Figure 1.3) can induce IL- 1 and TNF- $\alpha$ release from many cells such as alveolar macrophages, epithelial cells, endothelial cells, fibroblasts and PMNs; moreover, these cytokines stimulate expression of ICAM-1 and the CD11/CD18 integrin complex involved in a variety of cell adherence function, including migration of neutrophils from endothelium into tissue and bronchial lumen (Schuimaar et al., 1991). They also induce the production of IL- 8 , which itself is a powerful mediator of neutrophil transmigration and activation. (Djeu et al., 1990). IL-8 has been shown to be present systemically in sepsis (Hack et al., 1992) and is thought to play a role in the development of chronic pulmonary disease.

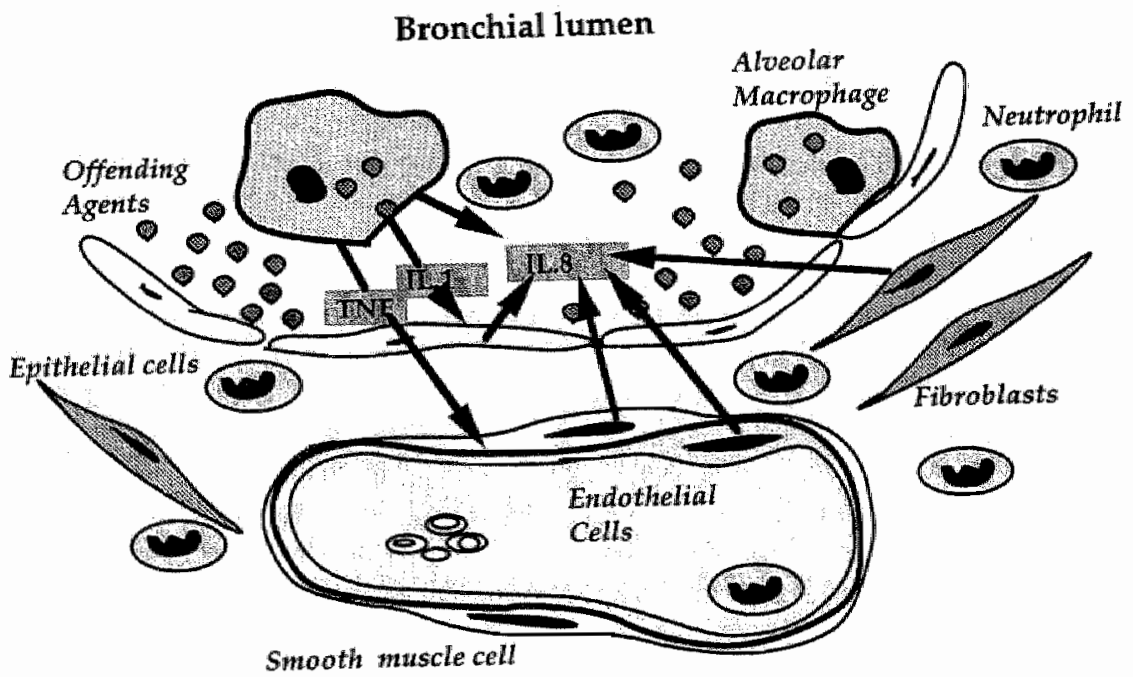

Figure 1.3. The schentatic of the developing inflammatory response in the lung

The aloedar macrophage and epithelial cells are the first cells encountered by the offending agents, such as bacteria or dust particles, and become actioated. The activated alveolar macrophage would produce TNF- $\alpha$ and IL-1 which stimulate epithelial cells, fibroblasts, macrophages, and endothelial cells to produce IL-8, culminating in the recruitment of neutrophils into the bronchial lumen and the parenchyme of the lung (Source: Strieter et al., 1993). 
The finding of IL-1 and TNF- $\alpha$ together with a very high level of IL- 8 in the expectorated secretion of patient with COPD but not asthma is consistent with the chemoattractant of considerable number of neutrophils to the bronchial lumen from which these secretions derive (Eller et al, 1994; Keatings et al., 1996). Inflammation of the central airways is a prominent feature in subjects with chronic bronchitis. The pathology of chronic bronchitis includes an inflammatory mononuclear infiltrate in the airway wall and a neutrophil influx into the airway lumen, that produce the inflammation and induce mucus hypersecretion. There is growing evidence incriminating neutrophil and lymphocytes constituents in the initiation and maintenance of cough and mucus expectoration that occurs in subjects with chronic bronchitis (Hoidal, 1994). The working hypothesis derived from these data is that increased $\mathrm{LL}-8$ secretion might be a marker of early symptoms of bronchitis in workers exposed to chemicals.

\subsubsection{Emphysema}

Emphysema is a condition of the lung characterized by abnormal, permanent enlargement of the airspace distal to the terminal bronchiole, accompanied by destruction of their walls, and without obvious fibrosis (Snider et al., 1985; American Thoracic Society, 1987). Occupational exposures that are believed to cause emphysema are few and not always well authenticated. Clinical, physiological and radiographic findings are insensitive and imprecise in detecting and quantifying emphysema, the only sure method is inspection of properly prepared lungs. Therefore, emphysema is the best defined and described morphologically.

Disruption of the network of elastic fibers in the lungs is generally held to be a cardinal factor in the production of emphysema. It is well known association of an inherited deficiency of a protease (elastase)-inhibiting serum protein, $\alpha-1$ antitrypsin ( $\alpha-1-\mathrm{AT})$, with rapidly advancing emphysema in some individuals (Laurell and Ericksson, 1963). The current hypothesis proposes the balance between elastase activity and its inhibition is altered in cigarette smokers so that part of the lung is essentially autodigested, with the production of emphysema (Christiani, 1994).

Although emphysema is an anatomic diagnosis, the disease can be detected without tissue in the clinical examination. Radiographic features together with increased lung volumes (Total Lung Capacity, Vital Capacity), usually with decreased diffusion capacity (DLCO) are currently utilized as acceptable criteria with which to distinguish the emphysema component in subjects with obstructive airway disease. Recently, Watanuki et al. (1994) claim that mean attenuation value (MAV) and relative area of emphysema obtained from computed tomography (CT) density measurements accurately assess the severity of emphysema in patients with COPD as well as selective alveolobronchograms ( $\mathrm{SAB}$ ). 


\subsection{Assessment of Chronic Non-specific Airway Diseases}

Since the target tissue is not measurable in practice, the use of different tools reflecting what is happening in the lung such as the questionnaire, lung function measurements, chest $X$-ray, cells and mediators in bronchoalveolar lavage, nasal lavage, and blood are very important. This chapter reviews the methodology to detect chronic non-specific airway diseases, especially occupational asthma and chronic bronchitis.

\subsubsection{Questionnaire}

A questionnaire on respiratory symptoms should be included in any survey of persons who may have breathlessness, bronchitis or asthma. The Medical Research Council (MRC) questionnaire (Medical Research Council, 1976) is usually employed and for this purpose has been translated into over 10 languages. The questionnaire consists of the preamble, questions on respiratory complaints such as cough and phlegm, breathlessness, past illnesses, and smoking. The interviewer should use the questions as printed and ask them in a clear even voice which is only raised to emphasize the words in the questions which are printed in heavy type including 'Yes' or ' $\mathrm{No}^{\prime}$. The questions used to determine respiratory symptoms are listed in table 1.3 below.

Table 1.3. The questions of Medical Research Council (MRC) questionnaire used to determine respiratory symptoms of chronic non-specific airway diseases

1. Do you cough usually in the morning during the winter season?

2. Do you cough usually during day time or at night during the winter season?

3. Do you cough on most days for at least 3 months a year?

5. Do you cough up phlegms usually in the morning during the winter season? 6. Do you cough up phlegms usually during day-time or at night during the
winter season?

11. Have you ever been troubled by shortmess of breath when walking fast on the flat ground or climbing an undemanding hill or climbing the stairs?

16. Has your chest ever sounded wheezy?

18. Do you ever had attacks of shortness of breath with wheeze?

Defintion of complaints:
a. Cough
b. Phlegm
c. Shortness of breath
d. Wheezing
: 'Yes' answered to questions 1 and/or 2
: 'Yes' answered to questions 5 and/or 6
: 'Yes" answered to question 11
: 'Yes' answered to question 16

Definition of respiratory symptoms :

- Bronchitis

- Chronic bronchitis

- Asthma

- Asthma attack

"Yes" for a and b

: 'Yes' for $a$ and $b_{\text {r }}$ and ' $Y$ ' $Y$ ' answered to question 3

: "Yes" for $c$ and $d$

: 'Yes' for c and $\mathrm{d}$, and 'Yes' answered to question 18 


\subsubsection{Lung Function Measurements}

Two tests of lung function are commonly used to assess the functional state of the lung in occupational conditions, namely spirometry (flow volume curve) and the forced oscillation technique (FOT). Spirometry measures the rate and extent to which air can be moved in and out of the lung. The subject is asked to take a deepest inspiration and then to breathe out as fast and completely as possible. Air movements are recorded as the maximal flow volume curve of the lung by a spirometer. Three recordings of forced vital capacity within $5 \%$ or a 100 $\mathrm{ml}$ range are obtained from each subject. Parameters derived from the flow volume curves are: forced vital capacity (FVC), forced expiratory volume in 1 second $\left(\mathrm{FEV}_{1}\right), \mathrm{FEV}_{1} / \mathrm{FVC}$ ratio, peak expiratory flow volume (PEF), and maximal mid expiratory flow volume (MMEF). The main advantages of flow volume curves are that they have been applied uniformly all over the world and all flow volume values are related to the reference values that are adjusted for confounders like gender, age, weight and height (Quanjer, 1983) for individual diagnosis. Values of two or more standard deviations below the reference value (i.e. a value less than $80 \%$ of the standard value) of $\mathrm{FEV}_{1}$ reflect airway obstruction. While MMEF is used to detect small airway obstruction. The main disadvantages is that these measurements depend on forced expiratory flow maneuvers and therefore on patient compliance. To achieve maximal patient compliance, the test needs to be performed by experience personnel which is not always present in occupational settings.

The forced oscillation technique (FOT) was first introduced by Dubois et al in 1956. The technique requires no special cooperation from the subject, who is allowed to breathe freely. FOT measures the resistance and reactance of the respiratory system simultaneously at various fixed frequencies (between $4-52 \mathrm{~Hz}$ ) by means of a pseudo-random noise pressure signal superimposed at the mouth during spontaneous quiet breathing. The technique was originally described by Làndsér et al. (1976), the seated subject supports the cheeks and the floor of the mouth with his/her hands and breathes quietly via a screen pneumotachograph through a high impedance side tube. The pseudo-random noise impulse is generated by an oscillator, amplified and transmitted by a loudspeaker. Pressure and flow signals are fed directly without filtering into a Fourier analyzing system, dividing pressure by flow: the system calculates an impedance value for each of the investigated frequencies. To filter out the disturbing signals produced by the breathing of the subject, an ensemble averaging is performed during 8 seconds. Accordingly, the obtained impedance values are averaged over the same period, covering several breathing cycles. The impedance is partitioned into a real (resistance) and an imaginary (reactance) part. Of the obtained impedance data, the resistance at $8 \mathrm{~Hz}(\mathrm{R} 8)$, at $28 \mathrm{~Hz}(\mathrm{R} 28)$, the difference between $\mathrm{R} 28$ and $\mathrm{R} 8$ (frequency dependence (FD), signifying the course of the resistance versus frequency curve), the reactance at $8 \mathrm{~Hz}(X 8)$ and the resonant frequency $\left(f_{0}\right)$ are used for analysis. R8 is chosen because at this frequency usually coherence function $>0.95$ is obtained, which is not always obtained at lower frequencies. A negative $F D$ and a resonance frequency $\left(f_{0}\right)$ exceeding $15 \mathrm{~Hz}$ are regarded as indicative for airflow limitation. 
Summarizing data on airway obstruction in male workers from different surveys shows that the total average prevalence of FEV $_{1}<80 \%$ is $8.1 \%$ which is in line to that is found by FOT criteria (a negative FD and a resonance frequency $\left(\mathrm{f}_{0}\right)$ exceeding $15 \mathrm{~Hz}$ ) $10.4 \%$. Age seems to be no major descriptor of the observed differences between groups (Table 1.4). Differences in impedance patterns and prevalence of airway obstruction are demonstrated after inorganic or organic dust exposure. In workers exposed to inorganic diatomaceous dust a parallel increase of resistance over all frequencies was observed compared to controls, suggesting an obstruction in the upper airways (Van Noord et al., 1989). Prevalence of airway obstruction was largely the same either using FEV $(8.8 \%)$ or FOT $(9.8 \%)$. On the other hand, in grain workers an asthmatic-like pattern of impedance was observed (Jorna, 1994), i.e. a frequency dependence of resistance in the range of $8-28 \mathrm{~Hz}$ and concurrently a decrease of reactance, suggesting an airway obstruction extending to the peripheral airways (Wouters, 1990). This time prevalence is much higher using FOT $(14.9 \%)$ versus FEV $_{1}(3.1 \%)$ criteria.

Table 1.4. Prevalence of airflow obstruction in the populations of male workers studied in cross-sectional studies (Source: Jorna, 1994)

\begin{tabular}{|c|c|c|c|c|c|c|c|}
\hline \multirow[t]{2}{*}{ Population } & \multicolumn{3}{|c|}{$\begin{array}{l}\text { All workers } \\
\% \text { Obstruction }\end{array}$} & \multicolumn{4}{|c|}{$\begin{array}{l}\text { Exposed workers } \\
\% \text { Obstruction } *\end{array}$} \\
\hline & $\mathbf{n}$ & $\mathrm{FEV}_{1}$ & FOT & 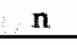 & Age & $\mathrm{FEV}_{1}$ & FOT \\
\hline $\begin{array}{l}\text { Coal miners } \\
\text { Potato sorters } \\
\text { Grain workers } \\
\text { Chemical workers }\end{array}$ & $\begin{array}{l}102 \\
172 \\
194 \\
145 \\
\end{array}$ & $\begin{array}{c}8.8 \\
13.4 \\
3.1 \\
8.3 \\
\end{array}$ & $\begin{array}{l}9.8 \\
8.7 \\
14.9 \\
6.9 \\
\end{array}$ & $\begin{array}{l}102 \\
117 \\
139 \\
145 \\
\end{array}$ & $\begin{array}{l}49.4 \\
46.4 \\
42.3 \\
38.8 \\
\end{array}$ & $\begin{array}{r}8.8 \\
13.4 \\
2.8 \\
8.3 \\
\end{array}$ & $\begin{array}{r}9.8 \\
8.5 \\
18.7 \\
6.3 \\
\end{array}$ \\
\hline Tottal & 613 & 8.1 & 10.4 & 504 & 43.6 & 8.1 & 11.1 \\
\hline
\end{tabular}

* Criteria for airway obstruction is $F E V_{1}<80 \%$ for spirometry; $F_{0}>15 \mathrm{~Hz}$ and $F D<0$ for $F O T$.

\subsubsection{Radiographic Techniques}

Chest radiography is performed for both clinical and epidemiological purposes to establish diagnosis, prevalence, behaviour, and prognosis in patients or in different occupational communities. Chest $X$-ray is without doubt the most informative investigation for pneumoconiosis, beside analysis of occupational history, physical examination, and lung function test. Conventionally, the standard chest radiograph is $17 \times 14$ inches $(43 \times 35 \mathrm{~cm})$ and a postero-anterior (PA) view. During X-ray exposure, the subject must be in the deepest possible inspiration. There is no unique radiographic appearance for any one type of pneumoconiosis. The diagnosis must be deductive in the light of all other relevant data, such as the results of occupational history, respiratory symptoms, physical examination, previous X-ray film for comparison, and also a clear understanding of the time scale involved in the progression of pneumoconiosis (Bretland, 1994). The most recently (1980) of the International Labour Office (ILO) criteria has been universally adopted (Parkes, 1994). 
There are two methods of reading serial films for identification and assessment of progression of disease. The first the films of each are inspected 'side by side' in chronological order. The second, they are separated and shuffled in with those of all subjects in the group being studied, thus producing a random collection of films. It is often urged, that the independent randomized method results in less bias in interpretation of progression or regression. However, it has been convincingly shown that there is substantially less error when films are viewed together by the side-by-side method and read in known temporal order (Liddell and Morgan, 1978).

Although the quality of the image of computed tomography (CT) has improved, it cannot replace chest radiology for the first-line investigation of disease of the chest, especially suspected occupational lung disease. It is generally accepted that CT is the best investigation for mediastinal vascular structure and masses (Husband and Fry, 1981) and especially for suspected disease of the lymph nodes (Sagel and Aronberg, 1982). Whereas peripheral lung disease, especially widespread pathology in which the visualization of small lesion in the size of 1 to $3 \mathrm{~mm}$ range is essential to the diagnosis, presents some difficulties. Although CT cannot compete with chest radiography in detail and sharpness, it can compensate for this by better contrast resolution and it can show the anatomy and pathology from another angle by producing an image of a transverse slice.

\subsubsection{Brochoalveolar Lavage}

Since its introduction into clinical investigation in the $1970 \mathrm{~s}$, the technique of small-volume, segmental bronchoalveolar lavage (BAL), via the fibre optic bronchoscope, has generated considerable information on inflammatory cells and other components washed from the airspaces of the lung of patients with a wide range of diffuse lung diseases. It is important to follow a standardized procedure: standardized introduction wolume of lavage fluid, sterile physiological saline, maximum of $300 \mathrm{ml}$, employing 50 or $60 \mathrm{ml}$ introduction aliquots or minimum of $100 \mathrm{ml}$, employing $20 \mathrm{ml}$ introduction aliquots, and also use a standardized site for lavage, usually the right middle lobe or the lateral segment of the right lower lobe (Klech and Pohl, 1989; BAL Cooperative Group Steering Committee, 1990). Apart from making an important contribution to studies of pathogenic mechanisms, some of the information generated by BAL has proved of value as an aid to differential diagnosis of these diseases and, as a consequence, $\mathrm{BAL}$ is a minimally invasive procedure which involves only a simple addition to routine fibre optic bronchoscopy and now is widely included as part of routine clinical investigation (Haslam, 1994). However, this procedure needs some preparations and should be performed in hospital. BAL is a useful method complementary to lung biopsy, because it provides information on pooled inflammatory cells and other components washed from the airspaces of a relatively large segment of the lungs, which can be advantageous if the disease is patchy.

The fluid samples obtained by BAL contain a wide range of components, including immune and inflammatory cells, and a wide variety of soluble extracellular components, including protein derived from the serum, enzyme inhibitors, cytokines, and many other components including the phospholipids 
and apoproteins which make up the pulmonary surfactant system and immunoglobulins. Occasionally, additional components may also be present, for example, inorganic dust particles or micro organisms indicating a specific exposure or infection. The reported average total cell count for normal, healthy, thonsmoking young adult is 100,000 cells $/ \mathrm{ml}$, and for normal smokers is higher, 400,000 cells / ml (Reynolds and Newball, 1974; Hunninghake et al., 1979). The difference between smokers and non-smokers is detectable but is less in patients with interstitial lung disease, presumably due to super-imposed disease-related inflammatory cell increase. The cell counts can give an indication of overall cellularity, but the interpretation is difficult because it is not technically possible to standardize both the lavage fluid introduction and recovery volumes. However, the differential percentage counts of the cell types in BAL have proved of greater value in routine clinical investigation (Reynolds and Newball, 1974; Klech and Pohl, 1989; BAL co-operative Group Steering Committee, 1990). Ciliated or squamous epithelial cells from the bronchi may also be present. When they exceed $5 \%$ this suggests the presence of bronchial inflammation, which needs to be taken into account when interpreting the lavage result (Haslam, 1984). Although useful, the trends of differences in BAL cell counts are not sufficient by themselves to establish a diagnosis due to the overlap which occurs between the disorders, and to the variability between individuals (Haslam, 1994). Neutrophils are the inflammatory cell type most often increased in interstitial lung fibrosis such as the inorganic dust diseases of asbestosis and silicosis (Rom et al., 1987; Wallaert et al., 1990).

\subsubsection{Nasal Lavage}

The nose is the primary portal of entry for inspired air in humans, and therefore it is the first region of the respiratory tract that is in contact with airborne pollutants. If this pollutant is a water soluble, respiratory irritant capable of causing cellular damage, then effects should be detected in the nasal passages. Since many of the cell types found in the nasopharyngeal region are the same or similar to cells found in the trachea or bronchi, the responses of nasal cells to respiratory irritants may be similar to the response of airways and alveolar cells. We can learn about inflammatory mechanisms by studying the readily accessible human nasal mucosa rather than the relatively inaccessible bronchial mucosa. Lymphocytes, eosinophils, mast cells, many other migrating cells and the epithellal lining cells in the airway have the capacity to produce and release different mediators and enzymes as well as cytokines. Much of the current research in rhinitis and asthma is focused on cellular changes in biopsy material and lavage fluid. These materials are analyzed by molecular biology techniques and are well suited for showing similarities between the nasal and bronchial mucosa. Safe nasal challenges and examination of inflammatory mucosal indices should be useful in studies of occupational asthma, which often is preceded by or associated with occupational rhinitis (Persson et al., 1992).

Plasma extravasation from the profuse subepithelial micro vessel and the subsequent exudation of plasma across the mucosa into the lumen of upper airway is not just an exaggeration of the normal baseline exchange of fluid and solutes between the capillary circulation and the mucosa (Erjefalt and Persson, 
1989). Plasma exudation seems to be a specific inflammatory response in human airways. It is also a general response in the sense that it occurs regardless of which cellular or non-cellular mechanism drives the inflammation. Therefore, mucosal exudation of plasma reflects equally the inflammatory airway response in allergy and in infection. Moreover " plasma exudation is not only reflecting the intensity of inflammation but also contributing to the vicious circles and sequelae of airway inflammation (Persson et al., 1992).

Table 1.5. Review of several studies on inflammatory markers in nasal lavage fluid

\begin{tabular}{|c|c|c|c|}
\hline Exposure & Markers & Results & Reference \\
\hline $\begin{array}{l}\text { Ozone }: 0.4 \mathrm{ppm} \\
86-230 \mu \mathrm{g} / \mathrm{m}^{3} \\
0.4 \mathrm{ppm}\end{array}$ & $\begin{array}{l}\text { PMNs, Cells } \\
\text { MPO, ECP } \\
\text { Tryptase, IL-6 } \\
\text { Albumine } \\
\text { Uric acid } \\
\text { Urea }\end{array}$ & $\begin{array}{l}\text { increased } \\
\text { increased } \\
\text { increased } \\
\text { increased } \\
\text { increased } \\
\text { increased }\end{array}$ & $\begin{array}{l}\text { Koren et al., } 1989 \\
\text { Fischer et al., } 1993 \\
\\
\text { Devlin et al., } 1994 \\
\text { Graham and Koren, } \\
1990\end{array}$ \\
\hline $\begin{array}{l}\text { Formaldehyde } \\
0.5 \mathrm{mg} / \mathrm{m}^{3}\end{array}$ & $\begin{array}{l}\text { Eosinophils } \\
\text { Albumine } \\
\text { Total protein }\end{array}$ & $\begin{array}{l}\text { increased }(\mathrm{p}<0.05) \\
\text { increased }(\mathrm{p}<0.05) \\
\text { increased }(\mathrm{p}<0.05)\end{array}$ & Pazdrak et al., 1993 \\
\hline Asthmatic Children & $\overline{\mathrm{IL}}-8, \mathrm{ECP}$ & increased $(\mathrm{p}<0.05)$ & Noah et al., 1995a \\
\hline $\begin{array}{l}\text { Wood dust } \\
0.12-1.18 \mathrm{mg} / \mathrm{m}^{3}\end{array}$ & Nasal symptoms & increased $(\mathrm{p}<0.01)$ & Ahman et al., 1995 \\
\hline $\begin{array}{l}\text { Diesel exhaust particles } \\
0.15 \mathrm{mg} \text { DEPs suspended } \\
\text { in } 200 \mu \mathrm{l} \text { of saline sol. }\end{array}$ & $\begin{array}{l}\text { IL-2, IL-4 } \\
\text { IL-5, IL-6 } \\
\text { IL-10, IL-13 } \\
\text { IFN- } \gamma \\
\text { IgE }\end{array}$ & $\begin{array}{l}\text { increased } \\
\text { increased } \\
\text { increased } \\
\text { increased } \\
\text { increased }(p<0.01)\end{array}$ & $\begin{array}{l}\text { Diaz-Sanchez et al., } \\
1996\end{array}$ \\
\hline $\begin{array}{l}\text { Grain dust } \\
\text { Total dust }=6.8 \mathrm{mg} / \mathrm{m}^{3} \\
\text { Endotoxin }=2372 \mathrm{EU} / \mathrm{m}^{3}\end{array}$ & $\begin{array}{l}\text { Total cells } \\
\text { PMNs }\end{array}$ & $\begin{array}{l}\text { Higher than control } \\
\text { Higher than control } \\
\text { (both } p<0.05 \text { ) }\end{array}$ & Blaski et al., 1996 \\
\hline $\begin{array}{l}\text { Swine dust } \\
20.5 \mathrm{mg} / \mathrm{m}^{3} \text { Dust } \\
1.2 \mu \mathrm{g} / \mathrm{m}^{3} \text { Endotoxin }\end{array}$ & $\begin{array}{l}\text { PMNs } \\
\text { IL-1, IL-1 } \\
\text { IL-6, TNF- } \alpha\end{array}$ & $\begin{array}{l}\text { increased } 40 \text { fold } \\
\text { increased }(p<0.01) \\
\text { increased }(p<0.01)\end{array}$ & Wang et al., 1997 \\
\hline $\begin{array}{l}\text { Viral Acute Upper } \\
\text { Respiratory Infection }\end{array}$ & $\begin{array}{l}\text { Cells and PMNs } \\
\text { IL- } 1 \text {, IL- } 6 \text {, } \\
\text { IL- } 8 \text { and TNF- } \alpha\end{array}$ & $\begin{array}{l}\text { increased }(p<0.01) \\
\text { increased }(p<0.01)\end{array}$ & Noah èt al." $1995 \mathrm{~b}$ \\
\hline
\end{tabular}

Abbreviations: $P M N s=$ Polymorphonuclear cells; $M P O=$ Myeloperoxidase; $E C P=$ Easinophil CathionicProtein. 
Nasal lavage (NAL) is a simple and economical method to perform, relatively non-invasive, and allows multiple sequential sampling of both nasal secretion and cells from the same subject. The technique was first described by Graham and Koren (1990) as follows: the subject in sitting position, lift his neck approximately $45^{\circ}$ backward and elevate the palate to close his nasopharynx. Five $\mathrm{ml}$ of room temperature sterile phosphate buffered saline solution $(0.9 \%) \mathrm{Ca}^{2+}$ and $\mathrm{Mg}^{2+}$ free is instilled into each nostril with a $10 \mathrm{ml}$ sterile polysterene pipet, while the subject is not breath or swallow. After 10 seconds, the subject put his head forward and the nasal lavage fluid is spelled into a $15 \mathrm{ml}$ centrifuge tube via a polyamide gauze filtered funnel to separate mucous. The NAL procedure is so easy that it can be carried out by the patient or volunteer after minimal training and conveniently sampled even at home and/or at work. It is of a non-traumatic nature and does not call for any local anaesthetic or other form of premedication; the airway specificity, the qualitative recovery, the unlimited repeatibility, and the safety distinguish NAL from BAL (Greiff et al., 1990; Walters and Gardiner, 1991).

NAL has been used to study antioxidant status of the upper respiratory tract (Kelly et al., 1996), mediators produced in human exposed to ozone (Graham and Koren, 1990; Fischer et al., 1993; Devlin et al., 1994; Steerenberg et al., 1996), cytopathology of of the nasal mucosa of humans exposed to diesel engine exhaust (Diaz-Sanzes et al., 1996), and swine dust (Wang et al., 1997). These studies (see also Table 1.5) clearly showed the utility of this technique in various settings. There is a possibility that the non-invasive NAL procedure can be used as a surrogate for the more costly and invasive broncho-alveolar lavage (BAL) procedure in epidemiological studies. It should be considering that mucosal inflammatory responses in the tracheobronchial airways agree better with nasal mucosa responses than with responses occurring in the terminal airways and parenchymal region as shown by bronchoalveolar lavage material (Persson et al., 1992).

\subsubsection{Whole Blood and Serum Cytokine Assays}

Whole blood assays have been introduced to determine the ex-vioo kinetic of cytokine productions, as well as to facilitate (and minimize artificial effects of) sample processing (Desch et al., 1989; Strieter et al., 1990). Recently Nerad et al. (1992) have reported a simplified method to determine the production of interleukin-1 (IL-1), the IL-1 receptor antagonist and TNF in whole blood. Sample processing should be performed as soon as possible (within 30 minutes) after blood collection. This method allows the determination ofe $x$ vivo cytokine productions to be used in surveys and routine screening in occupational settings which have limited laboratory facilities (Schins et al., 1996).

The whole blood assay (Figure 1.4) was described previously Nerad et al. (1992) and modified by Schins et al. (1996). Briefly, two $1 \mathrm{ml}$ portions of the heparinized blood $(10 \mathrm{ml})$ are transferred into 2 vacuum reagent tubes containing $1 \mathrm{ml}$ RPMI culture medium (GIBCO Life, Paisley UK) for spontaneous blood cytokine release. The duplicate test tubes are incubated in a shaking water bath 40 times per minute at $37^{\circ} \mathrm{C}$, under an angle of $45^{\circ}$. After 4 hours, all tubes are placed on ice water and after another 3 minutes, all tubes are centrifuged (600 
$\mathrm{g}, 4^{\circ} \mathrm{C}, 5 \mathrm{~min}$ ) and placed on ice water before transfer the supernatants into micronics $3 \times 250 \mu \mathrm{l}$, and stored immediately at $-20^{\circ} \mathrm{C}$ until analysis. Blood can be incubated without any stimulants to measure-spontaneous release of specific cytokines or with stimulants such as lipopolysaccharide (LPS) to measure the capacity producing specific cytokines in response to a certain stimulant.

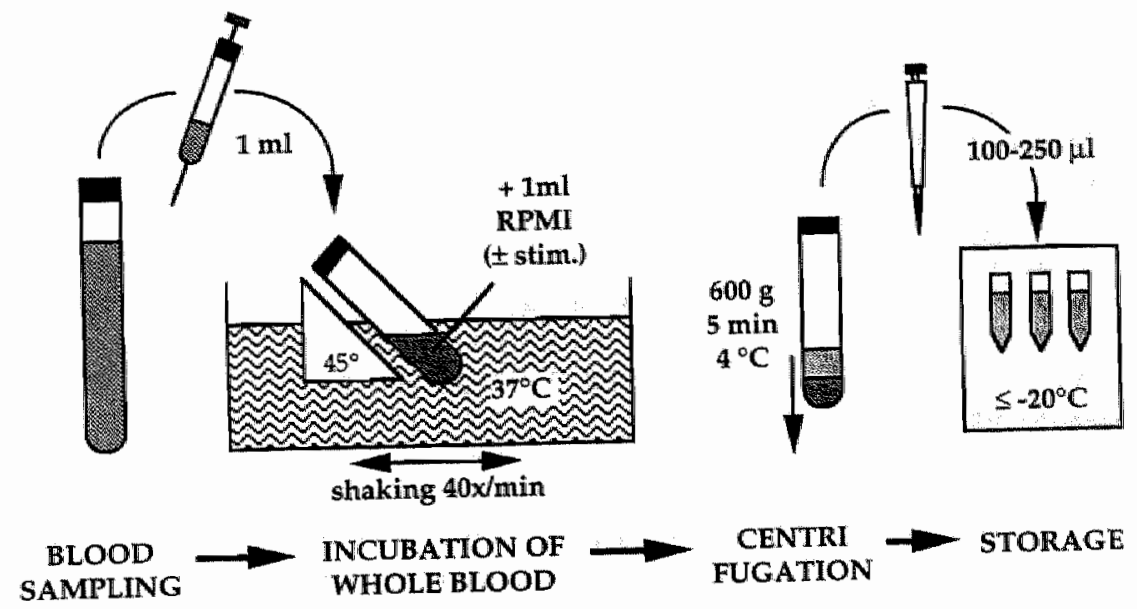

Figure 1.4. Scheme of whole blood assay of cytokines (Schins et al., 1996)

Blood cytokine releases are determined using specific enzyme-linked immunoabsorbent assay (ELISA) as described previously by Leeuwenberg et al. (1994) and Borm et al (1996). Briefly, the day before, plate was coated with monoclonal antibody $3 \mathrm{H} 7$ [1:500 in sterile PBS (10 ml/plate: $20 \mu \mathrm{l})] 100 \mu \mathrm{l} /$ well. Overnight incubation by $4{ }^{\circ} \mathrm{C}$ with cap. Flick contents into sink, hold plate upside down and blot any additional fluid onto a tissue. Saturate empty binding sites with phosphate buffer solution (PBS) $/ 1 \%$ bovine serum albumin (BSA) sterile, $150 \mu \mathrm{l} /$ well $(15 \mathrm{ml} /$ plate). Incubate the plate 1 hour at room temperature. Meanwhile dilute sample (depending on experimental conditions). Rinse plate $3 x$ with washing buffer (PBS, 0.1\% TWEEN), blot plate on tissue. Let it standing in 1 minute. Standard and samples are made as next scheme : $100 \mu \mathrm{l}$ per well. Standard (type $2 \mathrm{n}$ dilution): for example $1.00-0.50-0.25-0.125$ - etc. The plate is washed with washing buffer and let it standing 1 minute, three times. Put $100 \mu \mathrm{l}$ RaHIL-8 (Rabbit antibody for Human IL-8) biotine (1:1000 in B; 10ml/plate, so that is $10 \mu \mathrm{l})$ on each well. Incubate the plate 1 hour at room temperature. The plate is washed again with washing buffer 3 times and let it standing 1 minute. Put $100 \mu \mathrm{l}$ Streptavidine Peroxidase $(1: 4000 \mathrm{in} \mathrm{B;} 10 \mathrm{ml} /$ plate, thus $2.5 \mu \mathrm{l})$ on each well. Incubate the plate 1 hour at room temperature. The plate is washed again with washing buffer 5 times and let it standing 1 minute. Put $100 \mu l$ tetra methyl benzidine (TMB) substrate on each well $(10 \mathrm{ml} / \mathrm{plate})$. Stop the color reaction when the blue color is good or dark enough (10-20 minutes) with $0.5 \mathrm{M} \mathrm{H}_{2} \mathrm{SO}_{4}$ (Sulfuric acid), $100 \mu \mathrm{l} /$ well. Read the absorbtion with the microtiter-reader, 450 $\mathrm{nm}$. 
Serum cytokine levels are determined using chemiluminescence ELISA as described previously by Tollerud et al. (1994). Briefly, purified anti-cytokine capture (coating) monoclonal antibody $(\mathrm{mAb})$ for each cytokine was diluted in coating buffer $\left(0.1 \mathrm{M} \mathrm{NaHCO}_{3}, \mathrm{pH} 8.2\right)$, and $100 \mu \mathrm{l}$ are added to each well of a 96well flat bottom opaque microtiter immunoassay plate (Microlite 1, Dynatec Laboratories, Inc., Chantly, VA). Each plate covered, shaken gently for 30 minutes at room temperature, then incubated overnight at $4{ }^{\circ} \mathrm{C}$. Plates are washed with PBS-Tween, blotted dry, and each well blocked with $200 \mu \mathrm{l} /$ well of $2.5 \%$ (weight/volume) BSA/PBS Tween. After incubation at room temperature for 2 hours with gently shaking, plates are washed with PBS-Tween, and blotted dry. Serum samples are diluted 1:4 with $1.0 \%$ BSA/PBS-Tween. $100 \mu \mathrm{l} /$ well of diluted serum or recombinant human cytokine standard are added in triplicate wells. Plates are covered, gently shaken for 30 minutes, and incubated overnight at $4{ }^{\circ} \mathrm{C}$. After incubation, each plate is washed with PBS-Tween, and biotinylated anticytokine detecting $\mathrm{mAb}$ in $0.5 \% \mathrm{BSA} / \mathrm{PBS}$-Tween is added to each well. Each plate is incubated for 1 hour with gentle shaking, washed, and Extr Avidin Alkaline Phosphatase (Sigma), diluted 1:10,000 with 0.5\% BSA/PBS-Tween, is then added at $100 \mu \mathrm{l} /$ well. Each plate is incubated $50 \mathrm{minutes}$ with gentle shaking, washed with PBS-Tween, and blotted dry. Lumi-Phos 530 (Lumigen, Shouthfield, MI) is then added $100 \mu \mathrm{l} /$ well, and incubated 30 minutes with gentle shaking. Light emissionfrom each plate is then measured using a microtiter plate luminometer (ML 1000; Dynatech Laboratories, Inc.). A standard curve for each plate was computed, and results for the test samples are calculated from the standard curve by extrapolation using Biocalc Data Analysis Software (BioCalc J.V., Herdon, VA).

It is now appreciated that the specificity of the antigen-antibody bond allows acurate identification and discrimination of any molecule to which an antibody can be raised. ELISA is one of immunological tests which is probably the most widely used of all immunological assays for antibodies since large numbers of tests can be performed in a relatively short time. This technique is exquisitely sensitive for detecting antigens and antibodies, and it is extremely economical in the use of reagents (Roitt et al., 1985). Hence, the ELISA technique was applied in these studies to measure levels of inflammatory markers in whole blood, serum, or NAL fluid assay.

\subsection{Aims and outline of the dissertation}

In this study, questionnaires, lung function measurements, and biological marker assays are used in combination to analyse occupational respiratory symptoms of chronic non-specific airway diseases such as occupational asthma and chronic bronchitis in workers exposed to chemicals, coal dust, and cotton dust. Peripheral (blood) or local (nasal) lood inflammatory markers are used to evaluate the respiratory health effect of occupational exposure.

Nasal lavage was applied to evaluate the effect of exposure to endotoxin in cotton dust on cytokine levels in NAL fluid. Since many of the cell types found in the upper airway (naso-pharyngeal region) are the same or similar to cells 
found in the trachea and bronchi, inflammatory markers in NAL fluid were also used to learn about inflammatory mechanisms by studying the readily accessible human nasal mucosa rather than the relatively in accessible bronchial mucosa. Moreover, as the subsequent exudation of plasma from subepithelial microvessels across mucosa into the lumen of upper airway may also contribute to the level of inflammatory markers in NAL fluid, inflammatory markers in blood were related to those in NAL fluid.

The general aim of this dissertation was to evaluate a multifunctional approach to detect chronic non-specific airway diseases with special interest in occupational asthma and chronic bronchitis. Assessment of inflammatory markers both in blood and NAL fluid was done intensively in order to use inflammatory markers as an alternative or a complementary tool to detect those diseases in occupational setting.

The specific aims of this dissertation are:

1. To evaluate the repeated, long-term use of two methods of lung function measurement, namely spirometry and the forced oscillation technique (FOT) in detecting occupational airway obstruction, and to study relationships between lung function decline and specific exposure and smoking.

2. To evaluate several peripheral blood cytokines in chemical workers and coal workers, which are related to occupational asthma (IL-4, IL-5, and IFN- $\gamma$ ) and chronic bronchitis (proinflammatory cytokines; IL-8 and TNF$\alpha$ ), that might be useful for early detection of occupational respiratory diseases in practical use. Those inflammatory markers were also related to specific occupational exposure both in chemical and coall workers.

3. To evaluate the effects of endotoxin exposure to cytokine levels in NAL and lung function changes in cotton workers; and to investigate the relation between inflammatory markers in serum and NAL.

The first goal has been approached in 136 chemical workers from 7 different production processes during a 5 year follow-up study. The outcome of impedance measurements and flow volume curves was compared, and the relationship between lung function decline and specific production process and smoking was analysed. This study is presented in Chapter 2.

The second study has been performed in two different populations of workers, namely chemical workers and coal miners. Relationship between the above cytokines and respiratory symptoms as well as lung function, chemicall exposure, and personal characteristics was studied among 106 chemical workers. Furthermore, the role of several cytokines both in serum (IL-8, soluble TNF-R55 and TNF-R75) and monocyte (IL-6, TGF- $\beta$, and TNF- $\alpha$ ) supernatants of 104 retired coal miners was analyzed and related to respiratory symptoms and lung function after correction for age, smoking and (cumulative) dust exposure. These studies are presented in Chapter 3 and 4 respectively.

The third study has been conducted in a small group of cotton workers in a textile factory. NAL was used as a method to study nasal response to endotoxin exposure in a short longitudinal study design. Proinflammatory cytokine release 
(IL-6 and IL-8), several attenuating factors i.e. soluble tumor necrosis factor receptor-75 (sTNF-R75), soluble intracellular adhesion melecule-1 (sICAM-1), and markers of cell response (uric acid, albumin) were masured and correlated to cotton dust and endotoxin exposure, as well as to short-term changes in lung function. In order to investigate the relationship between inflammatory markers in serum and NAL and interrelationship among those inflammatory markers in NAL, other inflammatory markers such as interleukins (IL-4, IL-5), interferon- $\gamma$ (IFN- $\gamma$ ), markers of venule exudation (albumin, uric acid), and response to endotoxin exposure : lipopolysaccaride (LPS) binding protein (LBP) and bactericidal/permeability-increasing protein (BPI) were also measured. The results of these studies are presented in Chapter 5 and 6.

Finally, a general discussion is presented in Chapter 7 with regard to results and feasibility of molecular epidemiology approach as an alternative or a complement to detect chronic non-specific airway diseases in occupational settings.

\section{References.}

A hman M, Holmström, Ingelman-Sundberg H (1995) Inflammatory markers in nasal lavage fluid from industrial arts teachers. Am J Ind Med 28:541-550.

American Thoracic Society (1987) Standards for the diagnosis and care of patients with chronic obstructive pulmonary disease COPD and asthma. Am Rev Respir Dis 137:225-243.

American Thoracic Society (1993) Guidelines for the evaluation of impairment/disability patients with asthma. Am Rev Respir Dis 147:1056-1061.

Axon EJ, Beach JR, Burge PS (1995) A comparison of some of the characteristics of patients with occupational and non-occupational asthma. Occup Med 45:109-111.

BAL co-operative Group Steering Committee (1990) Bronchoalveolar lavage constituents in healthy individuals, idiopathic pulmonary fubrosis, and selected comparison groups. Am Rev Respir Dis 141 (suppl.):S169-S202.

Becklake MR (1989-a) Occupational exposure: evidence for a causal relationship with chronic obstructive puimonary disease. Am Rev Respir Dis 140:85-91.

Becklake MR (1989-b) Occupational pollution. Chest 196:372-378.

Becklake MR (1994) Symptoms and pulmonary functions as measures of morbidity. Ann Occup Hyg 38:468-580.

Becklake MR (1995) Relationship of acute obstructive airway change to chronic (fixed) obstruction. Thorax 50 (Suppl. 1):S16-21.

Bernstein DI, Bernstein IL, Malo JL, Chan-Yeung M (1993) Definition and classification of asthma. In: Bernstein IL, Chan-Yeung M, Malo JL, and Bernstein DI (Eds) Asthrna in the workplace. New York, Marcel Dekker, pp.1-4.

Blaski CA, Watt JL, Quinn TJ, Thorne PS, Schwartz DA (1996) Nasal lavage cellularity, grain dust, and airflow obstruction. Chest 109:1086-1092. 
Borm PJA (1994) Biological markers and occupational lung disease: mineral dust induced respiratory disorders. Exp Lung Res 20:457-470.

Borm PJA, Schins RPF, Derhaag TJM, Kant I] (1996): Cross-shift changes in blood inflammatory markers occur in the absence of airway obstruction in workers exposed to grain dust. Chest 109:1078-1083.

Bretland PM (1994) Imaging in occupational disease of the lung. Part I: Chest radiology, In: Parkes WR (Ed) Occupational lung disorders. Oxford, Butterworth-Heinemann, pp.160182.

Broaddus VC, Hebert CA, Vitangcol RV, Hoeffel JM, Bernstein MS, Boyland AM (1992): Interleukin-8 is a major neutrophilic chemotactic factor in pleural fluid of patients with empyema. Am Rev Respir Dis 146:825-830.

Brochard L, Pelle G, De-Palmas I, Brochard P, Carre A, Lorino H, Harf A (1987) Density and frequency dependence of resistance in early airway obstruction. Am Rev Respir Dis 135:579-584.

Brooks SM, Welss MA, Bernstein IL (1985) Reactive airways dysfunction syndrome (RADS). Persistent asthma syndrome after high level irritant exposures. Chest 88:376-384.

Brooks SM and Kalica AR (1987) Strategies for elucidating the relationship between. occupational exposures and chronic airflow obstruction. Am Rev Respir Dis 13:268-273.

Chan-Yeung $M$, Lam $S$, Koener $S$ (1982) Clinical features and natural history of occupationall asthma due to western red cedar (thuja plicata). Am J Med 72:411-415.

Chan-Yeung M and Lam S (1986) Occupational asthma - state of the art. Am Rev Respir Dis 133:686-703.

Christiani DC (1994) Chronic obstructive pulmonary disease (COPD), alpha-1 antiprotease deficiency and occupational exposures. In: Proc ATS postgraduate course 7, May 21, 1994., occupational and environmental respiratory disorders: exposure, mechanisms, management and prevention. Boston, Massachusetts.

Ciba (1959) Terminology, definition, and classification of chronic pulmonary emphysema and related conditions: a report of conclussions of a Ciba Guest Symposium. Thorax 14:286-299.

Colditz I and Morley J (1991) Mediators of inflammatory cell accumulation in the lung. In: Bray M.A. and Anderson W.F. (Eds) Mediators of Pulmonary inflammation, New York. Dekker, pp.513-532.

Cole P J and Wilson $\mathrm{R}$ (1989) Host-microbial interrelationship in respiratory infection. Chest $95: 217-221$.

Corrigan CJ and Kay AB (1992) T cells and eosinophils in the pathogenesis of asthma. Immunol Today 13:501-507.

Cullen MR, Cherniak MG, Rosenstock L (1990a) Medical Progress. Occupational Medicine. N Engl J Med 9:594-601.

Cullen MR, Chernialk MG, Rosenstock L (1990b) Medical Progress. Occupational Medicine. N Engl I Med 10:675-683. 
Cullinan P (1991) Aetiological factors in chronic sputum production. Thorax 46:773.

Dearman RJ and Kimber I (1992) Divergent immune response to respiratory and contact chernical allergens: antibody elicited by phthalic anhydride and oxazolone. Clin Exp Allergy 22:241-250.

Del-Prete G, Maggi E, Romagnani S (1994) Biology of disease, human Th1 and Th2 cells: functional properties, mechanism of regulation, and role in disease. Lab Invest 70:299-306.

Desch CE, Kovachi NL, Present W, Broyles C, Harlan JM (1989) Production of human tumor necrosis factor from whole blood ex-vioo. Lymphokine Res 8:141-146.

Devlin RB, McKinnon KP, Noah T, Becker S, Koren HS (1994) Ozone induce release of cytokines and fibronectin by alveolar macrophages and airway epithelial cells. Am J Physiol 266:612-619.

Diaz-Sanchez D, Tsien A, Casillas A, Dotson AR, Saxon A (1996) Enhanced nasal cytokine production in human beings after in vivo challenge with diesel exhaust particles. J Allergy Clin Immunol 98:114-123.

Djeu JY, Matsushima K, Oppenheim JI, Shiotsuki K, Blanchard DK (1990) Function activation of human neutrophils by recombinant monocyte-derived neutrophil chemotactic factor/IL-8. I Immunol 144:2205-2210.

Donnelly SC, Strieter RM, Kunkel SL, Walz A, Robertson CR, Carter DC, Grant IS, Pollok AJ, Haslett C (1993) Interleukin-8 and the development of adult respiratory distress syndrome in at risk patient group. Lancet 341:643-647.

Dubois $\mathrm{AB}, \mathrm{Brody} \mathrm{AW}$, Lewis $\mathrm{DH}$, Burgees $\mathrm{BF}$ (1956) Oscillation mechanistics of lungs and chest in man. J Appl Physiol 8:587-594.

Eller J, Lapa-E-Silva JR, Poulter LW, Lode H, Cole PJ (1994) Cells and Cytokines in chronic bronchial infection. In Chignard M, Pretolani M, Renesto P, Vargaftig BB (Eds) Cells and cytokines in lung inflammation. New York, The New York Academy of Sciences, pp.331345 .

Enarson D, Vedal S, Chan-Yeung M (1985) Rapid decline in FEV 1 in grain handlers. Am Rev Respir Dis 132:814-817.

Erjefalt I and Persson CGA (1989) Inflammatory passage of plasma macromolecules into airway wall and lumen. Pulm Pharmacol 2:93-102.

Fisher ThM, Kuehr J, Pullwitt A, Meinert R, Foster J, Studnicka M, Koren H (1993) Ambient ozone causes upper airways inflammation in children. Am Rev Respir Dis 148:961-964.

Fletcher CM and Peto R (1977) The natural history of chronic airflow obstruction. Br Med J 1:1645-1648.

Graham DE and Koren HS (1990) Biomarkers of inflammation in ozone-exposed humans: comparison of of the nasal and bronchoalveolar lavage. Am Rev Respir Dis 142:152-156.

Greenburg SD, Boushy SF, Jenkins DE (1987) Chronic bronchitis and emphysema: correlation of pathologic findings. Am Rev Respir Dis 96:918-928. 
Greiff L. Pipkorn U, Alkner U, Perssion CGA (1990) The nasal pool-device applies controlled concentration of solutes on human nasal airway mucosa and samples its surface exudation/secretions. Clin Exp Allergy 20:253-259.

Hack CE, Hart M, Van-Schijndel RI, Eerenberg AJ, Nuijens IH, Thijs LG, Aarden LA (1992): Interleukin-8 in sepsis: Relation to shock and inflammatory mediator. Infect Immunol $60: 2835-2842$.

Haslam PL (1994) Basic immunology and immunopathology. In: Parkes WR (Ed): Occupational lung disorders. Oxford, Butterworth-Heinemann Ltd, 82-87.

Higgins MW (1989) Chronic airways disease in the United States: trends and determinants. Chest 196:328-334.

Hoidal IR (1994) Pathogenesis of chronic bronchitis. Semin Respir Infect 9:8-12.

Holtzman MJ, Sampath D, Castro $\mathrm{M}_{r}$ Look DC, Jayaraman S (1996) Perspective, The Onetwo of $T$ helper cells: does interferon- $\gamma$ knock out the Th2 hypothesis for asthma ? Am I Respir Cell Mol Biol 14:316-318.

Hudson P, Cartier A, Pineau L (1985) Follow-up of occupational asthma caused by crab and various agents. J Allergy Clin Immunol 76:682-687.

Hunninghake GW, Gadek JE, Kawanami O, Ferrans VJ, Crystal RG (1979) Inflammatory and immune processes in the human lung in health and disease: evaluation by bronchoalveolar lavage. Am J Pathol 97:149-198.

Husband JE and Fry IK (1981) Chapter 5. In: Computed tomography of the body. London, Macmillan, pp.40-54.

International Labour Office (1980) Guidelines for the use of ILO international classification of radiographs of pneumoconiosis. Occupational Safety and Health Series No.22, Geneva, ILO.

Jorna THJM (1994) Analysis of respiratory impairment due to occupational exposure, Maastricht, Universitaire Pers Maastricht, pp.96-108.

Karol MH (1992) Occupational asthma and allergic reactions to inhaled compounds. In:

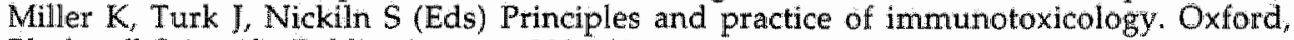
Blackwell Scientific Publications, pp.228-241.

Keatings VM, Collins PD, Scott DM, Bames PJ (1996) Differences in interleukin-8 and tumor necrosis factor- $\alpha$ in induced sputum from patients with chronic obstuctive pulmonary disease or asthma. Am J Respir Crit Care Med 153:530-534.

Kelley J (1990) Cytokines of the lung. Am Rev Respir Dis. 141:765-788.

Kelly FJ, Mudway IS, Blomberg A, Sandström T (1996) Use of repeated nasal lavage to access antioxidant status of the upper respiratory tract in non-smoking subjects. Eur Respir $\int 9($ suppl 23$): 415$ s.

Khoury MI, Adams MI, Flanders WD (1988) An epidemiologic approach to ecogenetics. Am J Hum Genet $42: 89-95$. 
Kimber I and Dearman RJ (1992) The mechanisms and evaluation of chemically-induced allergy. Toxicol Lett 64/65:79-84.

Klech $\mathrm{H}$ and Pohl W (Eds) (1989) Techrical recommendations and guidelines for bronchoalveolar lavage (BAL): report of The European Society of Pneumology Task Group on BAL. Eur Respir ] 2:561-585.

Koren HS, Devlin RB, Graham DE, Mann R, MoGee MP, Horstman DH, Kozumbo WJ, Becker S, House DE, McDonell WF, Bromberg PA (1989) Ozone-induced inflammation in the lower airways of human subjects. Am Rev Respir Dis 139:407-415.

Kremer AM, Pal TM, Schouten JP, Rijcken B (1995) Airway hyperresponsiveness in workers exposed to low levels of irritants. Eur Respir J 8:53-61.

Làndser FI, Nagels J, Demedts M, Billiet L, Van de Woestijne KP (1976) A new method to determine frequency characteristics of the respiratory system. J Appl Physiol 41:101-106.

Laturell CB and Ericksson S (1963) The elctrophoretic $\alpha 1$-globulin pattern of serum in $\alpha 1$ antitrypsin deficiency. Scand J Clin Lab Invest 15:132-140.

Leeuwenberg JFM, Dentener MA, Buurman WA (1994): Lipopolysaccharide LPS-mediated soluble TNF receptor release and TNF receptor expression by monocytes: rolle of CD14, LPS binding protein, and bactericidal permeability increasing protein. J Immunol 152:5070-5076.

Liddell FDK and Morgan WKC (1978) Methods of assessing serial films of the pneumoconiosis: a review. J Soc Occup Med 28:6-15.

Lynch $\mathbb{P}$, Standiford TJ, Rolfe MW, Kunkel SL, Strieter RM (1992): Neutrophilic alveolitis in idiopathic pulmonary fibrosis. Am Rev respir Dis 145:1433-1439.

Malo JL, Ghezzo H, D'Aquino C, L'Archeveque J, Chan-Yeung M (1994) Natural history of occupational asthma: relevance of type of agent and other factors in the rate of development of symptoms in affected subjects. J Allergy Clin Immunol 94:102-109.

Medical Research Council (1976) Questionmaire on respiratory symptoms. London. Medical Research Conuncil.

Meredith SK and McDonald JC (1994) Work-related respiratory disease in the United Kingdom 1989-1992: a report on the SWORD project. Occup Med 44:183-189.

Mitchell RS, Ryan SF, Petty TL, Filley GF (1966) The significance of morphologic chronic hyperplastic bronchitis. Am Rev Respir Dis 93:720-729.

Morgan WKC (1986) On dust, disability and death. Am Rev Respir Dis 134:639-641.

Mosmann TR, Schunmacher JH, Street NF, Budd R, O'Garra A, Fong TA, Bond MW, Moore KW, Sher A, Fiorentino DF (1991) Diversity of cytokine synthesis and function of mouse CD4+ $\mathrm{T}$ cells. Immunol Rev 123:209-229.

National Research Council (1987) Biological markers in environmental health research. Environ Health Perspect $77: 3-9$.

Nerad JL, Griffiths JK, Van der Meer JW, Endres S, Poutsiaka DD, Keusch GT, Bennish M, Salam MA, Dinarello CA, Cannon JG (1991) Interleukin-1 (IL-1), IL-1 receptor antagonist and TNF- $\alpha$ production in whole blood. J Leukoc Biol 52:687-692. 
Newman Taylor AJ (1994) Occupational asthma. In: Parkes WR (Ed). Occupational lung disorders, Oxford, Butterworth-Heinemann, pp.710-729.

Noah IL, Henderson FW, Henry MM, Pederi DB, Devlin DB (1995-a) Nasal lavage cytokines in normal, allergic, and asthmatic school-age children. Am J Resp Crit care Med 152:1290-1296.

Noah TL, Henderson FW, Wortman IA, Devlin RB, Handy J, Koren HS, Becker S (1995-b) Nasal cytokine production in viral acute upper respiratory infection of childhood. I Infect Dis 171:584-592.

Orehek J, Nicoli MM, Delpierre S, Beaupre A (1981) Influence of the previous deep inspiration on the spirometric measurement of provoked broncho-constriction in asthma. Am Rev Respir Dis 123:269-72.

Oxman AD, Muir DCF, Shannon HS, Stock SR, Hznido E, Lange H] (1993) Occupational dust exposure and chronic obstructive pulmonary disease: a systemic overview of the evidence. Am Rev Respir Dis 148:38-48.

Parkes WR (1994) Chronic bronchitis, airflow obstruction and emphysema. In Parkes WR (Ed) Occupational lung disorders. Oxford, Butterworth-Heinemann, Pp.222-237.

Pazdrak K, Górski P, Krakowiak A, Ruta U (1993) Changes in nasal lavage fluid due to formaldehyde inhalation. Int Arch Oocup Environ Health 64:515-519.

Perera F (1987) Molecular epidemiology: a novel approach to the investigation of pollutant-

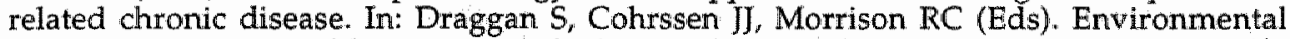
impacts on human health: the agenda for long-term research and development. New York, Praeger, pp.51-88.

Persson CGA, Svensson C, Greiff L, Andersson M, Wollmer P, Alkner U, Erjefalt I (1992) Editorials. The use of the nose to study the inflammatory response of the respiratory tract. Thorax 47:993-1000.

Postma DS, Bleecker ER, Amelung PJ, Holroyd KI, Xu-J, Panhuysen CI, Meyers DA, Levitt RC (1995) Genetic susceptibility to asthma - bronchial hyperresponsiveness coinherited with a major gene for atopy. $\mathrm{N}$ Engl J Med 333:894-900.

Quanjer PhH (1983) Standardized lung function testing. Bull Eur Physio-path Respir 19 (Suppl. 5):1-95:

Ras G, Wilson R. Todd $G$, Taylor G, Cole PJ (1990) Effect of bacterial products on neutrophil in vitro. Thorax 45:276-280.

Reid L (1960) Measurement of bronchial mucous gland layer: a diagnostic yardstick in chronic bronchitis. Thorax 15:132-141.

Reid L (1967) The pathology of emphysema. London, Lloyd Luke.

Reynolds HY and Newball HH (1974) Analysis of proteins and respiratory cells obtained from human lung by bronchial lavage. J Lab Clin Med 84:559-573.

Richman-Eisenstat JB, Jorens PG, Hebert CA, Ueki I, Nadel JA (1993) Interleukin-8: an important chemotractant in sputum of patients with chronic inflammatory airway diseases.

Am J Physiol 246:L413-418. 
Riise GC, Ahlstedt S, Larsson S, Enader 1, Jones 1, Larsson P, Andersson B (1995) Bronchial inflammation in chronic bronchitis assessed by measurement of cell products in bronchial lavage fluid. Thorax 50:360-365.

Roitt I, Brostoff J, Male D (1985) Immunology. London, Gower Medical Publishing, pp.2535.

Romagnani S (1995) Biology of human Th1 and Th2 cells. I Clin Immunol 15:121-129.

Romagnani S (1992) Induction of Th1 and Th2 responses: a key role for the "natural' immune response? Immunol Today 13:379-381.

Rom WN, Bitterman PB, Rennard SI, Cantin A, Crystal RG (1987) Characterization of the lower respiratory tract inflammation of non-smoking individuals with interstitial lung: disease associated with chronic inhalation of inorganic dust. Am Rev Respir Dis 136:14291434.

Ross DJ, Sallie BA, MCDonald JC (1995) SWORD "94: survellance of work-related and occupational respiratory disease in the UK. Occup Med 45:175-178.

Sagel SS and Aronberg DJ (1982) Chapter 4, in Lee KJ, Sagel SS, and Stanley KJT (Eds) Computed body tomography, New York, Raven, pp.55-98.

Schins RPF, Van Hartingsveldt B, Borm PJA (1996) Ex vivo cytokine release from whole blood: a routine method for health effect screening. Exp Toxicol Pathol 48:494-496.

Schuimaar RP, Benenati SV, Friedman B, Buchner BS (1991) Do cytokines play a role in leukocyte recruitment and activation in the lung? Am Rev Respir Dis 143:1169-1174.

Schulte PA (1989) A conceptual framework for the validation and use of biological markers. Environ Res 4:129-144.

Schulte PA (1993) A conceptual and Historical framework for molecular epidemiology. In: Schulte PA and Perera FP (Eds) Molecular epidemiology, principles and practices. San Diego, Academic Press, pp.3-44.

Sluiter H], Koeter GH, de-Monchy JG, Postma DS, de-Vries K, Orie NG (1991) The Dutch hypothesis (chronic non-specific lung disease) revisited. Eur Respir J 4:479-489.

Snider GL, Kleinerman J, Thurlbeck WM, Bengali ZH (1985) The definition of emphysema: report of National Heart, Lung and Blood Institute Division of Lung Diseases Workshop. Am Rev Respir Dis 132:182-185.

Speizer FE and Tager IB (1979) Epidemiology of chronic mucus hypersecretion and obstructive airways disease. Epidemiol Rev 1:124-142.

Steerenberg PA, Fischer PH, Meyling FG, Willighagen J, Geerse E, Vd Vliet H, Ameling C, Boink ABTJ, Dormans J, Van Bree L, Loveren HV (1996) Nasal lavage as a tool for health effect of photochemical air pollution. Hum Exp Toxicol 15:111-119.

Stoller JK and Aboussouan LS (1995) Chronic obstructive lung diseases: emphysema, chronic bronchitis, bronchiectasis, and cystic fibrosis. In: George RB, Light RW, Matthay MA, Matthay RA (Eds), Chest medicine, essentials of pulmonary and critical care medicine. Baltimore, Williams \& Wilkins, pp.201-246. 
Strieter RM, Remick DG, Ham JM, Colletti LM, Lynch JP, Kunkel SL (1990) Tumor necrosis factor-alpha gene expression in human whole blood. I Leukoc Biol 47:366-370.

Strieter RM, Standiford TJ, Rolfe MW, Kunkel SL (1993) Interleukin-8. In: Kelley ) (Ed) Cytokines of the lung. New York, Marcel Delkker, pp.294.

Swain SL (1995): CD4 T-cell development and cytokine polarization: an overview. J Leukoc Biol 57:795-798.

Taylor $R G$, Joyce $H$, Gross $E$, Holland $F$ and Pride NB (1985) Bronchial reactivity to inhale histamine and annual rate decline in $\mathrm{FEV}_{1}$ in male smokers and ex-smokers. Thorax 40:9-16.

Thurlbeck WM (1976) Chronic airflow obstruction in lung disease. Philadelphia, WB Saunders, pp.31-95.

Thurlbeck WM, Henderson JA, Fraser R, Bates DV (1970) Chronic obstructive lung disease: a comparison between clinical, roentgenologic, functional and morphologic criteria in chronic bronchitis, emphysema, asthma, and bronchiectasis. Medicine 49:81-145.

Tollerud DJ, Sparrow D, Weiss S, Guevarra L (1994) Chemiluminescence assay for human cytokines. J Cell Bioch 18 (Suppl.):A26.

Tornding $G$, Alexandersson $R$, Hendenstierna $G$, Plato $N(1990)$ Decreased lung function and exposure to diisocyanates (HDI and HDI-BT) in car repair painters: observations on reexamination 6 years after initial study. Am J Ind Med 17:299-310.

Traver GA, Cline MG, Burrows B (1979) Predictors of mortality and in chronic obstructive pulmonary disease. A 15-year follow-up study. Am Rev Respir Dis 119:895-902.

Van Noord JA, Clément I, Cauberghs M, Mertens I, Van de Woestijne KP, Dennedts M (1989) Total respiratory resistance and reactance in patients with diffuse interstitial lung disease. Eur Respir I 2:846-852.

Venables KM, Burge PS, Davison. AG. Newman Taylor AJ (1984) Peak flow rate records in surveys: reproducibility of observers' report. Thorax 39:828-832.

Wallaert B, Lassalle Ph, Fortin F, Aerts C, Bart F, Fournier E, Voisin C (1990) Superoxide anion generation by alveolar inflammatory cells in simple pneumoconiosis and progressive massive fibrosis of non smoking coal workers. Am Rev Respir Dis 141:129-133.

Walters EH and Gardiner PV (1991) Bronchoalveolar lavage as a research tool. Thorax 46:613-618.

Wang Z, Larsson $K$, Palmberg L, Malmberg P, Larsson $\mathbb{P}$, Larsson L (1997) Inhalation of swine dust induces cytokine release in the upper and lower airways. Eur Respir J 10:381387.

Wardlaw A] (1993) The role of air pollution in asthma. Clin Exp Allergy 23:81-96.

Watanuki Y, Suzuki S, Nishikawa M, Miyashita A, Okubo T (1994) Correlation of quantitative CT with selective alveolobronchogram and pulmonary function tests in emphysema. Chest 106:806-813. 
Woolcock A] (1992) Epidemiology of asthma. Am Rev Respir Dis 146:1458-1359.

Wouters EFM (1990) Total respiratory impedance measurement by forced oscillation: a non invasive method to assess bronchial response in occupational medicine. Exp Lung Res $16: 25-40$. 


\title{
Chapter 2
}

\section{A FIVE-YEAR FOLLOW-UP OF LUNG FUNCTION AMONG CHEMICAL WORKERS USING FLOW VOLUME AND IMPEDANCE MEASUREMENTS}

\author{
Soedjajadi Keman ${ }^{1}$, Brigitte Willemse ${ }^{1}$, Geert Jan Wesseing ${ }^{2}$, Eduard Kusters ${ }^{3}$, \\ and Paul J.A. Borm1.
}

${ }^{1}$ Dept. of Health Risk Analysis and Toxicology, ${ }^{2}$ Dept. of Pulmonology, Maastricht University, Maastricht, The Netherlands and ${ }^{3}$ Free University of Brussels, Brussels, Belgium

\begin{abstract}
Impedance of the respiratory system, measured using the forced-oscillation technique (FOT) has repeatedly been proposed as a tool for occupational health screening. The aim of this study was to compare the outcome of impedance measurements and flow-volume curves and to study relationships between lung function decline and specific exposures and smoking. Both methods were applied in 136 chemical workers during a five-year follow-up (1990-1995).

The prevalence of airway obstruction ( $F E V_{1}<80 \%$ predicted) at both time-points was about $5 \%$ but did not necessarily include the same subjects. The average decline in FEV over five years was $200 \mathrm{~mL}$ (predicted decline: $160 \mathrm{~mL}$ ). Although most impedance parameters correlated to flow volume parameters in both years, a rapid 5-year decline of $\mathrm{FEV}_{1}(>330 \mathrm{~mL}$ ) was only accompanied by a significant decrease in the reactance at $8 \mathrm{~Hz}$ $(\mathrm{X} 8)$ and an increase in the resonance frequency $\left(f_{0}\right)$. Interestingly, decline in FEV 1 was significantly dependent on age, years of employment, packyears, $\mathrm{FEV}_{1}$, and all impedance parameters at a start in $1990\left(r^{2}=0.13, p=0.01\right)$. Similarly, the increase in $f_{0}$ was significantly dependent on age, years of employment, packyears, $f_{0 r}$ FEV $_{1}, F V C$, PEF and MMEF at a start $\left(r^{2}=0.32, p<0.01\right)$. Rapid decliners in $\mathrm{FEV}_{1}$ were relatively more present in acids [Relative risk $(R R)=2.14$, maintenance workers $(R R=2.1)$ and bulk/transport $(\mathrm{RR}=1.78)$, but none of these ratios' was significant. Lung function, however, was significantly lower in the bulk/transport workers ( $n=14)$ compared to the rest, based both on flow volume (FVC, FEV 1 ) and impedance $\left(X 8, f_{0}\right)$ measurements. Smoking had a significant effect on most flow volume parameters but only for frequency dependence among the impedance outcomes.

It is concluded that alterations in impedance parameters do reflect changes in flow volume curves induced by age, smoking and occupational exposure. Therefore, these data are a valuable extension to current cross-sectional data.
\end{abstract}

Published in :

European Respiratory Journal 1996; 9:2109-2115. 


\section{Introduction}

Although a decline in FEV $_{1}$ is generally considered as a golden standard to detect airflow limitation, different (mechanical) alterations of the respiratory system can influence this parameter. Impedance measurements of the respiratory system by the forced oscillation technique can provide additional information on the mechanical characteristics of the respiratory system (Làndser et al., 1976; Jorna et al., 1994-a). Firstly, it was demonstrated that impedance measurements are sensitive in detecting airflow limitation induced by specific or nonspecific challenge tests (Jorna et al., 1993; Pairon et al., 1994) and in patients with asthma (Wouters et al., 1989) and COPD (Ying et al., 1990). Secondly, in the past decadle several cross-sectionall investigations (Jorna et al., 1994-a; Brochard et al., 1987; Pham et al., 1995) have shown that impedance measurements also offer a simple non-invasive method to detect airflow limitation in different occupational settings. Some of these studies showed that the forced oscillation technique provided better sensitivity to distinguish subjects with respect to exposure of irritant gases (Brochard et al., 1987), organic dust and endotoxin (Jorna et al., 1994b) or to detect mild obstructive patterns in underground coal workers without apparent X-ray abnormalities (Pham et a1., 1995). However, the pattern of impedance measurements and in particular its' comparisons with flow volume parameters are highly dependent both on type and extent of exposure (Jorna et al., 1994-a). Although we and others have proposed the forced oscillation techrique as a tool for epidemiology of occupational lung diseases (Wouters, 1990; Jorna et al., 1994-a; Pham et al., 1995), few longitudinal data on impedance measurements are available. Therefore we performed a follow up study of lung

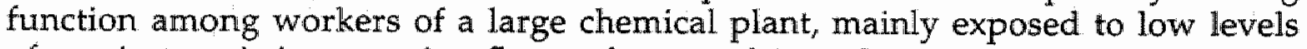
of respiratory irritants, using flow volume and impedance measurements.

The objectives of this study were (i) to relate alterations in impedance parameters to changes in flow volume parameters in workers exposed to chemicals and (ii) to study whether lung function (decline) was related to specific exposure categories.

\section{Methods}

\section{Study design and protacol}

This study was designed as a 5-year (1990-1995) follow up study. Male workers from a large chemical plant who came to the occupational physician for a routine yearly medical checkup in April and May 1990 were included in the study after written informed consent $(N=160)$. All subjects had to complete three impedance measurements and three flow volume curves. Impedance measurements were always performed before flow volume curves to avoid the influence of forced inspiratory maneuvers on the bronchial tonus (Oherek et al. 1981). In the beginning of 1995 all subjects were asked to participate in this study, and then in the months of April and May 1995 the same procedure was performed after evaluation of a self administered Dutch version of the British 
Medical Research Council (BMRC) standardized questionnaire on respiratory symptoms, smoking habits, and additional questions concerning working history in the second phase of study. 24 of 160 workers did not participate in this study for various reasons ( 3 no longer employed, 17 not satisfied with first study in 1990, 4 ill at time of study). Finally 136 complete data-sets were obtained and analyzed. Monitoring data were available for each production process but these were not used because of the complexity of multiple exposure and the limited number of subjects. Seven main production processes/personel groups were distinguished: chemicals, acids, polymers, polyurethanes, bulk/transport and maintenance personnel, and others (see also table 4). Bulk/transport workers are mainly exposed to nitrogen, phosphor and potassium (NPP)-containing dust during loading and scraping.

\section{Lung function measurements}

Forced expiratory flow volume curves were recorded according to European Community of Coal and Steel (ECCS) criteria using a Vicatest P1 dry spirometer (Mijnhardt, Bunnik, The Netherlands). Three recordings within 5\% of forced vital capacity or a $100-\mathrm{ml}$ range were obtained from each subject. Parameters derived from the flow volume curves were: forced vital capacity (FVC), forced expiratory volume in one second $\left(\mathrm{FEV}_{1}\right), \mathrm{FEV}_{1} / \mathrm{FVC}$ ratio, peak expiratory flow volume (PEF), maximal mid expiratory flow volume (MMEF), $\mathrm{MEF}_{50}$ and $\mathrm{MEF}_{25}$, being the flow after $75 \%$ exhalation. The first four parameters are the effort-dependent part and the last three are the effort-independent part of the flow volume curve. The $\mathrm{FVC}_{2} \mathrm{FEV}_{1}$, and $\mathrm{FEV}_{1} / \mathrm{FVC}$ ratio are used to describe the airway obstruction in the large airways whereas MMEF values are used to describe airway obstruction in the small airways. All flow volume values were related to the reference values of the European Community of Coal and Steel (ECCS )for individual diagnosis (Quanjer, 1983). A deflection of value of two or more standard deviations (i.e., a value less than $80 \%$ of the standard value) of $\mathrm{FEV}_{1}$ reflected airway obstruction. The spirometer was calibrated two times daily and all subjects were measured on the same spirometer by the same investigator on both occasions.

Impedance of the respiratory system was measured using the technique originally described by Làndsér et al (1976). The seated subject, wearing a noseclip, supports the cheeks with his hands and breathes quietly via a tube. A pseudorandom noise pressure signal containing all harmonics of $2 \mathrm{~Hz}$ from 4 to $48 \mathrm{~Hz}$ is applied at the mouth by means of a loudspeaker. Recorded pressure and flow signals were analyzed by spectral analysis techniques. Mean values of three successive measurements, each lasting 8 seconds were used in the analysis. Of the obtained impedance data, the resistance at $8 \mathrm{~Hz}(\mathrm{R} 8)$, at $28 \mathrm{~Hz}(\mathrm{R} 28)$, the difference between R28 and R8 (frequency dependence (FD) of resistance, signifying the course of the resistance versus frequency curve), the reactance at $8 \mathrm{~Hz}(\times 8)$ and the resonant frequency ( $f_{0}$, the frequency at which $X$ equals zero) were used for analysis. $R 8$ was chosen because at this frequency usually coherence function $>0.95$ were obtained, which was not always obtained at lower frequencies. A negative $F D$ and a resonance frequency $\left(f_{0}\right)$ exceeding $15 \mathrm{~Hz}$ were regarded as indicative for airway obstruction. The equipment was calibrated dailies and all measurements were performed using the same apparatus during both study 
episodes. Short term variability of impedance of the respiratory system was tested among 10 healthy subjects for 3 weeks, 3 days/week, and showed variation coefficients $10.5 \%, 14.6 \%, 137 \%$, and $14.2 \%$ for $\mathbb{R} 8, X 8, F D$, and $\mathrm{f}_{0}$ respectively. Long term wariability was derived from a follow-up study 10 among grain workers (Borm et al., 1996), showing similar values for the above parameters at 2-year follow-up.

\section{Statistical analysis}

Packyears were calculated from the questionnaires, as average weekly of total number of packs of cigarettes smoked multiplied by the number of years smoked. Average lung function data for the same groups in 1990 and 1995 were tested for significance using the Student's t-test for paired samples (Table 2.1). Correlations of flow volume curves with impedance parameters were calculated by Pearson's correlation test (Table 2.2). Relationships between changes in FEV 1 in the quartile's groups and alterations in impedance parameters were tested by one-way ANOVA (Table 2.3). Characteristics and lung function outcomes of workers from different plants in 1995 and 1990 were tested by one-way ANOVA (Table 2.4). Relative risks (RRs) were calculated using cases were defined as subjects including in upper quartile or the group of rapid decline in $\mathrm{FEV}_{1}$ and controls as the remainder of the population studied (Table 2.4). The influences of smoking habits on lung function parameters were tested by one-way ANOVA (Table 2.5). Probability values $<0.05$ were considered as statistically significant, unless stated otherwise. All procedures were done using SPSS for Windows 6.0 software.

\section{Results}

\section{General data}

At follow-up, most flow volume parameters showed a significant decrease compared to the starting point ( $t$-test for paired samples, $p=0.01$ ). A strong correlation between both time-points was observed for most flow volume parameters (Table 2.1). Average values of flow volume parameters were not different from normal (reference) values in both years, and average decline of FVC was $90 \mathrm{~mL}, 200 \mathrm{~mL}$ for $\mathrm{FEV}_{1}, 2.5 \%$ for $\mathrm{FEV}_{1} / \mathrm{FVC}$ ratio and $0.56 \mathrm{~L} / \mathrm{s}$ for MMEF over 5 years. The decline in $\mathrm{FEV}_{1}$ of $40 \mathrm{~mL} /$ year did not differ much from the predicted decline of $32 \mathrm{~mL} /$ year from the ECCS equations (Quanjer, 1983). The estimated decline was predicted on a 5-year increase of age with height and weight remaining the same. Impedance parameters showed similar outcomes as those of the flow volume curves. Average values of impedance parameters could also be considered as normal values in both years. Most flow volume parameters were significantly decreased between 1990 and 1995, while only frequency dependence (FD) reached significance among among impedance values. Although not significant, the increase in $R 8(0.37 \mathrm{hPa} . \mathrm{s} / \mathrm{L})$ and $\mathrm{f}_{0}(0.32 \mathrm{~Hz})$ are in line with the above data. Correlation coefficients of individual measurements with those at a start were much lower than parameters derived from flow volume curves (Table 2.1). 
Airflow limitation (defined as an $\mathrm{FEV}_{1}<80 \%$ ) was present in $7(5.1 \%)$ of the subjects in 1990 and in $6(4.4 \%)$ of the subjects in 1995. Three of these subjects were included in both groups. According to impedance criteria (a negative FD and $\mathrm{f}_{0}$ exceeding $15 \mathrm{~Hz}$ ), airflow limitation was present in $5(3.8 \%)$ and $6(4.4 \%)$ of the subjects in 1990 and 1995, respectively. However, only one subject was found obstructive at both time points.

Table 2.1. Flow volume and impedance parameters in the same group of chemical workers $(\mathbb{N}=136)$ in 1990 and 1995

\begin{tabular}{|c|c|c|c|c|}
\hline Parameter & Unit & 1990 & 1995 & Corr Coeff \\
\hline $\begin{array}{l}\text { General } \\
\text { Age } \\
\text { Height } \\
\text { Weight } \\
\text { Smokers } \\
\text { - curnent } \\
\text { - past } \\
\text { - never } \\
\text { Smoking } \\
\text { - current } \\
\text { - past }\end{array}$ & $\begin{array}{c}\text { Year } \\
\mathrm{Cm} \\
\mathrm{Kg} \\
\mathrm{N} \\
\mathrm{N} \\
\mathrm{N} \\
\text { Pack-years } \\
\text { Pack-years }\end{array}$ & $\begin{array}{c}36 \\
177.11 \pm 6.58 \\
78.29 \pm 9.59 \\
39 \\
48 \\
49 \\
\\
\text { ND } \\
\text { ND }\end{array}$ & $\begin{array}{c}41 \\
77.38 \pm 6.52 \\
79.96 \pm 10.18 \\
36 \\
51 \\
49 \\
\\
16.78 \\
9.18\end{array}$ & \\
\hline $\begin{array}{l}\text { Flow Volume } \\
\text { FVC } \\
\text { FVC } \% \% \\
\text { FEV }_{1} \\
\text { FEV }_{1} \% \\
\text { FEV }_{1} / \text { FVC } \\
\text { PEF } \\
\text { PEF \% } \\
\text { MMEF } \\
\text { MMEF } \%\end{array}$ & $\begin{array}{c}\mathrm{L} \\
\% \\
\mathrm{~L} \\
\% \\
\% \\
\mathrm{~L} / \mathrm{sec} \\
\% \\
\mathrm{~L} / \mathrm{sec} \\
\%\end{array}$ & $\begin{aligned} & 5.25 \pm 0.70 \\
& 106.99 \pm 10.37 \\
& 4.02 \pm 0.60 \\
& 98.19 \pm 10.5 \\
& 76.58 \pm 6.39 \\
& 8.85 \pm 1.64 \\
& 93.16 \pm 16.2 \\
& 3.73 \pm 1.03 \\
& 81.05 \pm 20.79\end{aligned}$ & $\begin{array}{c}5.16 \pm 0.73^{* *} \\
109.58 \pm 31.06 \\
3.82 \pm 0.62^{* *} \\
96.51 \pm 10.95^{* *} \\
74.09 \pm 6.08^{* *} \\
8.65 \pm 1.46 \\
93.13 \pm 15.21 \\
3.17 \pm 0.97 * * \\
71.53 \pm 19.53\end{array}$ & $\begin{array}{l}0.91 \\
0.30 \\
0.94 \\
0.86 \\
0.76 \\
0.61 \\
0.56 \\
0.84 \\
0.80\end{array}$ \\
\hline $\begin{array}{l}\text { Impedance } \\
\text { R8 } \\
\text { X8 } \\
\text { FD } \\
\mathrm{f}_{0}\end{array}$ & $\begin{array}{c}h P a_{s} s / \mathbb{L} \\
h P a_{s} s / L \\
h P a_{s} s / L \\
H z\end{array}$ & $\begin{array}{l}2.30 \pm 0.74 \\
0.15 \pm 0.25 \\
0.53 \pm 0.48 \\
7.64 \pm 2.81\end{array}$ & $\begin{array}{l}2.67 \pm 2.51 \\
0.16 \pm 0.30 \\
0.27 \pm 0.63 \\
7.96 \pm 2.99\end{array}$ & $\begin{array}{l}0.23 \\
0.53 \\
0.32 \\
0.45\end{array}$ \\
\hline
\end{tabular}

Values are presented as mean \pm SD. Abbreviations: FVC: forced vital capacity: \% pred: percentage of predicted value; $F E V_{1}$ : forced expiratory volume in one second; PEF: peak expiratory flow; $R-B$ : resistance at $8 \mathrm{~Hz} ; \mathrm{X}-8$ : reactance at $8 \mathrm{~Hz} ; \mathrm{FD}$, frequency dependence $(\mathrm{R} 28-\mathrm{R} 8) ; f_{0}$. resonance frequency (frequency where reactance is equal to zero), ND: not determined.

\# Correlation coefficients between individual values 1990 and 1995. Significances were tested by t- test for paired samples. ${ }^{* *}=p<0.01,1990$ ws. 1995. 
No airway obstruction was detected by forced oscillation technique among 7 workers dominated obstructive by flow volume criteria in 1990, while only 1 was present among 6 obstructive workers measured by flow volume in 1995 . To compare impedance and flow volume measurements we further calculated correlation coefficients (Table 2.2). Although low, these coefficients showed quite similar values and patterns at both occasions. All impedance parameters were significantly correlated to $\mathrm{FEV}_{1}$ and to most other flow volume parameters, such as FVC and MMEF. Changes in most impedance parameters were not related to longitudinal changes in flow volume parameters. Only the alteration in reactance at $8 \mathrm{~Hz}$ was significantly $(\mathrm{p}<0.05)$ correlated to longitudinal changes in FVC and $\mathrm{FEV}_{1}$, while resonance frequency $\left(\mathrm{f}_{0}\right)$ increased significantly with the decline in $\mathrm{FEV}_{1}(\mathrm{r}=-0.22 ; \mathrm{p}<0.01)$.

Table 2.2. Correlation coefficients of flow volume and impedance parameter measurements in 136 Chemical Workers in 1990 and 1995

\begin{tabular}{|c|c|c|c|c|}
\hline Parameter & $\begin{array}{c}R-8 \\
(h P a . s / L)\end{array}$ & $\begin{array}{c}X-8 \\
(\text { hPa.s } / L)\end{array}$ & $\begin{array}{c}F D \\
(h P a \cdot s / L)\end{array}$ & $\begin{array}{c}f_{0} \\
(H z)\end{array}$ \\
\hline $\begin{array}{r}\text { FVC (L) } 1990 \\
1995\end{array}$ & $\begin{array}{l}-0.22 * * \\
-0.22 * *\end{array}$ & $\begin{array}{l}0.35 \text { *** } \\
0.29 * *\end{array}$ & $\begin{array}{l}0.27^{*} \\
0.26^{*}\end{array}$ & $\begin{array}{l}-0.26^{* *} \\
-0.22 * *\end{array}$ \\
\hline 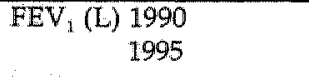 & $\begin{array}{l}-0.30 * * \\
-0.27^{* *}\end{array}$ & $\begin{array}{l}0.36 * * \\
0.32 * *\end{array}$ & $\begin{array}{l}0.33^{* *} \\
0.32^{* *}\end{array}$ & $\begin{array}{l}-0.26^{* *} \\
-0.23^{* *}\end{array}$ \\
\hline $\begin{array}{r}\mathrm{FEV}_{1} / \mathrm{FVC}(\%) \\
1990 \\
1995\end{array}$ & $\begin{array}{l}-0.17^{*} \\
-0.12\end{array}$ & $\begin{array}{l}0.07 \\
0.12\end{array}$ & $\begin{array}{l}0.14 \\
0.16\end{array}$ & $\begin{array}{l}-0.06 \\
-0.06\end{array}$ \\
\hline $\begin{array}{r}\mathrm{PEF}(\mathrm{L} / \mathrm{s}) 1990 \\
1995\end{array}$ & $\begin{array}{l}-0.15 \\
-0.12\end{array}$ & $\begin{array}{l}0.09 \\
0.15\end{array}$ & $\begin{array}{l}0.11 \\
0.04\end{array}$ & $\begin{array}{l}-0.07 \\
-0.14\end{array}$ \\
\hline $\begin{array}{r}\mathrm{MMEF}(\mathrm{L} / \mathrm{s}) \\
1990 \\
1995\end{array}$ & $\begin{array}{l}-0.29 * * \\
-0.22 * *\end{array}$ & $\begin{array}{l}0.24 \\
0.21\end{array}$ & $\begin{array}{l}0.24 \text { ** } \\
0.25 \text { ** }\end{array}$ & $\begin{array}{l}-0.15 \\
-0.13\end{array}$ \\
\hline & $\begin{array}{c}\Delta R-8 \\
\left(h P_{a} . s / L\right)\end{array}$ & $\begin{array}{c}\Delta X-8 \\
\left(h P_{a, s / L)}\right.\end{array}$ & $\begin{array}{c}\triangle F D-8 \\
(h P a . s / L)\end{array}$ & $\begin{array}{c}\Delta f_{0} \\
(H z)\end{array}$ \\
\hline $\begin{array}{l}\triangle F V C 90-95(\mathrm{~L}) \\
\triangle F E V_{1} 90-95(\mathrm{~L}) \\
\triangle F E V_{1} / F V C 90-95(\%) \\
\triangle P E F 90-95(\mathrm{~L} / \mathrm{Sec}) \\
\Delta M M E F 90-95(\mathrm{~L} / \mathrm{Sec})\end{array}$ & $\begin{array}{l}-0.10 \\
-0.08 \\
0.03 \\
0.00 \\
0.00\end{array}$ & $\begin{array}{c}0.18 \\
0.20 \\
0.02 \\
-0.09 \\
0.70\end{array}$ & $\begin{array}{l}0.02 \\
0.08 \\
0.08 \\
0.02 \\
0.06\end{array}$ & $\begin{array}{l}-0.13 \\
-0.22^{* *} \\
-0.08 \\
0.03 \\
-0.07\end{array}$ \\
\hline
\end{tabular}

$\Delta$ : difference between lung function parameters (1990 minus 1995).

Significances were tested by Pearson's correlation test. * $p<0.05 ; * * ;<0.01$.

For further definitions see legend to Table 2.1. 
Impedance parameters accompanying a (rapid) decline in $F E V_{1}$

To investigate a relationship between longitudinal changes in $F E V_{1}$ and impedance parameters, the total group was divided into 4 groups/quartiles of decline in $\mathrm{FEV}_{1}$ with an approximately equal number of subjects (Table 2.3). The data show that a decline in $\mathrm{FEV}_{1}$ is accompanied by similar changes in other flow volume parameters (FVC, FEV $/ F V C$ ratio, PEF, and MEF). Similarly, impedance parameters in 1995 such as resonance frequency $\left(f_{0}\right)$ and $R 8$ tended to increase in relation to increasing decline in $\mathrm{FEV}_{1}$, whereas X8 and FD tended to decrease. Trends were denominated significant if those with rapid decline in $\mathrm{FEV}_{1}\left(\triangle \mathrm{FEV} \mathrm{F}_{1}>330 \mathrm{~mL} / 5\right.$ years) showed a significant difference (ANOVA, $\mathrm{p}<0.05$ ) compared to the others. This was found for $\mathrm{f}_{0}$ in 1995 , the decline in reactance at 8 $\mathrm{Hz}(\Delta \times 8)$, and the incline in resonance frequency $\left(\Delta \mathrm{f}_{0}\right)$. After correction for age, all longitudinal changes in flow volume parameters $\left(\triangle \mathrm{FVC}, \triangle \mathrm{FEV}, / F V \mathrm{C}_{1} \triangle \mathrm{PEF}\right.$, and $\triangle \mathrm{MMEF}$ ) in the lower quartile of $\triangle \mathrm{FEV}_{1}$ were still significantly different (Logistic regression, all $\mathrm{p}<0.01)$. Flow volume parameters $\left(\triangle F V C, \triangle F E V_{1} / F V C\right.$, and $\triangle M M E F)$ and $\triangle R 8$ in the upper middle quartile of $F E V_{1}$ were no longer significantly different. Interestingly, in a linear regression model, the decline in $\mathrm{FEV}_{1}\left(\Delta \mathrm{FEV} \mathrm{V}_{1}\right)$ was significantly fit $\left(\mathrm{r}^{2}=0.13, \mathrm{p}=0.01\right)$ by a model using age, years of employment, pack-years, $F E V_{1}, R-8, X-8, F D$ and $f_{0}$ at the starting point $\left(\Delta F E V_{1}=\right.$ $-0.70+0.01$ age -0.01 years of employment +0.00 pack-years $+0.12 \mathrm{FEV}_{1}{ }^{\prime} 90+0.02$ $R-8,90-0.09$ X-8 $9_{0}-0.02$ FD $9_{90}-0.01 f_{0}, 90$ ). Similarly, alterations in $f_{0}$ were significantly dependent $\left(r^{2}=0.32, p<0.01\right)$ on age $(b=-0.04)$, years of employment $(b=0.10)$, pack-years $(b=0.03), f_{0}(b=0.61), F_{1}(b=0.11), F V C(b=0.56), P E F(b=-0.02)$ and MMEF $(b=0.62)$ at the starting point. Although there was no significant difference in smoking habits and most of the respiratory symptoms among the four quartiles of $\mathrm{FEV}_{1}$ alteration, the group with rapid decline had more complaints of shortness of breath $(\mathrm{p}<0.05)$.

\section{Exposure and lung function (decline)}

Since the number of individuals with airway obstruction (FEV $1<80 \%$ predicted) was small (6 out of 136), the risk of specific exposures was evaluated using the presence of subjects with rapid decline in $\mathrm{FEV}_{1}$ (upper quartile). Comparison of lung function parameters in 1995 among the different plants (Table 2.4) showed significant airway obstruction $(p<0.01)$ in the bulk/transport workers $(n=14)$ compared to the other groups both based on flow volume $\left(\mathrm{FEV}_{1}\right.$, FVC) and impedance parameters $\left(X 8, f_{0}\right)$. At the start (1990) bulk/transport workers had also lower flow volume parameters $(\mathrm{p}<0.05)$ but impedance parameters were still normal compared to other plants. A decrease in FEV 1 ( 3.40 $\mathrm{L}$ versus $3.86 \mathrm{~L}$ in the rest) in this group is again associated with an increase in $\mathrm{f}_{0}$ $(10.08 \mathrm{~Hz}$ vs. $7.72 \mathrm{~Hz})$ and a decrease in reactance $(-0.05$ vs. $0.19 \mathrm{hPa} . \mathrm{s} / \mathrm{L})$. Phlegm was reported more frequently $(p<0.04)$ in bulk/transport workers $(4 / 10)$ than in the rest of the workers $(11 / 111)$, but no difference in symptoms were found between other groups. No difference in age, smoking or years of employment was noted in this specific group; only one of the bulk/transport workers was initialiy employed in another plant and later transferred to this job, as compared to 28 out of 122 in the rest. No difference in lung function, age or employment 
duration was observed within the other 'risk' groups (acids, maintenance). Maintenance workers, however, had been employed significantly longer (21.6 years, $\mathrm{p}<0.05)$ than the rest of this population $(16.3$ years); they were also slightly older ( 45.1 years, $\mathrm{p}=0.1$ ) than the rest ( 40.3 years). However except for an increased FVC $(\%)$, no lung function differences were observed in the latter group. The relative risks calculated accordingly are shown in table 4. Although the table shows increased values for 3 plants, namely acids (2.14), bulk/transport (1.78) and maintenance (2.13), none of these values was statistically significant.

Table 2.3. Personal characteristics, flow volume, impedance parameters and respiratory complaints of subjects classified into quartiles of decline in FEV

\begin{tabular}{|c|c|c|c|c|c|}
\hline Parameter & $\begin{array}{c}\text { Group } I \\
n=34\end{array}$ & $\begin{array}{c}\text { Group II } \\
n=35\end{array}$ & $\begin{array}{c}\text { Group III } \\
n=33\end{array}$ & $\begin{array}{c}\text { Group IV } \\
n=34\end{array}$ & $p$ \\
\hline $\begin{array}{l}\text { General } \\
\text { Age (yrs) } \\
\text { Employment(yrs) } \\
\text { Cigarettes (n/day) } \\
\text { Pack-years } \\
\text { Smokers (n) }(\%)\end{array}$ & $\begin{array}{r}37.5 \mathrm{a}) \\
14.4 \pm 7.8 \\
3.8 \pm 8.0 \\
7.5 \pm 9.0 \\
8(23.5 \%)\end{array}$ & $\begin{array}{c}39.4 \\
15.5 \pm 7.7 \\
2.2 \pm 5.8 \\
5.2 \pm 7.1 \\
7(20.0 \%)\end{array}$ & $\begin{array}{c}42.8 b) \\
18.7 \pm 7.6 \\
4.1 \pm 7.1 \\
9.3 \pm 11.4 \\
10(30.3 \%)\end{array}$ & $\begin{array}{c}42.8 \\
18.1 \pm 8.4 \\
4.0 \pm 7.0 \\
9.7 \pm 10.8 \\
11(32.3 \%)\end{array}$ & $\begin{array}{l}0.03 \\
0.08 \\
0.64 \\
0.20 \\
0.62\end{array}$ \\
\hline $\begin{array}{l}\text { Flow Volume } \\
\triangle \mathrm{PVC}(\mathrm{L}) \\
\triangle \mathrm{FEV} / \mathrm{FVC}(\%) \\
\triangle \mathrm{PEF}(\mathrm{L} / \mathrm{s}) \\
\triangle \mathrm{MMEF}(\mathrm{L} / \mathrm{s})\end{array}$ & $\begin{array}{r}-0.10 \pm 0.24 b) \\
0.53 \pm 3.75 b) \\
-0.37 \pm 1.30 b) \\
0.18 \pm 0.42 b)\end{array}$ & $\begin{array}{l}0.07 \pm 0.27 \\
1.53 \pm 3.89 \\
0.09 \pm 1.51 \\
0.48 \pm 0.41\end{array}$ & $\begin{array}{c}0.12 \pm 0.25 \text { a) } \\
3.31 \pm 4.31 b) \\
0.25 \pm 0.99 \\
0.68 \pm 0.55 b)\end{array}$ & $\begin{array}{l}0.29 \pm 0.29 \text { b) } \\
4.60 \pm 4.05 \text { b) } \\
0.78 \pm 1.44 \text { b) } \\
0.89 \pm 0.58 \text { b) }\end{array}$ & $\begin{array}{l}0.00 \\
0.00 \\
0.00 \\
0.00\end{array}$ \\
\hline $\begin{array}{l}\text { Impedance } \\
\text { R8 (hPa.s/L) } \\
\text { X8 (hPa.s/L) } \\
\text { FD (hPa.s/L) } \\
\text { fo (Hz) } \\
\Delta R 8 \text { (hPa.s/L) } \\
\Delta X 8(\text { hPa.s/L) } \\
\Delta F D(h P a . s / L) \\
\Delta \text { fo (Hz) }\end{array}$ & $\begin{array}{r}2.35 \pm 0.68 \\
0.22 \pm 0.35 \\
0.28 \pm 0.56 \\
7.46 \pm 2.61 \\
0.06 \pm 0.68 \\
-0.06 \pm 0.37 \\
0.27 \pm 0.37 \\
-0.01 \pm 3.19\end{array}$ & $\begin{array}{r}2.35 \pm 0.84 \\
0.15 \pm 0.28 \\
0.39 \pm 0.65 \\
7.77 \pm 2.98 \\
-0.06 \pm 0.49 \\
-0.06 \pm 0.22 \\
0.13 \pm 0.58 \\
0.69 \pm 2.24\end{array}$ & $\begin{array}{c}3.31 \pm 4.89 \\
0.16 \pm 0.27 \\
0.13 \pm 0.54 \\
7.77 \pm 2.21 \\
-1.14 \pm 4.82 \mathrm{a}) \\
0.00 \pm 0.20 \\
0.39 \pm 0.60 \\
-0.40 \pm 2.90\end{array}$ & $\begin{array}{c}2.67 \pm 0.89 \\
0.11 \pm 0.29 \\
0.25 \pm 0.74 \\
8.86 \pm 3.83 a) \\
-0.34 \pm 0.57 \\
0.07 \pm 0.23 a) \\
0.26 \pm 0.75 \\
-1.61 \pm 3.34 b)\end{array}$ & $\begin{array}{l}0.35 \\
0.53 \\
0.40 \\
0.23 \\
0.18 \\
0.10 \\
0.47 \\
0.01\end{array}$ \\
\hline $\begin{array}{l}\text { Complaints } \\
\text { Cough (n) }(\%) \\
\text { Phlegm (n) }(\%) \\
\text { Wheezing }(\mathrm{n})(\%) \\
\text { Shortness of } \\
\text { breath(n) }(\%)\end{array}$ & $\begin{array}{c}4(11.76 \%) \\
3(8.82 \%) \\
6(17.64 \%) \\
5(14.70 \%)\end{array}$ & $\begin{array}{c}2(5.71 \%) \\
2(5.71 \%) \\
8(22.85 \%) \\
3(8.57 \%)\end{array}$ & $\begin{array}{c}6(18.18 \%) \\
7(21.21 \%) \\
8(24.24 \%) \\
10(30.30 \%)\end{array}$ & $\begin{array}{c}2(5.88 \%) \\
3(8.82 \%) \\
6(17.64 \%) \\
11(32.35 \%)\end{array}$ & 0.03 \\
\hline
\end{tabular}

Values are presented as mean $\pm S D$.

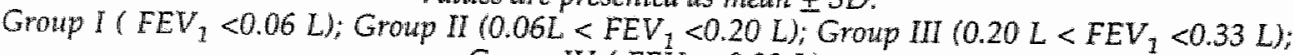
Group IV (EEV $\left.V_{1}>0.33 \mathrm{~L}\right)$.

$\Delta$ signs denote the differences between hung function parameters (1990 mimus 1995).

Significances were tested by one-und ANOVA and tested between a specific group oersus the other groups. If significant : al $p<0.05, b) p<0.01$. 


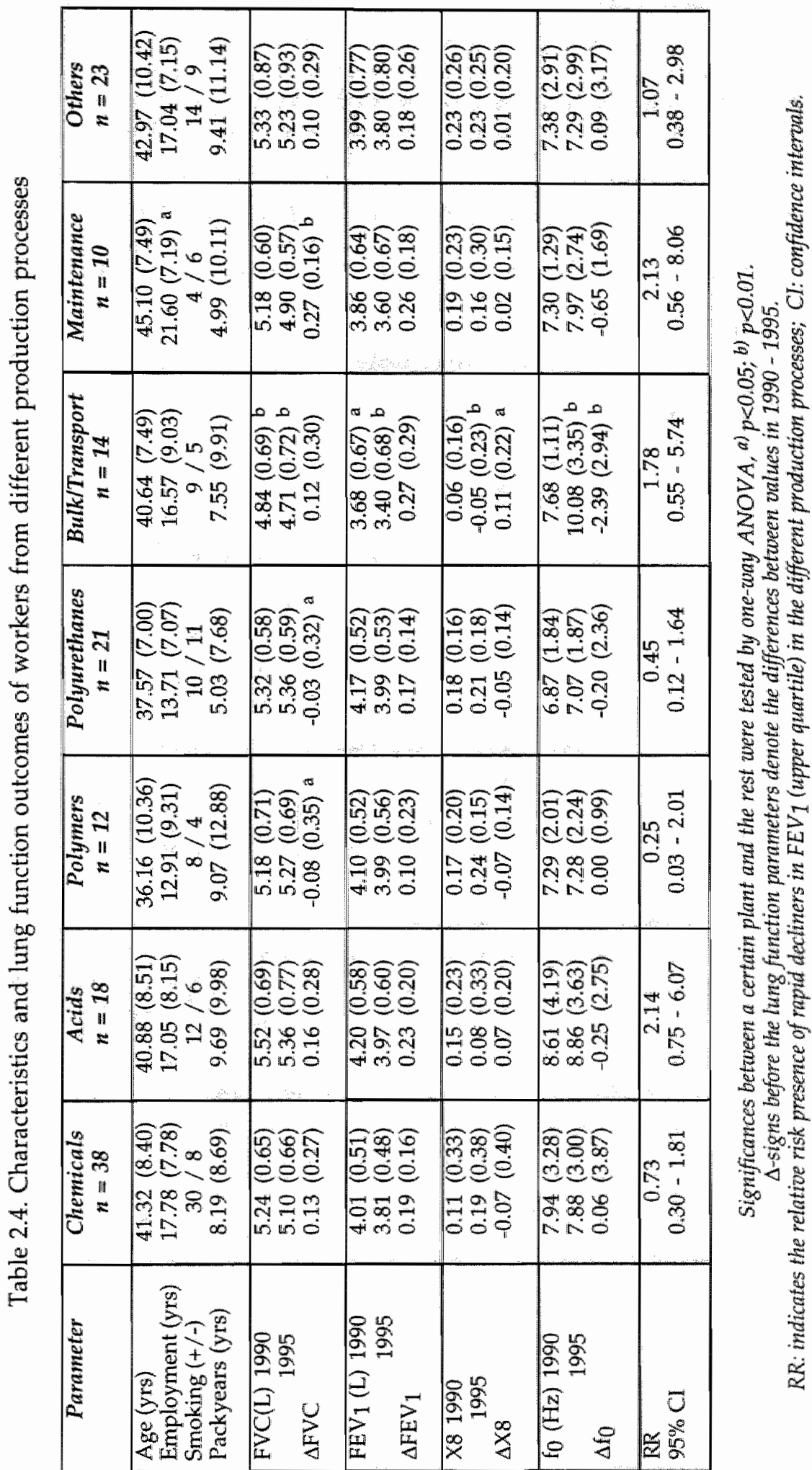


Smoking and lung function

The effect of smoking on lung function was tested by one-way analysis of variance (ANOVA) among current smokers, ex-smokers and nonsmoker (Table 2.5). Interestingly, the data show significant differences $(p<0.01)$ in most flowvolume $\left(\mathrm{FEV}_{1}, \mathrm{FEV}_{1} / \mathrm{FVC}\right.$ and MMEF) parameters and only one impedance parameter (FD, $p<0.05$ ) between these groups. Moreover, the current smokers showed significantly lower FEV $(p<0.05), F_{1} V_{1} / F V C$ Ratio $(p<0.01), P E F(p<0.05)$ and MMEF $(\mathrm{p}<0,01)$ compared to ex- and nonsmoker. The current and exsmokers also showed a significant decrease in FVC ( $<<0.05), \mathrm{FEV}_{1}, \mathrm{FEV}_{1} / \mathrm{FVC}$ ratio, and MMEF (all $\mathrm{p}<0.01$ ) compared to nonsmokers. Furthermore, nonsmokers have a lower decline in $\mathrm{FEV}_{1}$ compared to ex- and current smokers, although the difference was not statistically significant $(p=0.28)$. Impedance parameters revealed a similar pattern with smoking habits, although only frequency dependence was significantly different between groups. Current and ex-smokers had significantly lower FD $(\mathrm{p}<0.05)$ than nonsmokers.

Table 2.5. Influence of smoking habits on lung function parameters (1995)

\begin{tabular}{|c|c|c|c|c|}
\hline Parameter & $\begin{array}{c}\text { Current Smokers } \\
\quad N=36 \\
\end{array}$ & $\begin{array}{c}\text { Ex-Smokers } \\
N=51\end{array}$ & $\begin{array}{c}\text { Non-Swokers } \\
N=49\end{array}$ & $p$ \\
\hline $\begin{array}{l}\text { Flow Volume } \\
\text { FVC (L) } \\
\mathrm{FEV}_{\mathrm{I}}(\mathrm{L}) \\
\mathrm{FEV}, / \mathrm{FVC}(\%) \\
\mathrm{PEF}(\mathrm{L} / \mathrm{Sec}) \\
\mathrm{MMEF}(\mathbb{L} / \mathrm{Sec}) \\
\triangle \mathrm{FEV}_{1}(\mathrm{~L})\end{array}$ & $\begin{array}{c}5.11 \pm 0.84 \\
3.63 \pm 0.71 \mathrm{a}) \\
71.02 \pm 7.74 \mathrm{~b}) \\
8.25 \pm 1.56 \mathrm{a}) \\
2.74 \pm 1.00 \mathrm{~b}) \\
0.24 \pm 0.22 \\
\end{array}$ & $\begin{array}{r}5.01 \pm 0.64 \\
3.37 \pm 0.49 \\
73.98 \pm 5.25 \\
8.67 \pm 1.58 \\
3.05 \pm 0.83 \\
0.19 \pm 0.18 \\
\end{array}$ & $\begin{array}{c}5.34 \pm 0.72 \mathrm{c}) \\
4.07 \pm 0.61 d) \\
76.46 \pm 4.72 d) \\
8.93 \pm 1.20 \\
3.60 \pm 0.93 d) \\
0.17 \pm 0.22\end{array}$ & $\begin{array}{l}0.07 \\
0.00 \\
0.00 \\
0.10 \\
0.00 \\
0.28\end{array}$ \\
\hline $\begin{array}{l}\text { Impedance } \\
\text { R8 (hPa.s } / \mathrm{L}) \\
\text { X8 (hPa.s/L) } \\
\text { FD (hPa.s/L) } \\
\mathrm{f}_{0}(\mathrm{~Hz}) \\
\end{array}$ & $\begin{array}{l}3.25 \pm 4.71 \\
0.21 \pm 0.37 \\
0.18 \pm 0.63 \\
7.57 \pm 2.88\end{array}$ & $\begin{array}{l}2.55 \pm 0.71 \\
0.13 \pm 0.28 \\
0.16 \pm 0.63 \\
8.12 \pm 3.04\end{array}$ & $\begin{array}{l}2.36 \pm 0.79 \\
0.16 \pm 0.26 \\
0.44 \pm 0.59 c) \\
8.09 \pm 3.04\end{array}$ & $\begin{array}{l}0.25 \\
0.47 \\
0.05 \\
0.65\end{array}$ \\
\hline
\end{tabular}

Values are presented as mean \pm SD. Significances were tested by one-way ANOVA.

For definitions see legend to table 1 and 2 .

Significant difference between current smokers vs, ex and non smokers, $" p<0.05 ;{ }^{b} p<0.01$.

Significant difference between non smokers ws. current and ex-smokers, ${ }^{c l} p<0.05 ;{ }^{d)} p<0.01$.

\section{Discussion}

To our knowledge, this is the first report presenting follow-up data on impedance measurements in an occupational setting. We showed that most flow volume and some impedance parameters changed significantly over a five-year interval, and that alterations in impedance parameters reflect changes in flow volume curves longitudinally. These data can be regarded as a valuable 
extension to the results found in cross-sectional studies in occupational settings. Although this study was no attempt to validate the forced oscillation technique versus flow-volume measurements, it showed that in a population with normal changes in flow volume parameters, changes in impedance parameters although not always significant, followed these alterations as predicted by the model interpretation according to Wouters (1990). The lack of longitudinal significance is probably explained by the larger short term and long term variability in FOT derived parameters. A previous study in a small group $(n=10)$ of grain workers showed similar outcome at 2-year follow-up (Borm et al., 1996). Individual repeatability of R8 in our hands was slightly better compared to data published by Neild et al (1989) for $\mathrm{Z}_{3 \mathrm{~Hz}}(11.3 \%)$, or Stanescu et al (1975) for $\mathrm{R}_{3-9 \mathrm{~Hz}}(12.0 \%)$ for short-term variability. Our coefficients of variation for R8 $(10.5 \%)$, X8 (14.6\%), and $f_{0}(14.3 \%)$ would allow minimal detectable changes much smaller than those observed over five years in this cohort. This probably means that long-term variation is larger in impedance than flow volume parameters. This is in agreement with lower sensitivity of forced oscillation technique compared to flow volume. Although a high variability is present in frequency dependence, it is very sensitive parameter to detect airway obstruction. This is, however, not based on the exact value, but upon the difference between a negative (airway obstruction) and a positive (normal) value.

A rapid decline in $F V_{1}$ was reflected in a significant increase in resonance frequency $\left(\mathrm{f}_{0}\right)$ and a significant decrease in reactance at $8 \mathrm{~Hz}(X 8)$. Meanwhile, resistance at $8 \mathrm{~Hz}$ increased considerably and frequency dependence decreased slightly. Cauberghs et al (1993) studied lung function during a follow-up of members of the Belgian Air Force and found no significant alterations in impedance parameters, and found Dlco, $\mathrm{FEV}_{1} / \mathrm{FVC}$ ratio and weight as predictors of a rapid decline in lung function. In our study, initial flow volume parameters together with age, packyears and years of employment are the most important predicting factors of alterations in impedance parameters. Otherwise, initial impedance values together with age, packyears and years of employment were also predictors of longitudinal decline in $\mathrm{FEV}_{1}$. A possible explanation for this finding might be that we used more sensitive parameters like $R 8$ and $X 8$ as opposed to total resistance and total reactance by Cauberghs et al (1993). Since airflow limitation is reflected by an increase in resistance and a decrease in reactance predominantly at lower frequencies (Ying et al., 1990; Wouters, 1990), total resistance and total reactance might introduce a significant amount of noise. Our follow-up study shows that airflow obstruction is a reversible process in this group of workers, and the results show that reversibility is more frequently observed with impedance measurements. This suggests that although changes in the outcome of both techniques are correlated, partly different things are being measured. This is illustrated first by the correlation coefficients of lung function parameters between both time points, which is much lower for impedance measurements (0.23-0.53) than for flow-volume parameters (0.61-0.94). Secondly, correlations between both flow-volume and impedance measurements are consistent (Table 2.2) but low. A similar finding was reported in workers from a gas manufacturing plant (Brochard et all, 1989). Interestingly, these correlation coefficients are much lower than those reported in asthmatics, where usually 
correlation coefficients up to 0.8 are observed (Wouters et al., 1989). Thirdly, changes in impedance parameters among subgroups classified with respect to decline in $\mathrm{FEV}_{1}$ are in line with model considerations (Wouters, 1990) but statistical significance remains limited to resonance frequency (Table 2.3 and 2.4). Finally, similar to other studies Kjeldgaard et al., 1976; Hayes et al., 1984), only frequency dependence is different between (ex) smokers and nonsmokers, while almost all flow volume parameters differ between these groups.

The relative risk to airway obstruction due to specific exposures was evaluated using data on lung function at follow-up and its decline during follow-up, since the number of obstructive subjects ( $\mathrm{FEV}_{1}<80 \%$ ) was too small. Our analysis showed a relative excess of rapid decliners among maintenance workers, bulk/transport workers and workers in the acid-producing plants. Confidence intervals, however, are wide due to the small size of the cohort and therefore relative risks are not statistically significant. Interestingly only in bulk/transport workers, average lung function data (both impedance and flowvolume) were significantly different from the other groups. This result is unlikely to be the effect of selection and transfer of unhealthy workers from other plants, as showed by the internal transfer data (data not shown). Confounding by smoking is also unlikely; first, no differences in smoking habits were noted between different groups. Secondly, the impedance parameter mostly affected by smoking, i.e., frequency dependence (Table 2.5), is not changed in bulk transport workers. Reversely, reactance at $8 \mathrm{~Hz}(X 8)$ and $\mathrm{f}_{0}$ which are not affected by smoking were significantly different in this group. Our findings in bulk/transport workers are probably explained by their high exposure to 'inert' NPK-dust $\left(5-25 \mathrm{mg} / \mathrm{m}^{3}\right)$ present in the fertilizer production unit. These outcomes fit very well a previous cross-sectional study in potato sorters exposed to high concentrations of inert dust $\left(6.9-13.3 \mathrm{mg} / \mathrm{m}^{3}\right)$, being diatomaceous earth (Jorna et al., 1994-c). Also in that study, a higher of $R 8$ and $f_{0}$ were observed and a lower $\mathrm{FEV}_{1}, \mathrm{MMEF}$, and $X 8$ in exposed workers compared to controls. Findings in maintenance and acid producing workers, are probably explained by their typical exposure pattern, consisting of single peak exposures to irritants and vapors during (un)loading, fitting and repair. It has been reported that intermittent peak exposures to airway irritants can cause airways hyperresponsiveness (Brooks and Kalica, 1987) and that the number of peak exposures can be a better descriptor of lung function (Tornling et al., 1990) the average exposure. A recent study on airways hyperresponsiveness in 688 male workers exposed to low level's irritants (Kremer et al., 1995) showed a lower prevalence of airway hyperresponsiveness (AHR) in subjects with less than 5 years exposure to $\mathrm{SO} 2$ and oil mist, probably due to pre-employment screening. No association between AHR and low grade exposure to irritants, however, could be established. Brochard et al (1987) observed normal flow volume curves but altered impedance values in a group of 36 workers exposed to respiratory irritants ( $>6$ years) in gas manufacturing plant compared to the outcome of 46 non-exposed references ( $<6$ years' employment) from the same plant. In our cohort not enough subjects with less than 5 years of employment were present but a similar analysis using 7 years as a cut off revealed a significant difference $(p<0.05)$ in $X 8, F D$ and $f_{0}$ in nonsmoking workers $(n=15)$ with less than 7 years of employment toward a similar group $(n=34)$ employed for more than 7 years. No 
differences in flow volume parameters were present between these groups (data not shown).

We conclude that although the forced oscillation technique is less sensitive compared to forced expiratory flow volume measurements, it is a useful method to screen airway obstruction in this type of occupational exposure. Longitudinal changes in impedance parameters and effects of smoking and occupational exposure reflect or parallel changes in spirometric indices. A widespread application in occupational medicine will teach us the FOT's additional value in specific exposures.

\section{Acknowledgements}

The authors are seriously indebted to all workers for their participation in this study and to $G$. Sambaer for his assistance in flow volume measurements and data retrieval. The authors also thank Tim HJM Jorna, Rael PF Schins, and Tinka Pijls for their assistance in the innedance measurement and data entry. Soedjajadi Keman MD. is a fellow supported by the Indonesian SUDR project.

\section{References}

Borm PJA, Schins RPF, Derhaag TJMM, Kant IJ, Jorna TJM (1996) Cross-shift changes in blood inflammatory markers occur in the absence of airway obstruction in workers exposed to grain dust. Chest 109:1078-1085.

Brochard L, Pelle G, Palmas J de, Brochard P, Carre A, Lorino H, Harf A (1987) Density and frequency dependence of resistance in early airway obstruction. Am Rev Respir Dis $135: 579-584$.

Brooks SM, Kalica AR (1987) Strategies for elucidating the relationship between occupational exposures and chronic airflow obstruction. Am Rev Respir Dis 13:268-273.

Cauberghs M, Clement J, Van de Woestijne KP (1993) Functional alterations accompanying a rapid decline in ventilatory function. Am Rev Respir Dis 147:379-384.

Hayes DA, Pimmel RL, Fulton JM, Bromberg PA (1984) Cold air as bronchial provocation technique. Chest 86:810-814.

Jorna THIM, Borm PJA, Maestrelli P, Fabbri LM, Wouters EFM (1993) Localization of airway obstruction by impedance measurement in isocyanate induced asthmatic reactions. Am Rev Respir Dis 147:A115.

Jorna THIM, Borm PJA, Wesseling GJ, Wouters EFM (1994-a) Application of the forced oscillation technique (FOT) in different occupational settings. Eur Respir Rev 4:19, 155-158.

Jorna THJM, Borm PJA, Valks J, Houba R, Wouters EFM (1994-b) Respiratory symptoms and lung function in animal feed workers. Chest 106:1050-1055.

Jorna THJM, Borm PJA, Koiter KD, Slangen JJM, Henderson P, Wouters EFM (1994-c) Respiratory effects and serum type III procollagen in potato sorters exposed to diatomaceous earth. Int Arch Occup Env Health 66:217-222. 
Kjeldgaard JM, Hyde RW, Speers DM, Reichert WW (1976) Frequency dependence of total respiratory resistance in early airway disease. Am Rev Respir Dis 114:501-508.

Kremer AM, Pal TM, Schouten IP, Rijcken B (1995) Airway hyperresponsiveness in workers exposed to low levels of irritants. Eur Respir ] 8:53-61.

Landser FJ, Nagels J, Demedts M, Billiet L, Van de Woestijne KP (1976) A new method to determine frequency characteristics of the respiratory system. I Appl Physiol 41:101-106.

Neild JE, Twort CHC, Chinn S, McCormack S, Jones TD, Burney PGJ, Cameron IR (1989) The repeatibility and validity of respiratory resistance measured by the forced oscillation technigue. Respir Med 83:111-118.

Orehek J, Nicoli MM, Delpierre S, Beaupré A (1981) Influence of the previous deep inspiration on the spirometric measurement of provoked bronchoconstriction in asthma. Am Rev Respir Dis 123:269-272.

Pairon JC, Iwatsubo $Y$, Hubert $C$, Lorino $H$, Nouaigui $H$, Gharbi $\mathbb{R}$, Brochard $P$ (1994) Measurement of bronchial responsiveness by forced oscillation technique in occupational epidemiology. Eur Respir J 7:484-489.

Pham QT, Bourkard E, Chau N, Willim G, Megherbi SE, Tecullescu D, Bohadana A, Bertrand IP (1995) Forced oscillation technique (FOT): a new tool for epidemiology of occupational lung diseases? Eur Respir [ 8:1307-1313.

Quanjer PhH (1983) Standardized lung function testing Bull Eur Physiopathol Respir 19 (Suppl. 5):1-95.

Stanescu DC, Fesler R, Variter C, Fans A, Brasseur L (1975) A modified measurement of respiratory resistance by forced oscillation during normal breathing. I Appl Physiol 39:305311.

Tornling $G$, Alexandersson $\mathbb{R}$, Hendenstierna $G$, Plato $N$ (1990) Decreased lung function and exposure to diisocyanates (HDI and HDI-BT) in car repair painters: observations on reexamination 6 years after initial study. Am I Ind Med 17:299-310.

Wouters EFM, Polko AH, Visser BF (1989) Response localization of the pharmacologica] agents histamine and salbutamol along the respiratory system by forced oscillations in asthmatic subjects. J Asthma 26:185-193.

Wouters EFM (1990) Total respiratory impedance measurement by forced oscillations: a noninvasive method to assess bronchial response in occupational medicine. Exp Lung Res $16: 25-40$.

Ying $Y_{\text {, Peslin }} \mathrm{R}_{*}$ Duvivier $\mathrm{C}$, Gallina C, Da Silva JF (1990) Respiratory input and transfer mechanical impdances in patients with chronic obstructive pulmonary disease. Eur Respir J 3:1186-1192. 


\title{
Chapter 3
}

\section{BLOOD INTERLEUKIN-8 PRODUCTION IS INCREASED IN CHEMICAL WORKERS WITH BRONCHITIC SYMPTOMS}

\author{
Soedjajadi Keman $M D^{1}$, Brigitte Willemse $B S c^{2}$, David J. Tollerud $M D, M P H^{2}$. \\ Lucille Guevarra ${ }^{2}$, Roel P.F. Sohins PhD', and Paul J.A. Borm PhD1. \\ ${ }^{1}$ Deparment of Health Risk Analysis \& Toxicology, Maastricht University, \\ Maastricht, The Netherlands. \\ ${ }^{2}$ Department of Environmental and Occupational Health, \\ Graduate School of Public Health, University of Pittsburgh, \\ Pittsburgh, Pennsylvania, USA.
}

\begin{abstract}
Chemical exposure may result in respiratory conditions such as chronic bronchitis, bronchial hyperresponsiveness, and chronic airway obstruction. Clinical studies have shown that during the course of disease, cytokine networks are changed. In order to study the relationship between blood cytokines and respiratory symptoms or lung function in an occupational setting, we investigated 106 chemical workers during a routine yearly medical examination in 1995. Lung function was measured with flow volume curves and impedance using the forced oscillation technique (FOT). Smoking status and respiratory symptoms were determined by questionnaires. Cytokines were selected on biological plausibillity and measured both in a whole blood assay (TNF- $\alpha$, IL-8) and in serum (IL-4, IL-5, IL-6, IFN- $\gamma$ ). Exposure data were retrieved from the year 1994/1995 of the company's chemical safety database. The hypothesis is that blood levels of TNF- $\alpha$ and IL- 8 are increased in bronchitis, while serum levels of IL4, IL-5 are increased and IFN- $\gamma$ is decreased in asthmatic workers.

Spontaneous $\mathrm{IL}-8$ release was significantly higher in workers with bronchitis $(p<0.05)$ or chronic bronchitis $(p<0.01)$ compared to workers without those respiratory symptoms, also after correction for age, pack-years, and blood lymphocyte numbers or compared to a matched control group. No correllation was present between specific cytokines and asthmatic symptoms, lung function, or chronic airway obstruction; serum IL-5 was significantly correlated $(p<0.05)$ to age and pack-years, and blood TNF- $\alpha$ rellease was significantly higher $(p<0.05)$ in non-smokers compared to (past and current) smokers. Moreover, lung function was significantly lower $(p<0.01)$ and serum IL -4 was significantly increased $(p<0.05)$ in workers exposed to fertilizer dust.

These data suggest that blood IL-8 may be considered as a useful marker for bronchitis. With increasing age and cigarette smoking, the ability and capacity to produce certain cytokines tends to decrease. Apart from $I L-8$ and $1 L-4$ that were associated to bronchitis and airway obstruction related to high-dust exposure, the data do not support the widespread use of blood cytokines as a tool for screening in occupational practice.
\end{abstract}

Accepted for publication on 14 July 1997 in:

American Journal of Industrial Medicine (Modified version). 


\section{Introduction}

Chemical exposure can lead to obstructive airway disease such as (acute and chronic) bronchitis and also can induce bronchial hyperresponsiveness (Becklake, 1989; Kennedy, 1992). During the course of these diseases, cytokine networks invoked are changed (Kelley, 1993, Kimber and Dearman, 1994). Monocyte derived cytokines such as tumor necrosis factor-alpha (TNF- $\alpha$ ) and interleukin-8 (IL-8) usually denominated as 'proinflammatory' play an important role in local inflammation (Collart et al., 1986). Previously, we demonstrated that TNF- $\alpha$ released by blood monocytes ex-vivo was related to airway obstruction (Jorna et al., 1994), lung function decline (Keman et al., 1995) and dust induced lung fibrosis (Schins and Borm, 1995) in retired coal workers. IL-8 has been shown to be an important chemoattractant found in sputum (Richman-Eisenstat et al, 1993; Keating et al., 1996), in bronchial lavage fluid of patients with chronic bronchitis (Riise et al., 1995), asthma (Chanez et al., 1996) and healthy subjects exposed to ozone (Balmes et al., 1996), and in nasal lavage fluid of asthmatic children (Noah et al., 1995-a), and viral acute upper respiratory infection (Noah et al., 1995-b). IL-8 has been suggested to play an important role in the pathogenesis of neutrophilic airway inflammation in chronic bronchitis or eosinophilic airway inflammation in bronchial asthma (Broaddus et al., 1992; Donelly et al., 1993; Hoshi et al., 1995). In bronchial hyperresponsiveness, especially increases in serum interleukin-4 (IL-4) and interleukin-5 (IL-5) and decrease in interferon- $\gamma$ (IFN- $\gamma$ ) have been reported. An imbalance between IL-4, IL-5, and IFN- $\gamma$ stimulates T helper type $2\left(\mathrm{Th}_{2}\right)$ cell proliferation, which in turn is an important hypothetical mechanism in bronchial hyperresponsiveness and asthma (Holtzman et al., 1996). In the acute response to inflammation, serum interleukin-6 (IL-6) has been implicated as a regulatory cytokine, and an exaggerated IL -6 response has been associated with many adverse clinical events (Zitnick and Elias, 1993). We hypothesize that blood levels of TNF- $\alpha$ and IL-8 are increased in chronic bronchitis, while serum levels of IL-4, IL-5 are increased and IFN- $\gamma$ is decreased in workers with asthmatic symptoms.

Data on these cytokines in obstructive airway diseases are typically generated in clinical studies, using bronchoalveolar lavage, nasal lavage or sputum (cf. Keating et al, 1996). In this study we evaluated these cytokines in 106 workers during a regular health screening, and in addition peripheral blood was used as a matrix for assessment of cytokines. More specifically, the aims of this study were: (i) to relate occupational exposure to blood cytokine changes; (ii) to relate blood cytokines to respiratory symptoms and airflow obstruction.

\section{Methods}

\section{Study Design}

This study was designed as a cross-sectional study among male workers from a large chemical plant. Participants recruited for routine yearly medical examination in April and May 1995 were included in this study. Written 
informed consent was obtained from each worker after evaluation of a selfadministered questionnaire on respiratory symptoms, smoking habits and additional questions concerning working history. All subjects completed three impedance measurements and three flow volume curves. Two blood samples (10 $\mathrm{ml}$ heparinized and $5 \mathrm{ml}$ EDTA-ized) were taken from each worker for blood and serum cytokine assay. Finally 106 complete data sets of questionnaires, lung function measurements and blood samples were obtained and analyzed. Worker information and monitoring exposure data were available for six (various chemicals, acids, polymers, polyurethanes, bulk/transport, and technical service) production processes from the company"s chemical safety database 1994/1995, and are shown in table 3.1 .

\section{Lung Function Measurements}

Impedance measurements were always performed before flow volume curves to avoid the influence of forced inspiratory maneuvers on bronchial tone (Orehek et al., 1981). Impedance of the respiratory system was measured using the forced oscillation technique (FOT) described by Làndsér et al (1976). The seated subject, wearing a noseclip, supports the cheeks with his hands and breathes quietly via a tube. A pseudo-random noise pressure signal containing all harmonics of $2 \mathrm{~Hz}$ from 4 to $48 \mathrm{~Hz}$ was applied at the mouth by means of a loudspeaker. Recorded pressure and flow signals were analyzed by spectral analysis techniques. Mean values of three successive measurements, each lasting 8 seconds were used in the analysis. Of the obtained impedance data, the resistance at $8 \mathrm{~Hz}(\mathrm{R} 8)$, at $28 \mathrm{~Hz}$ ( $\mathrm{R} 28$ ), the difference between $\mathrm{R} 28$ and $\mathrm{R} 8$ (frequency dependence (FD), signifying the course of the resistance versus frequency curve), the reactance at $8 \mathrm{~Hz}(\times 8)$ and the resonant frequency $\left(f_{0}\right)$ were used for analysis. R8 was chosen because at this frequency usually coherence function $>0.95$ was obtained, which was not always obtained at lower frequencies. A negative FD and a resonance frequency $\left(f_{0}\right)$ exceeding $15 \mathrm{~Hz}$ were regarded as indicative for airflow limitation. The equipment was calibrated twice daily and all measurements were performed using the same apparatus by the same investigator.

Forced expiratory flow volume curves were performed as described previously (Keman et al., 1996) and recorded according to European Community for Steel and Coal (ECSC) criteria using a Vicatest P1 dry spirometer (Mijnhardt, Bunnik, The Netherlands). Three recordings of forced vital capacity within $5 \%$ or a $100 \mathrm{ml}$ range were obtained from each subject. Parameters derived from the flow volume curves were: forced vital capacity (FVC), forced expiratory volume in 1 second $\left(\mathrm{FEV}_{1}\right), \mathrm{FEV}_{1} / \mathrm{FVC}$ ratio, peak expiratory flow volume (PEF), and maximal mid expiratory flow volume (MMEF). All flow volume values were related to the reference values of the ECSC (Quanjer, 1983) for individual diagnosis. Values less than $80 \%$ of the predicted values of $\mathrm{FEV}_{1}$ reflected subjects with airway obstruction. The spirometer was calibrated two times daily and all subjects were measured on the same spirometer by the same investigator.

\section{Respiratory Symptoms.}

Respiratory symptoms were diagnosed based on the answers of each participant in the questionnaire. The questionnaire is adapted from the British 
Medical Research Council (BMRC) standardized questionnaire on respiratory symptoms, smoking habits and additional questions concerning working history. Bronchitis was diagnosed as productive cough after waking up, during smoking, and/or productive cough during the winter season. Chronic bronchitis was diagnosed if the above complaints were present in most days for at least 3 months in the year for at least 2 successive years. Asthma was diagnosed on the basis of symptoms of shortness of breath and wheezing.

\section{Cytokine Assays}

Two blood samples were taken from each worker using a $10 \mathrm{ml}$ heparin vacuum tube $(5 \mathrm{U} / \mathrm{ml}$, LEO Pharmaceutical Products BV, Weesp, The Netherlands) prepared aseptically in our laboratory and a $5 \mathrm{ml}$ EDTA vacuum tube. EDTA treated blood samples were used for haemocytometry (Coulter JT, Analys-Namen, Belgium) and subsequently centrifuged $\left(600 \mathrm{~g}, 4{ }^{\circ} \mathrm{C}, 5 \mathrm{~min}\right)$ for storage of serum at - $80^{\circ} \mathrm{C}$ until cytokine assays.

The whole blood assay was described previously (Schins et al., 1996). Briefly, two $1 \mathrm{ml}$ portions of the heparinized blood $(10 \mathrm{ml})$ are transferred into 2 vacuum reagent tubes containing $1 \mathrm{ml} \mathrm{RPMI}$ culture medium (GIBCO Life, Paisley UK) for spontaneous blood cytokine (TNF- $\alpha$ and IL-8) release. The duplicate test tubes were incubated in a shaking water bath 40 times per minute at $37{ }^{\circ} \mathrm{C}$, under an angle of $45^{\circ}$. After 4 hours, all tubes were placed on ice water and after another 3 minutes, all tubes were centrifuged $\left(600 \mathrm{~g}, 4{ }^{\circ} \mathrm{C}, 5 \mathrm{~min}\right)$ and placed on ice water before transfer the supernatants into micronics $3 \times 250 \mu \mathrm{l}$, and stored immediately at $-20^{\circ} \mathrm{C}$ until analysis. Serum cytokine levels of IL-4, IL5, IL-6, and IFN- $\gamma$ were determined using chemiluminescence enzyme-linled immunosorbent assay (ELISA) as described previously (Tollerud et al., 1994). Detection limits were: $2.5 \mathrm{pg} / \mathrm{ml}$ for IL-4, $2 \mathrm{pg} / \mathrm{ml}$ for IL-6, $1.25 \mathrm{pg} / \mathrm{ml}$ for IL-5 and IFN $-\gamma$. Blood release of TNF- $\alpha$, and IL- 8 were determined using specific ELISA as described previously (Biorm et al., 1996; Leeuwenberg et al., 1994). Detection limits were: $30 \mathrm{pg} / \mathrm{ml}$ for TNF- $\alpha$, and $50 \mathrm{pg} / \mathrm{ml}$ for IL-8.

\section{Statistical Analysis}

Pack-years were calculated from the questionnaires, as average weekly of total number of packs of cigarettes smoked multiplied by the number of years smoked. Comparisons of personal characteristics or lung function parameters among production processes were done using one-way ANOVA. Since cytokine data were not normally distributed, all related cytokines statistical analyses were done using nonparametric statistics. Cytokine levels among workers with and without respiratory symptoms, airway obstruction, and smoking were tested using Mann Whitney U or Kruskal Wallis test. A secondary analysis comparing a case group with bronchitis and controls (either as the rest or a group matched with the same age range) was done to verify the specific effects noted in this group. Correlations between cytokine levels and lung function parameters or personal characteristics were tested by Spearman"s rank correlation test. Confounding factors such as age and pack-years which influenced relationship between cytokines and smoking habits, respiratory symptoms, airway 
obstruction, and chemicals exposure were controlled using logistic regression. Probability values $<0.05$ were considered as statistically significant. All procedures were done using SPSS for Windows 6.0 software.

\section{Results}

\section{General Data}

All monitoring data for six production procesess from the company's chemical safety database $1994 / 1995$ were below the Dutch equivalent of threshold limit value (TLV) or maximum allowable concentration (MAC), except for nitrogen, phosphor and potassium (NPP) containing dust exposure during packaging and transporting of crude fertilizers (Table 3.1).

Table 3.1. Exposure of the study group in 6 different production processes

\begin{tabular}{|c|c|c|c|}
\hline $\begin{array}{l}\text { Production } \\
\text { Process }\end{array}$ & $\begin{array}{l}\text { Chemical Exposure } \\
\text { (Agents) }\end{array}$ & $\begin{array}{c}\text { Exposure Data } \\
\text { (range) 1994/1995 }\end{array}$ & $\begin{array}{c}\text { MAC } \\
\left(8 h{ }^{\prime} \text { TWA }\right)\end{array}$ \\
\hline $\begin{array}{l}\text { 1. Various Chemicals } \\
(\mathrm{n}=28)\end{array}$ & $\begin{array}{l}\text { Ethylene Oxide } \\
\text { Amine } \\
\text { Cyclohexanon } \\
\text { Nitric Oxide } \\
\text { Nitric Dioxide } \\
\text { Nitrobenzene } \\
\text { Aniline }\end{array}$ & $\begin{array}{c}0.05-0.12 \mathrm{ppm} \\
0.08-0.30 \mathrm{ppm} \\
0.02-0.08 \mathrm{ppm} \\
0.40-0.70 \mathrm{ppm} \\
0.04-0.80 \mathrm{ppm} \\
0.018-0.02 \mathrm{ppm} \\
0.01-0.07 \mathrm{ppm}\end{array}$ & $\begin{array}{c}50 \mathrm{ppm} \\
5-50 \mathrm{ppm} \\
50 \mathrm{ppm} \\
25 \mathrm{ppm} \\
2 \mathrm{ppm} \\
1 \mathrm{ppm} \\
0.25 \mathrm{ppm}\end{array}$ \\
\hline $\begin{array}{l}\text { 2. Acid Production } \\
(\Omega=15)\end{array}$ & $\begin{array}{l}\text { Sulfur dioxide } \\
\text { Ammonia }\end{array}$ & $\begin{array}{l}0.2-0.4 \mathrm{ppm} \\
1.1-1.9 \mathrm{ppm}\end{array}$ & $\begin{array}{l}2 \mathrm{ppm} \\
25 \mathrm{ppm}\end{array}$ \\
\hline $\begin{array}{l}\text { 3. Polymer/Fiber } \\
\text { Production } \\
(\mathrm{n}=15)\end{array}$ & $\begin{array}{l}\text { Toluene } \\
\text { Winyl Chloride } \\
\text { Ethyl Benzene } \\
\text { Styrene } \\
\text { Benzene } \\
\text { Caprolactam (dust) } \\
\text { Ammonium Sulphate } \\
\text { (dust) }\end{array}$ & $\begin{array}{c}0.02 \mathrm{ppm} \\
0.12-0.97 \mathrm{ppm} \\
0.005-0.06 \mathrm{ppm} \\
0.009-0.01 \mathrm{ppm} \\
0.02-0.82 \mathrm{ppm} \\
0.0002-0.86 \mathrm{mg} / \mathrm{m}^{3} \\
0.0001-3.84 \mathrm{mg} / \mathrm{m}^{3}\end{array}$ & $\begin{array}{l}40 \mathrm{ppm} \\
5 \mathrm{ppm} \\
50 \mathrm{ppm} \\
25 \mathrm{ppm} \\
10 \mathrm{ppm} \\
1 \mathrm{mg} / \mathrm{m}^{3} \\
5 \mathrm{mg} / \mathrm{m}^{3}\end{array}$ \\
\hline $\begin{array}{l}\text { 4. Polyurethowes } \\
(n=17)\end{array}$ & MDI ${ }^{\text {a) }}$ & $0.0005-0.0054 \mathrm{ppm}$ & $0.005 \mathrm{ppm}$ \\
\hline $\begin{array}{l}\text { 5. BulkiTransport *) } \\
(n=11)\end{array}$ & NPP dust & $0.3-257 \mathrm{mg} / \mathrm{m}^{3}$ & $5 \mathrm{mg} / \mathrm{m}^{3}$ \\
\hline $\begin{array}{l}\text { 6. Techntical Service } \\
(\mathrm{n}=20)\end{array}$ & Incidental exposure & $\cdots$ & $\cdots-$ \\
\hline
\end{tabular}

*) According to The Dutch National Maximum Allowable Concentration (MAC) List 1995.

a) $M D I=4,4^{\prime}$-methylenediphenyl di-isocyanate.

*) Workers inwolved in packaging and transporting of crude fertilizers; generated dust containing high antounts of nitrogen, phosphor and potassium (NPP). 


\begin{tabular}{|c|c|c|c|c|c|}
\hline 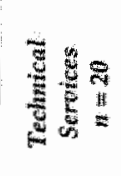 & $\frac{9}{4}$ & $\sum_{i n}^{8}$ & 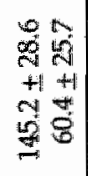 & 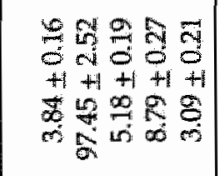 & 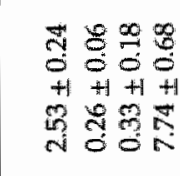 \\
\hline 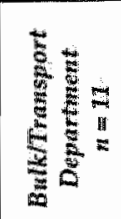 & $\begin{array}{l}\infty \\
0 \\
0 \\
0\end{array}$ & $\sum_{i}^{\infty}$ & 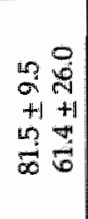 & 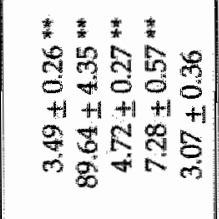 & 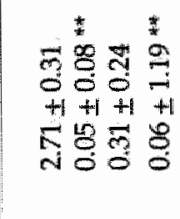 \\
\hline 跣 & $\mathrm{N}_{\mathrm{i}}$ & $\sum_{\infty}^{\infty}$ & 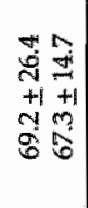 & 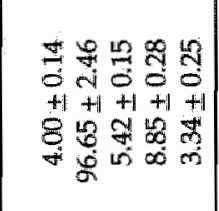 & 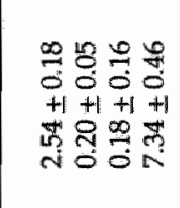 \\
\hline 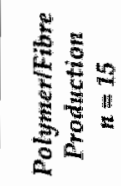 & $\begin{array}{c}m \\
+1 \\
0 \\
m\end{array}$ & $\sum_{i}^{\infty}$ & 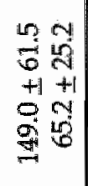 & 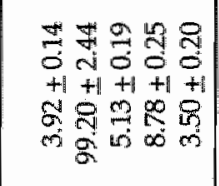 & 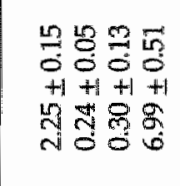 \\
\hline स्: & 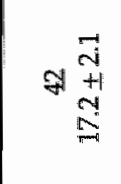 & $\sum_{\infty}^{10}$ & 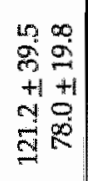 & 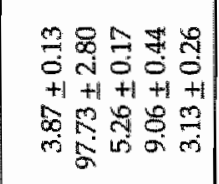 & 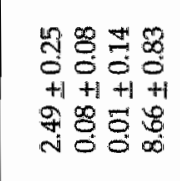 \\
\hline 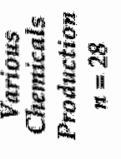 & 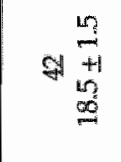 & $\sum_{i}^{+\infty}$ & 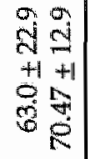 & 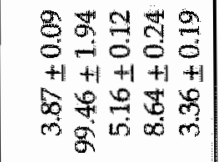 & 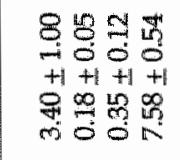 \\
\hline$=\frac{5}{3}$ & की $\begin{array}{c}\infty \\
+1 \\
0 \\
0\end{array}$ & $\sum_{\frac{\pi}{9}}^{\frac{8}{4}}$ & 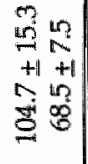 & 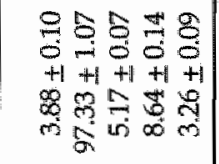 & 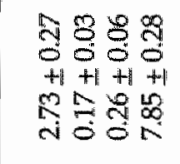 \\
\hline 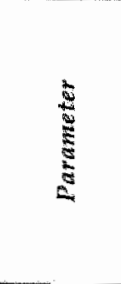 & 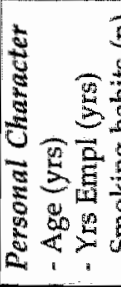 & 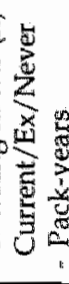 & 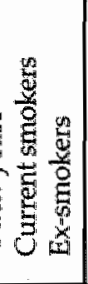 & 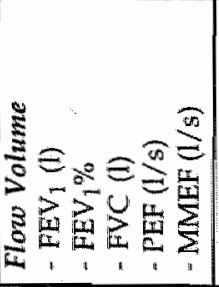 & 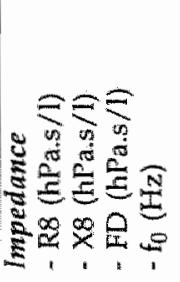 \\
\hline
\end{tabular}

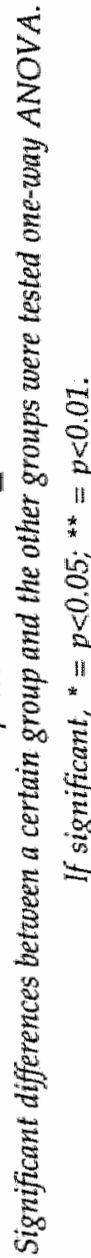


Personal characteristics and lung function data of the 106 male workers and also stratified by different production processes are shown in Table 3.2 . The average age was 40 years (23-59 yrs), average years of employment was 16.6 years (5-29 yrs), and there were 25 current smokers, 42 ex-smokers and 39 nonsmokers. Bronchitis was present in $7(6.6 \%)$ subjects, and chronic bronchitis was present in $5(4.7 \%)$ of these subjects. Asthma was present in $8(7.5 \%)$ subjects. These respiratory symptoms were low probably due to healthy workers effect and distributed evenly over the production processes. Spontaneous release of TNF- $\alpha$ was seen in the whole blood assay for 14 workers (13.2\%).

Interestingly, their serum IL-6 level $(47.70 \mathrm{pg} / \mathrm{ml})$ was significantly higher $(\mathrm{p}<0.05)$ compared to subjects without detectable TNF- $\alpha(29.87 \mathrm{pg} / \mathrm{mll})$, suggesting increased inflammatory activity in this subjects. This effect was not correlated with monocytes number in these subjects Spontaneous IL-8 release was readily detectable in 76 workers $(71.7 \%)$. No clear correlation was present between blood TNF- $\alpha$ and $\Pi-8$ release. Serum cytokines were detectable in all workers. Workers exposed to fertilizer dust (bulk/transport) showed significantly higher (Mann Withey $U$ test, $p<0.05$ ) serum IL-4 compared to the other groups. Furthermore, serum IL-5 was significantly lower in various chemicals production workers $(n=29)$ compared to the other groups $(n=77)$. Apart from these exposures, no relation or changes in cytokines to lung function parameters are found.

Table 3.3. Correlation between cytokines and age, years of employment, and packyears

\begin{tabular}{|c|c|c|c|}
\hline Cytokines & $\begin{array}{l}\text { Age } \\
(y r s)\end{array}$ & $\begin{array}{c}\text { Vrs of Employment } \\
\text { (yrs) }\end{array}$ & Pack-years \\
\hline $\begin{array}{l}\text { Serum (pg/ml) } \\
- \text { IL-4 } \\
- \text { IL-5 } \\
\text { - IL-6 } \\
- \text { IFN- } \gamma\end{array}$ & $\begin{array}{l}-0.15 \\
-0.19 \\
-0.20 \\
-0.16\end{array}$ & $\begin{array}{l}-0.09 \\
-0.15 \\
-0.18 \\
-0.11\end{array}$ & $\begin{array}{l}-0.16 \\
-0.22 \\
0.00 \\
-0.13\end{array}$ \\
\hline $\begin{array}{l}\text { Whole Blood (ng/wnl) } \\
\text { - TNF } \alpha \\
- \text { IL-8 }\end{array}$ & $\begin{array}{r}-0.18 \\
0.06\end{array}$ & $\begin{array}{r}-0.16 \\
0.04\end{array}$ & $\begin{array}{l}-0.20 * \\
-0.05\end{array}$ \\
\hline
\end{tabular}

Significances of correlation were tested by Spearman's correlation test, if significant, ${ }^{*}=p<0.05$.

\section{Effect of Age, Years of Employment, and Smoking}

The relationship between cytokines and personal characteristics was investigated using Spearman's rank correlation test. All serum cytokines and blood TNF- $\alpha$ showed a negative correlation with age and years of employment but this relation only reached significance for serum $\Pi L-5$ and $I L-6(p<0.05)$ to age. Likewise, all cytokines studied showed a negative correlation with pack-years, 
although only blood TNF-a and serum IL-5 level reached a statistical significance (Table 3.3). No significant difference was found in cytokine levels among current, past, and nonsmokers, except for blood TNF- $\alpha$ (Figure 3.1). Non smokers had a significantly higher (Kruskal Wallis, $p<0.05$ ) blood TNF- $\alpha$ compared to past and current smokers, and detectable blood TNF- $\alpha$ levels were observed more frequently in non-smokers $(n=9)$ than past $(n=3)$ and current smokers $(n=2)$.

Figure 3.1.

Cytokine levels in current, past, and non-smokers

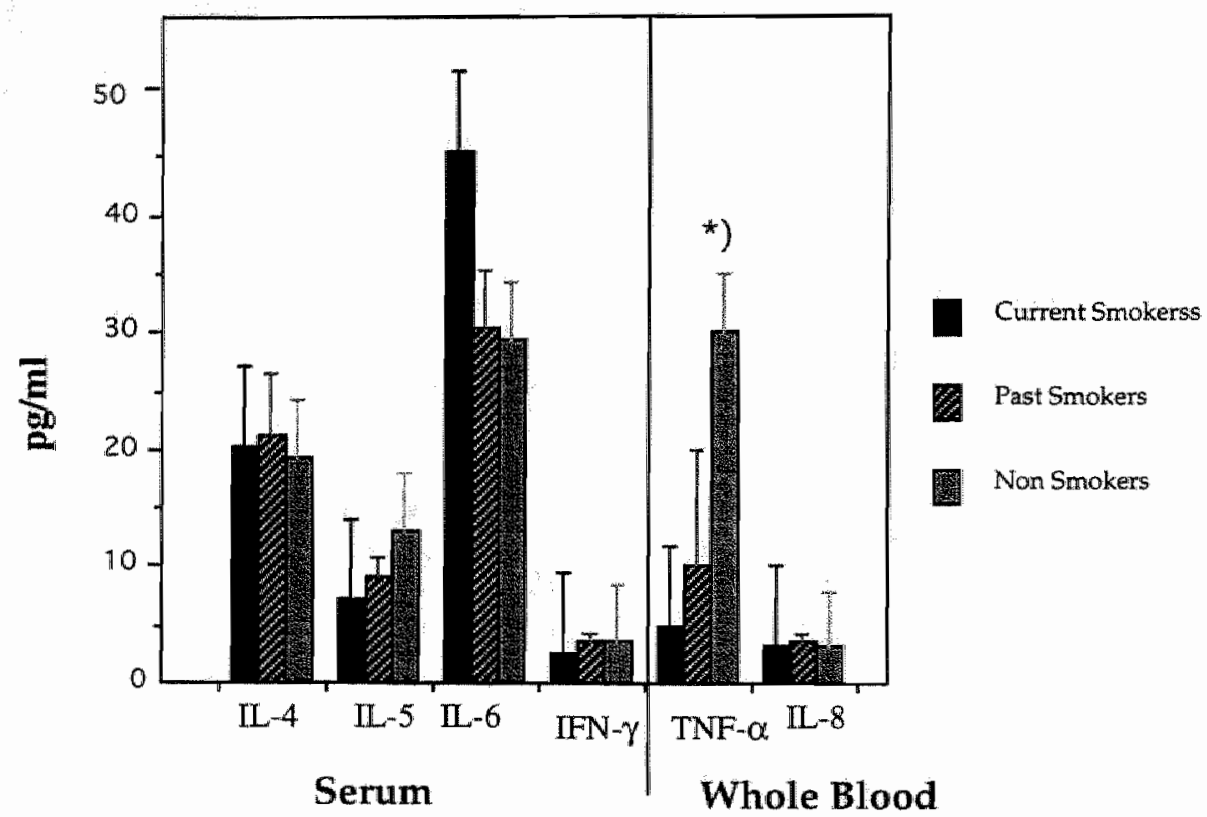

Cytokines (mean $\pm S E M$ ) in current, past, and nonsmokers. Except for spontaneous blood TNF- $\alpha$ production, which is significantly higher in non-smokers (Kruskal Wallis, $p<0.05$ ) compared to past and current smokers, no significances are present. All cytokine units are pg/ml, except spontaneous blood TNF- $\alpha$ which is $\mathrm{ng} / \mathrm{ml}$.

\section{Cytokines and Respiratory Symptoms}

Interestingly, subjects with bronchitic or chronic bronchitic symptoms (Figure 3.2) had a significantly higher blood IL-8 release compared to those with symptoms free (Mann Whitney U-test, $p<0.05 ; \mathrm{p}<0.01$ ). These differences remained significant after correction for age and pack-years (logistic regression, $\mathrm{p}<0.05)$ or number of white blood cells. Reversely, age, pack-years, and 
spontaneous IL-8 release were correlated to bronchitic symptoms in a logistic regression $(p<0.01)$. A secondary analysis comparing a case group of bronchitis and a matched control group (Table 3.4) verified these specific effects; the data show that flow volume parameters (FEV $1, M M E F)$ and FD in the age-matched control group $(n=68)$ are no longer different from subjects with bronchitis, while blood IL-8 release is still increased $(\mathrm{p}<0.05)$ in this group. Interestingly, R8 (but not FD) was still increased in the matched group. No significant differences were present in other serum and blood cytokine levels between workers with and without (acute or chronic) bronchitis, or asthmatic symptoms.

Figure 3.2.

Cytokine level in subjects with (chronic) bronchitis and symptoms free

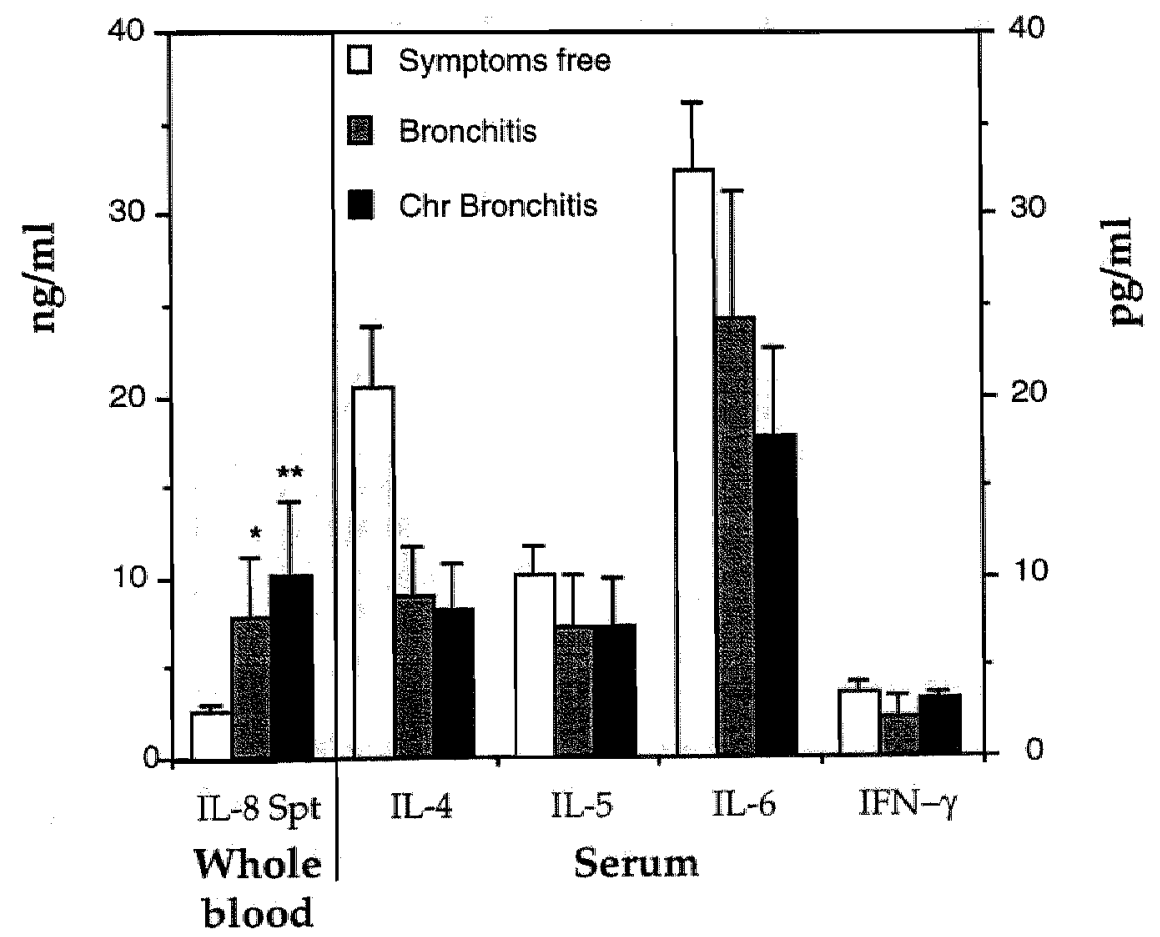

Subjects with bronchitis $(n=7)$ or chronic bronchitis $(n=5)$ have a significantly higher whole blood spontaneous IL-8 release (Mann Whitney U test, $p<0.05 ; p<0.01$ ) compared to those with symptoms free $(n=101)$. These differences remained after correction for age and pack-years (Logistic regression, $p<0.05)$. Conversely, these subject have lower serum cytokine $(I L-4$, IL-5, IL-6, and IFN-y) levels compared to healthy workers, although this did not reach significance.

Values are presented as mean $\pm S E M$. 
Table 3.4. Personal characteristics, lung function and cytokine levels in workers with vs. without bronchitis or (age and sex)-matched controls

\begin{tabular}{|c|c|c|c|}
\hline Paranteter & $\begin{array}{l}\text { With Bronchitis } \\
(n=7)\end{array}$ & $\begin{array}{l}\text { Without Bronchitis } \\
\qquad(n=99)\end{array}$ & $\begin{array}{c}\text { Matched Controls } \\
\qquad(n=68)\end{array}$ \\
\hline $\begin{array}{l}\text { Persanal Characteristics } \\
\text { - Age (yrs) } \\
\text { - Smoking habits (n) } \\
\text { Curtent/Ex-/Non-smokers } \\
\text { - Pack-years } \\
\text { Cument smokers } \\
\text { Ex-smokers }\end{array}$ & $\begin{array}{c}46(34-56) \\
2 / 2 / 3 \\
150.0 \pm 150.0 \\
71.0 \pm 27.1\end{array}$ & $\begin{array}{l}40(23-59) \\
23 / 40 / 36 \\
100.8 \pm 13.7 \\
68.34 \pm 7.8\end{array}$ & $\begin{array}{c}44(34-56) \\
18 / 36 / 14 \\
113.0 \pm 15.6 \\
74.7 \pm 8.0\end{array}$ \\
\hline $\begin{array}{l}\text { Flow Volume } \\
- \text { FEV }_{1}(1) \\
\text { - FEV } \% \text { (\%) } \\
\text { - FVC (l) } \\
\text { - PEF (1/s) } \\
\text { - MMEF (l/s) }\end{array}$ & $\begin{array}{r}3.39 \pm 0.19 \\
93.86 \pm 3.00 \\
4.74 \pm 0.23 \\
8.06 \pm 0.54 \\
2.56 \pm 0.22\end{array}$ & $\begin{array}{c}3.89 \pm 0.06 \\
97.58 \pm 1.12 \\
5.20 \pm 0.07 \\
8.68 \pm 0.14 \\
3.31 \pm 0.10\end{array}$ & $\begin{array}{r}3.71 \pm 0.06 \\
97.04 \pm 1.44 \\
5.02 \pm 0.08 \\
8.55 \pm 0.18 \\
3.05 \pm 0.11\end{array}$ \\
\hline $\begin{array}{l}\text { Impedance } \\
\text { - R8 (hPa.s/1) } \\
-X 8(\text { ha.s } / 1) \\
- \text { FD (hPa.s/I) } \\
-\mathbb{I}_{0}(\mathrm{~Hz})\end{array}$ & $\begin{array}{r}6.65 \pm 3.92 \\
0.06 \pm 0.07 \\
-0.25 \pm 0.28 \\
8.99 \pm 0.80\end{array}$ & $\begin{array}{l}2.46 \pm 0.09 * * \\
0.18 \pm 0.03 \\
0.30 \pm 0.06 \\
7.77 \pm 0.30\end{array}$ & $\begin{array}{l}2.50 \pm 0.11 \\
0.16 \pm 0.03 \\
0.26 \pm 0.08 \\
7.90 \pm 0.36\end{array}$ \\
\hline $\begin{array}{l}\text { Cylokines } \\
- \text { TNF- } \alpha(\mathrm{ng} / \mathrm{ml}) \\
-\mathbb{I L}-8(\mathrm{ng} / \mathrm{ml}) \\
-\mathbb{I L}-4(\mathrm{pg} / \mathrm{ml}) \\
-\mathbb{I L}-5(\mathrm{pg} / \mathrm{ml}) \\
-\mathrm{IL}-6(\mathrm{pg} / \mathrm{ml}) \\
-\mathrm{IFN}-\mathrm{g}(\mathrm{pg} / \mathrm{ml})\end{array}$ & $\begin{array}{r}0.00 \pm 0.00 \\
7.81 \pm 3.28 \\
8.97 \pm 2.83 \\
7.24 \pm 2.96 \\
24.20 \pm 6.99 \\
2.22 \pm 1.03\end{array}$ & $\begin{array}{r}0.02 \pm 0.01 \\
2.29 \pm 0.46 \\
21.00 \pm 2.83 \\
10.27 \pm 1.38 \\
34.22 \pm 4.23 \\
3.36 \pm 0.49\end{array}$ & $\begin{aligned} 0.01 & \pm 0.01 \\
2.74 & \pm 0.54 * \\
21.47 & \pm 3.97 \\
8.38 & \pm 1.15 \\
35.65 & \pm 6.03 \\
3.19 & \pm 0.57\end{aligned}$ \\
\hline
\end{tabular}

Values are presented as mean $\pm S E M$.

Matched controls were selected from all other workers without bronchitis with the same age range. Differences between bronchitis os. without bronchitis or matched controls were tested by one -way ANOVA (for personal characteristics and lung function) and Mann Whitney U test (for cytokines). If significant, ${ }^{*}=p<0.05 ; * *=p<0.01$. 
None of the (serum and whole blood) cytokines was correlated with lung function parameters measured in forced expiratory maneuvers or forced oscillation technique, either in the total population study or in the specific production processes. Comparison of lung function parameters among the different production processes (Table 3.2) showed significantly lower (one-way ANOVA, $\mathrm{P}<0.01$ ) flow volume $\left(\mathrm{FEV}_{1}, \mathrm{FEV}_{1} \%, \mathrm{FVC}\right.$ and $\left.\mathrm{PEF}\right)$ and impedance $(X 8$ and $f_{0}$ ) parameters only in bulk/transport workers $(n=11)$ compared to the other groups $(n=95)$. However, flow volume and impedance parameters in those workers were still within normal range. Airway obstruction was present in 4 ( 3.8 $\%)$ subjects measured by flow volume and in $6(5.6 \%)$ subjects measured by the FOT, and was observed at all production processes, except polymers. There were no significant associations between cytokines and lung function or airway obstruction.

\section{Discussion}

In this study, blood cytokine levels and release were measured in chemical workers and related to respiratory symptoms $s_{s}$ airway obstruction, and occupational exposure. Respiratory symptoms such as bronchitis, asthma or chronic airway obstruction were distributed evenly over the production processes. Interestingly, blood IL-8 was significantly higher in workers with respiratory symptoms of (acute and chronic) bronchitis compared to workers without those symptoms. This finding remained significant after correction for age and pack-years (logistic regression, $\mathrm{p}<0.05$ ) or number of white blood cells. A secondary analysis with a matched group verified these specific effects in this group. No evidence was found for the ' $T h_{2}$ hypothesis' (increased IL-4, IL-5; decreased IFN- $\gamma$ ) in those with asthmatic symptoms, but the number of asthmatics $(n=8)$ was probably too low. No correlation was present between specific cytokines and lung function or airway obstruction. Serum IL-4 (but not blood IL-8) was increased in workers exposed to fertilizer dust compared to the other workers, and serum IL-5 was decreased in workers exposed to various chemicals.

The finding that blood IL-8 release is significantly higher in workers with acute and chronic bronchitis is consistent with the role of this cytokine as a chemoattractant of neutrophils. IL-8 has been shown to be increased in sputum. (Richman-Eisenstat et al., 1993; Keating et al., 1996), sputum cells (Hoshi et al., 1995) and bronchial lavage fluid (Riise et al., 1995) of patients with chronic bronchitis, and also plays an important role in the development of other chronic inflammatory diseases (Donnelly et al., 1993; Broaddus et al., 1992; Lynch et al., 1992). Inflammation of the central airways is a prominent feature in subjects with chronic bronchitis. The pathology of chronic bronchitis includes an inflammatory mononuclear infiltrate in the airway wall and a neutrophil influx into the airway lumen, that produce the inflammation and induce mucus hypersecretion. There is growing evidence incriminating neutrophil and 
lymphocytes constituents in the initiation and maintenance of cough and mucus expectoration that occurs in subjects with chronic bronchitis (Hoidal, 1994). Therefore, IL -8 release may be considered as a useful marker for bronchitis.

Although the mechanism remains unclear, cigarette smaking has been associated with a significant decrease in blood cytokines, such as serum levels of IL-4, IL-5 and IFN- $\gamma$ (Kuniak et all, 1995). Our data confirms these findings for serum IL-5 and IFN-y levels. Smokers also had a significantly lower blood TNF- $\alpha$ release, associated with a more frequent detectable TNF- $\alpha$ in past and nonsmokers. In addition, both whole blood and serum cytokines levels (except blood $\mathrm{IL}-8$ ) in smokers were negatively associated to pack-years (data not shown), although few actually reached statistically significance. We showed that both whole blood release and serum cytokine levels were inversely related to age and years of employment, although only serum IL-5 and IL-6 levels reached a negative significant correlation $(p<0.05)$ with age. We hypothesize that this may be a nonspecific phenomenon, related to decreasing ability and capacity in relation to aging process of white blood cells to produce cytokines in response to chemical stimulation.

Overall, the effects of occupational exposure at these levels are smaller than those observed by smoking. Apart from workers exposed to fertilizer dust (increased serum IL-4) and those in various chemicals (decreased serum IL-5), no association between chemical exposure and cytokines or respiratory symptoms was observed. No effects were noted in the subjects that are exposed to isocyanates or polymeric dusts, known to be potent respiratory sensitizers (Kimber and Dearman, 1994). Bulk/transport workers are exposed to high $<25$ $\mathrm{mg} / \mathrm{m}^{3}$ ) concentrations of dusts containing nitrogen, phosphate and potassium salts; although these dusts are generally described as 'inert', it is well known that continuous exposure to high-levels can lead to respiratory symptoms and accelarated lung function decline (Becklake, 1989). The latter is confirmed by lung function measurements in this group (Table 3.2) and the increased serum IL-4 is suggested to be associated (Kelley, 1993) to mild chronic airway inflammation, also involved in airway obstruction. It is impossible to relate any agents possibly involved (Table 3.1) to the decrease in serum IL-5 in chemical workers; any clue might generated from compounds that are specifically toxic to T-cells or suppress its production of $\mathbb{I L}-5$. Whether this decrease is associated with ameliorated IgE and IgA levels or eosinophils was not determined.

In summary, whole blood cytokine production and serum blood cytokine levels appear to be associated with age, smoking and respiratory symptoms. The data support further use of IL-8 as a marker of chronic bronchitis in the absence of lung function changes, but can not rule out the involvement of other cytokines. The (low) levels and complexity of the exposure in this study do not allow us to specify a relationship between respiratory effects, cytokines and specific occupational agents. 


\section{Acknowledgements}

The authors are sincerely indebted to all workers for their participation in this study and to G. Sambaer for his assistance in flow volume measurements and data retrieval. The authors also thank other wurses of the medical service for their assistance and hemocytometry measurements. Prof. Jos Kleinjans, Ph.D. is acknowledged for critically reviewing the wanuscript.

\section{References}

Balmes JR, Chen LL, Scannell C, Tager I, Christian D, Hearne PQ, Kelly T, Aris RM (1996) Ozone-induced decrements in FEV, and FVC do not correlate with measures of inflammation. Am J Respir Crit Care Med 153:904-909.

Becklake MR (1989) Occupational exposures: evidence for a causal association with chronic obstructive pulmonary disease. Am Rev Respir Dis 140:585-591.

Borm PJA, Schins RPF, Derhaag. TJM, Kant IJ (1996) Cross-shift changes in blood inflammatory markers occur in the absence of airway obstruction in workers exposed to grain dust. Chest 109:1078-1083.

Broaddus VC, Hebert CA, Vitangcol RV, Hoeffel JM, Bernstein MS, Boyland AM (1992) Interleukin-8 is a major neutrophilic chemotactic factor in pleural fluid of patients with empyema. Am Rev Respir Dis 146:825-830.

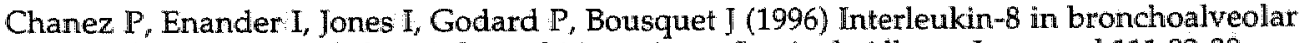
lavage of asthmatic and chronic bronchitis patients. Int Arch Allergy Immunol 111:83-88.

Collart MA, Belin D, Vassali I, DeKossodo S, Vassali D (1986) IFN- $\gamma$ enhances macrophage transcription of the TNF, IL-1 and urokinase genes, which are controlled by short-lived repressors. J. Exp Med 164:2113-2124.

Donnelly SC, Strieter RM, Kunkel SL, Walz A, Robertson CR, Carter DC, Grant IS, Pollok AJ. Haslett C (1993) Interleukin-8 and the development of adult respiratory distress syndrome in at risk patient group. Lancet $341: 643-647$.

Elias JA, Freundlich B, Kern JA, Rosenbloom J (1990) Cytokine networks in the regulation of inflammation and fibrosis in the lung. Chest $97: 1439-1445$.

Hoidal JR (1994) Pathogenesis of chronic bronchitis. Semin Respir Infect 9:8-12.

Holtzman MJ. Sampath D, Castro M, Look DC, Jayaraman S (1996) Perspective, The Onetwo of $T$ helper cells: Does interferon- $\gamma$ knock out the $T h_{2}$ hypothesis for asthma? Am I Respir Cell Mol Biol 14:316-318.

Hoshi $\mathrm{H}$, Ohno I, Honma M, Tanno $Y$, Yamauchi $K$, Tamura G, Shirato K (1995) IL-5, IL-8 and GM-CSF immunostaining of sputum cells in bronchial asthma and chronic bronchitis. Clin Exp Allergy 25:720-728. 
Jorna THJM, Schins RPF, Lenaerts L, Derhaag TJM, Wouters EFM, Borm PJA (1994) Airflow obstruction and Monocyte TNF- $\alpha$ release in coal workers. Exp Lung Res 20:421431.

Keating VM, Collins PD, Scott DM, Barnes PJ (1996) Differences in Interleukin-8 and Tumor Necrosis Factor-alpha in induced sputum from patients with chronic obstructive pulmonary disease or asthma. Am J Respir Crit Care Med 153:530-534.

Kelley J (1993) Cytokines of the lung. New York, Marcel Dekker.

Keman $S$, Willemse $B$, Wesseling GJ, Kusters E, Borm PJA (1996) A five year follow-up of lung function among chemical workers using flow-volume and impedance measurements. Eur Respir J 9:2109-2115.

Kemain S, Schins RPF, Lenaerts L, Borm PIA (1995) 10-year longitudinal changes in FEV 1 of coal miners are related to later progression of CWP and TNF- $\alpha$ production by blood monocytes. Am J Res Crit Care Med 151:A710.

Kennedy SM (1992) State of the art reviews: acquired airway hyperresponsiveness from non-immunogenic irritant exposure. Occup Med 7:287-300.

Kimber I and Dearman RJ (1994) Immune response to contact and respiratory allergens. In: Dean $J H_{\text {, }}$ Luster $I M$, Munson $A E$, and Kimber 1 (Eds). Immunotoxicology and immunopharmacology. New York, Raven Press, pp. 663-679.

Kuniak MP, Tsunoda M, Weiss ST, Satoh T, Guevarra L, Tollerud DJ (1995) Cigarette smoking and serum cytokine levels. Am J Respir Crit Care Med 151:A565.

Làndserr FJ, Nagels J, Demedts M, Billiet L, Van de Woestijne KP (1976) A new method to determine frequency characteristics of the respiratory system. J Appl Physiol 41:101-106.

Leeuwenberg JFM, Dentener MA, Buurman WA (1994) Lipopolysaccharide LPS-mediated soluble TNF receptor release and TNF receptor expression by monocytes. Role of CD14, LPS binding protein, and bactericidal permeability increasing protein. I Immunol 152:50705076.

Lynch JP, Standiford TJ, Rolfe MW, Kunkel SL, Strieter RM (1992) Neutrophilic alveolitis in idiopathic pulmonary fibrosis. Am Rev respir Dis 145:1433-1439.

Noah TL, Henderson FW, Henry MM, Peden DB, Devlin DB (1995-a) Nasal lavage cytokines in normal, allergic, and asthmatic school-age children. Am J Resp Crit care Med 152:1290-1296.

Noah TL, Henderson FW, Wortman IA, Devlin RB, Handy I, Koren HS, Becker S (1995-b) Nasal cytokine production in viral acute upper respiratory infection of childhood. I Infect Dis 171:584-592.

Orehek I. Nicoli MM, Delpierre $S$, Beaupré A (1981) Influence of the previous deep inspiration on the spirometric measurement of provoked broncho-constriction in asthma. Am Rev Respir Dis 123:269-272. 
Quamjer PhH (1983) Standardized lung function testing. Bull Eur Physio-path Respir 19 (Suppl. 5):1-95.

Richman-Eisenstat JB, Jorens PG, Hebert CA, Ueki I, Nadel JA (1993) Interleukin-8: an important chemoattractant in sputum of patients with chronic inflammatory airway diseases. Am J Physiol 246:413-418.

Riise GC, Ahlstedt S, Larsson S, Enader I, Jones I, Larsson P, Andersson B (1995) Bronchilal inflammation in chronic bronchitis assessed by measurement of cell products in bronchial lavage fluid. Thorax 50:360-365.

Schins RPF and Borm PJA (1995) Epidemiological evaluation of release of monocyte TNF- $\alpha$ as an exposure and effect marker in pneumoconiosis: a five year follow-up study of coal workers. Occup Environ Med 52:441-450.

Schins RPF, van Hartingsveldt B, Borm PJA (1996) Ex-vivo cytokine release from whole blood. A routine method for health effect screening. Exp Toxicol Pathol 48:494-496..

Strieter RM, Standiford TJ, Rolfe MW, Kunkel SL (1993) Interleukin-8. In: Kelley J (ed), Cytokines of the lung. New York, Marcel Dekker, pp.281-298.

Tollerud DJ, Sparrow D, Weiss S, Guevarra L (1994) Chemiluminescence assay for human cytokines. J Cell Bioch 18 (Suppl.):A-26.

Zitmick RJ and Elias JA (1993): Interleukin-6 and the lung. In:Kelley J, Ed. Cytokines of the lung. New York, Marcel Dekker, pp. 229-280. 


\title{
Chapter 4
}

\section{BLOOD CYTOKINES IN COAL DUST INDUCED RESPIRATORY DISORDERS}

\author{
Soedjajadi Keman, Roel P.F. Schins, and Paul J.A. Borm. \\ Department of Health Risk Analysis and Toxicology, Maastricht University, \\ PO Box 616, 6200-MD Maastricht, The Netherlands.
}

\begin{abstract}
Cytokines play an important role in pulmonary inflammatory responses to various exposures, such as coal dust. Previously, we demonstrated that Tumor Necrosis Factoralpha (TNF-a) is associated to progression of pneumoconiosis in retired coal worker. The purpose of this study was to investigate the relation between other cytokines and respiratory impairment in coal workers. A number of other cytokines known to be involved in coal dust induced responses, were studied in serum and monocyte supernatants of 104 retired coal workers. Short-lived cytokines Transforming Growth Factor-beta (TGF- $\beta$ ) and interleukin-6 (IL-6) were measured in monocyte incubations, whereas interleukin-8 (IL-8), soluble TNF receptor-55 (sTNF-R55) and soluble TNF receptor-75 (sTNF-R75) were determined in serum. Spontaneous IL-6 release from monocytes was significantly lower in coal workers with bronchitis and those with airway obstruction. Higher serum IL-8 levels were associated with better lung function (flow volume and impedance). Inverse correlation between impedance values and STNF-R55 were observed, although medication was found to be a confounder.

Our data suggest that TNF- $\alpha$ and IL- 8 are related to respiratory impairment in workers exposed to coal dust. These finding further support the role of these cytokines in the pathogenesis of respiratory impairment such as chronic bronchitis and airway obstruction.
\end{abstract}

\section{Introduction}

Coal dust exposure is associated with a high prevalence of respiratory and interstitial disorders, such as Coal Workers Pneumoconiosis (CWP) and chronic obstructive pulmonary disease (COPD), (Wouters et al., 1994). Cytokines play an important role in the pulmonary inflammatory response to coal dust (Vanhée et al., 1994). Alterations in cytokine production and secretion represent determining forces in inflammatory and fibrotic lung disorders (Kelley, 1990; Howarth et al., 1994). Moreover, it is now appreciated that cytokines exhibit both pleotrophy and multiplicity of actions and that differing cytokines may interact both synergistically and antagonistically (Elias et al., 1990; Howarth et al., 1994). Previously, we demonstrated that monocyte Tumor Necrosis Factor-alpha (TNFa) release might be a marker of individual susceptibility to progression of CWP (Schins and Borm, 1995-a) which was also related to airway obstruction in coal miners (Jorna et al., 1994). TNF- $\alpha$ is a multi functional proinflammatory cytokine, that acts together with interleukin-1 (IL-1) and interleukin-8 (IL-8) to 
orchestrate local inflammation in the lung. IL-8 and TNF- $\alpha$ have been shown to be increased in the airways of patients with asthma, chronic bronchitis and COPD (Siracusa et al., 1992; Riise et al., 1995; Nocker et al., 1996; Keating et al., 1996). It is suggested that the systemic effects of TNF- $\alpha$ are regulated by the extracellular part of two TNF-receptors (R55 and R75), shedded from many different cell types and tissues (Shepperd, 1991; Brockhous et al., 1990). Moreover, other longer lived cytokines are induced autocrine and paracrine by TNF- $\alpha$, including Transforming Growth Factor-beta (TGF- $\beta$ ) and interleukin-6 (I1-6). TGF- $\beta$ is a potent immunosupressive molecule both for $T$ and B lymphocytes (Kehrl et al., 1986), increases transcription of fibrinocetin and procollagen genes (Ignotz et al., 1996; Fine and Goldstein 1987) and has been shown to be increased in the airways of asthmatics (Ohno et al, 1996) and in COPD. Many different blood cells such as monocytes, $T$ and B lymphocytes produce IL-6 which stimulate B-cell growth and T-cell proliferation (Gauldie et al., 1996; Zitnik and Elias, 1993). Therefore we investigated whether the above cytokines in concert with TNF- $\alpha$ are involved in the airway obstruction and lung diseases due to coal dust exposure. The serum and monocyte supernatants of 104 retired coal workers, sampled and frozen in 1992 as a part of a prospective cohort study among coal workers (Borm et al., 1988; Schins and Borm, 1994), were used for determination of these cytokines. Cytokine levels were related to respiratory symptoms and lung function after correction for smoking, age, and (cumulative) coal dust exposure.

\section{Methods}

\section{Study design and population}

This study was designed as a cross-sectional study in 1992 as part of a prospective cohort study among 156 Belgian coal workers (Schins and Borm, 1995-a). After written informed consent 104 retired coal workers were included in this study. After evaluation of a self administered Dutch version of the British Medical Research Council (BMRC) standardized questionnaire on respiratory symptorns, smoking habits and additional questions concerning working history, all subjects completed three impedance measurements and three flow volume curves. Impedance measurements were always performed before flow volume curves to avoid the influence of forced inspiratory maneuvers on bronchial tone (Orehek et al., 1981). Respiratory diseases were diagnosed based on the answers of each participant in the questionnaire. Bronchitis was diagnosed as productive cough after waking up, during smoking, and/or productive cough during winter season. Chronic bronchitis was diagnosed if the above complaints were present for at least 3 months of two sequential years. Asthma was diagnosed based on symptoms of shortmess of breath and wheezing. Chest radiographs were used by an experienced panel of three physicians to detect pneumoconiosis according to International Labour Office (ILO) criteria 1980 as described previously (Schins and Borm, 1995-a). Pack-years were calculated from the questionnaires, as average weekly of total number of packs of cigarettes smoked multiplied by the number of years smoked (Jorna et al., 1994). 


\section{Lung Function Measurements}

Impedance of the respiratory system was measured using the forced oscillation technique (FOT) described by Landsér et al. (1976). The seated subject, wearing a noseclip, supports the cheeks with his hands and breathes quietly via a tube. A pseudo-random noise pressure signal containing all harmonics of $2 \mathrm{~Hz}$ from 4 to $48 \mathrm{~Hz}$ is applied at the mouth by means of a loudspeaker. Recorded pressure and flow signals were analyzed by spectral analysis techniques. Mean values of three successive measurements, each lasting 8 seconds were used in the analysis. Of the obtained impedance data, the resistance at $8 \mathrm{~Hz}$ (R8), at $28 \mathrm{~Hz}$ (R28), the difference between R28 and R8 (frequency dependence (FD), signifying the course of the resistance versus frequency curve), the reactance at $8 \mathrm{~Hz}(\times 8)$ and the resonant frequency $\left(f_{0}\right)$ were used for analysis. R8 was chosen because at this frequency usually coherence function $>0.95$ was obtained, which was not always obtained at lower frequencies. $\mathrm{A}$ negative $\mathrm{FD}$ and a resonance frequency $\left(f_{0}\right)$ exceeding $15 \mathrm{~Hz}$ were regarded as indicative for airflow limitation. The equipment was calibrated twice daily and all measurements were performed using the same apparatus by the same investigator. Forced expiratory flow volume curves were recorded according to European Community of Coal and Steel (ECCS) criteria using a Vitalograph P5 dry spirometer. Three recordings of forced vital capacity within $5 \%$ or a $100 \mathrm{ml}$ range were obtained from each subject. Parameters derived from the flow volume curves were: forced vital capacity (FVC); forced expiratory volume in 1 second $\left(\mathrm{FEV}_{1}\right) ; \mathrm{FEV}_{1} / \mathrm{FVC}$ ratio, peak expiratory flow volume (PEF); and maximal mid expiratory flow volume (MMEF). All flow volume values were related to the reference values of the ECCS (Quanjer, 1983) for individual diagnosis. Values two or more standard deviations below the reference value (i.e. a value less than $80 \%$ of the standard value) of $\mathrm{FEV}_{1}$ reflected airway obstruction. The spirometer was calibrated two times daily and all subjects were measured on the same spirometer by the same investigator.

\section{Exposure analysis}

Worklife cumulative dust exposure was obtained in 1992 as previously described (Schins and Borm, 1995-a). The cumulative dust exposure at the coalface was calculated by multiplying the sum of the yearly mean dust concentration for the colliery where the workers worked by the average time worked underground during one year. The resulting individual units are expressed as gram-hours per cubic meter of sampled air $\left(\mathrm{gh} / \mathrm{m}^{3}\right)$ and converted into 'respirable dust' concentration using the formula: respirable dust concentration $=1.1$ (total dust concentration) $)^{1 / 2}$. Time underground was estimated at 1000 hours per year: 6 hours/shift (allowance for traveling time) $X$ 220 shifts/year $X 75 \%$ ( $25 \%$ taken as absenteeism rate).

\section{Blood cytokine analysis}

Blood sample $(40 \mathrm{ml})$ was taken from each coal worker; a $10 \mathrm{ml}$ portion was processed immediately by centrifugation ( $3000 \mathrm{rpm}, 10 \mathrm{~min}$ ) and plasma and red blood cell pallet were storaged. The rest $(30 \mathrm{ml})$ was storaged overnight at room temperature, and blood monocytes were isolated the next day by density 
centrifugation and adherence (Schins and Borm, 1995-a). Monocytes were incubated for $18 \mathrm{hrs}$ with various stimulation including lipopolysaccharide (LPS; $3 \mathrm{ng} / \mathrm{ml}$ and $1000 \mathrm{ng} / \mathrm{ml}$; TNF- $\alpha$ only), coal dust $(5 \mathrm{mg} / \mathrm{ml})$ and silica $(0.5 \mathrm{mg} / \mathrm{ml})$. TNF- $\alpha$, TGF- $\beta 2$, and $I L-6$ in monocyte sups and serum levels of IL-8, sTNF-R55 and STNF-R75 were determined by specific ELISAs as described previously (Leeuwenberg et al., 1994; Schins and Borm, 1995-b; Borm et al., 1996; Schins et al., 1996). Detection limits were: $10 \mathrm{pg} / \mathrm{ml}$ for TNF- $\alpha, 20 \mathrm{pg} / \mathrm{ml}$ for TGF- $\beta, 100 \mathrm{pg} / \mathrm{mL}$ for $\mathrm{IL}-6,30 \mathrm{pg} / \mathrm{ml}$ for sTNF-R55 and sTNF-R75, and $10 \mathrm{pg} / \mathrm{ml}$ for IL-8.

\section{Statistical Analysis}

Statistical analyses were done using both parametric and non-parametric statistics. Correlations between personal characteristics, lung function parameters, and cytokines were tested by Pearson (normally distributed data) and Spearman's rank (not normally distributed data) correlation test. Average (monocyte sups and serum) cytokine levels among groups of smoking habits (current, past, never) were tested for significance using one-way analysis of variance (ANOVA) or Kruskal Wallis. Comparison between groups with and without airway obstruction or respiratory complaints were tested by ANOVA or Mann Whitney $U$ - test. Confounding factors such as age and pack-years which influenced relationship between cytokines and respiratory symptoms, and lung function were controlled using the logistic regression. Probability values $<0.05$ were considered as statistically significant. All procedures were done using SPSS for Windows 6.0 software.

\section{Results}

\section{General data}

General characteristics are shown in Table 4.1. Eleven participants $(10.6 \%)$ had airway obstruction measured by flow volume criteria ( $\mathrm{FEV}_{1}<80 \%$ predicted), while 9 subjects $(8.7 \%)$ had airway obstruction measured by the forced oscillation technique (negative FD and $\mathrm{f}_{0}>15 \mathrm{~Hz}$ ). Upper and lower tertile cut off points of $\mathrm{FEV}_{1}$ were $3.8 \mathrm{~L}$ and $3.3 \mathrm{~L}$ respectively. Miners with ILO classification for CWP 1/0 had lower $\mathrm{FEV}_{1}$ and $\mathrm{FVC}$ values compared to miners with ILO classification $0 / 0$. However FEV $\%$ was not different between both groups. Coal dust induced TGF $\beta$ release and sTNF-R55 concentration were significantly correlated to age $(\mathrm{r}=-0.24, \mathrm{p}=0.03$ and $\mathrm{r}=-0.28, \mathrm{p}<0.01$, respectively $)$. Coal dust induced TNF- $\alpha$ release was significantly correlated to pack-years (Spearman, $\mathrm{r}=-0.28, \mathrm{p}<0.01$ ). No other significant correlations were found between cytokines and smoking habits (current, past and nonsmokers), cumulative coal dust exposure or total years worked underground.

\section{Cytokine and lung function}

Serum levels of sTNF-R55 showed a significant correlation only with impedance parameters, including $R 8(r=0.22, p=0.03), X 8(r=-0.24, p=0.01)$, and $f_{0}$ $(r=0.19, p<0.01)$. Better impedance values (low $R 8$ and $f_{0} ;$ high $\left.X 8\right)$ were associate 
Table 4.1. General characteristics of cohort in 1992

\begin{tabular}{|c|c|c|c|}
\hline Parameter & $n$ & Mean $\pm S D$ & Range \\
\hline $\begin{array}{l}\text { Persondl Characteristics } \\
\text { - Age (yrs) } \\
\text { - Underground (yrs) } \\
\text { - Cumulative dust (gh/m } 3 \text { ) } \\
\text { - Smoking habits } \\
\text { : Current/Ex-/Non-smokers } \\
\text { : Packyears } \\
\text { - CWP classification } \\
\text { Yes / No } \\
0 / 0 ; 0 / 1 \\
1 / 0 ; 1 / 1 ; 1 / 2 \\
2 / 1 ; 2 / 2 ; 2 / 3 \\
3 / 2 ; 3 / 3 ; 3 /+ \\
\text { - Respiratory symptoms } \\
\text { Cough (yes / no) } \\
\text { Phlegm (yes/no) } \\
\text { Shortmess of Breath (yes } / \text { no) } \\
\text { Wheezing (yes } / \text { no) } \\
\end{array}$ & $\begin{array}{l}104 \\
103 \\
103 \\
103 \\
103 \\
103\end{array}$ & $\begin{array}{r}48.38 \pm 0.51 \\
22.95 \pm 0.41 \\
101.26 \pm 5.68 \\
38 / 49 / 16 \\
123.72 \pm 11.13 \\
28 / 75 \\
75 ; 7 \\
1 ; 2 ; 2 \\
2 ; 4 ; 1 \\
3 ; 3 ; 3 \\
32 / 71 \\
35 / 68 \\
62 / 41 \\
49 / 54 \\
\end{array}$ & $\begin{array}{r}37-60 \\
15-35 \\
10-280\end{array}$ \\
\hline $\begin{array}{l}\text { Lung Function } \\
-\mathrm{FEV}_{1}(\mathrm{l}) \\
-\mathrm{FEV}_{1} \% \\
-\mathrm{FVC}(\mathrm{I}) \\
-\mathrm{PEF}(\mathrm{l} / \mathrm{s}) \\
-\mathrm{MMEF}(\mathrm{l} / \mathrm{s}) \\
-\mathrm{R} 8(\mathrm{hPa} / \mathrm{s} / \mathrm{l}) \\
-\mathrm{X8}(\mathrm{hPa} . \mathrm{s} / \mathrm{l}) \\
-\mathrm{FD}(\mathrm{hPa} / \mathrm{s} / \mathrm{l}) \\
-\mathrm{f}_{0}(\mathrm{~Hz}) \\
\end{array}$ & $\begin{array}{l}104 \\
104 \\
104 \\
104 \\
104 \\
104 \\
104 \\
104 \\
104 \\
\end{array}$ & $\begin{array}{r}3.58 \pm 0.08 \\
103.63 \pm 1.68 \\
4.67 \pm 0.08 \\
9.78 \pm 0.19 \\
2.95 \pm 0.12 \\
2.65 \pm 0.10 \\
-0.15 \pm 0.05 \\
-0.15 \pm 0.05 \\
10.52 \pm 0.39 \\
\end{array}$ & $\begin{array}{c}1.60-5.89 \\
56-144 \\
2.87-7.10 \\
5.80-14.80 \\
0.3-6.5 \\
1.30-6.12 \\
-3.15-0.58 \\
-2.25-0.89 \\
4.94-28.88 \\
\end{array}$ \\
\hline $\begin{array}{l}\text { Cytokine levels } \\
\text { - Serum IL-8 (pg/mi) } \\
\text { - Soluble TNF-R55 (ng/ml) } \\
\text { - Soluble TNF-R75 (ng/ml) } \\
\text { - Blood Monocyte IL-6 (ng/ml) } \\
\text { Spontaneous } \\
\text { Coal Dust induced } \\
\text { Silica induced } \\
\text { - Blood Monocyte TGF- } \beta \text { (pg/ml) } \\
\text { Spontaneous total } \\
\text { Spontaneous active } \\
\text { Coal dust induced total } \\
\text { Coal dust induced active } \\
\text { Sillica induced total } \\
\text { Silica induced active } \\
\text { - Blood Monocyte TNF- } \alpha \text { (ng/ml) } \\
\text { Spontaneous } \\
\text { Coal dust induced } \\
\text { Silica induced }\end{array}$ & $\begin{array}{c}95 \\
103 \\
103 \\
\\
73 \\
78 \\
62 \\
\\
92 \\
92 \\
81 \\
81 \\
85 \\
85\end{array}$ & $\begin{aligned} & 5.13 \pm 1.52 \\
& 1.42 \pm 0.04 \\
& 1.99 \pm 0.05 \\
& \\
& 5.56 \pm 0.65 \\
& 10.98 \pm 2.18 \\
& 3.32 \pm 0.42 \\
& \\
& 1324.70 \pm 116.70 \\
& 176.11 \pm 19.25 \\
& 1481.78 \pm 136.15 \\
& 107.25 \pm 12.78 \\
& 1423.95 \pm 87.13 \\
& 157.88 \pm 16.96 \\
& \\
& 0.17 \pm 0.02 \\
& 1.92 \pm 0.14 \\
& 0.77 \pm 0.09 \\
&\end{aligned}$ & $\begin{array}{c}0.00-79.00 \\
0.36-3.08 \\
1.05-3.68 \\
0.27-32.90 \\
1.24-153.58 \\
0.14-23.05 \\
\\
588.00-6000.00 \\
10.00-1064.00 \\
20.00-5240.00 \\
10.00-804.00 \\
264.00-3860.00 \\
10.00-1012.00\end{array}$ \\
\hline
\end{tabular}


to lower STNF-R55 values. However, after exclusion of workers with medication, previously shown to affect sTNF-R55 in this group (Schins and Borm, 1995-b), all significances were lost, except for $X 8$. Serum IL-8 levels were detectable $(>10$ $\mathrm{pg} / \mathrm{ml}$ ) in 15 out of 95 samples. As illustrated in Figure 4.1, the proportion of miners with detectable IL-8 levels was significantly higher in those belonging in the upper FEV 1 tertile (9 out of 31) versus those in the lowest tertile ( 2 out of 33 ), resulting in a significant odds ratio of 6.8 with a $95 \%$ confidence interval from 1.3 to 34.3 . In the middle tertile $14 \%$ had detectable serum $11-8$ (Figure 4.1 ).

Figure 4.1.

Proportion of detectable serum IL- 8 in tertile of $\mathrm{FEV}_{1}, \mathrm{R}_{n}$, and FD
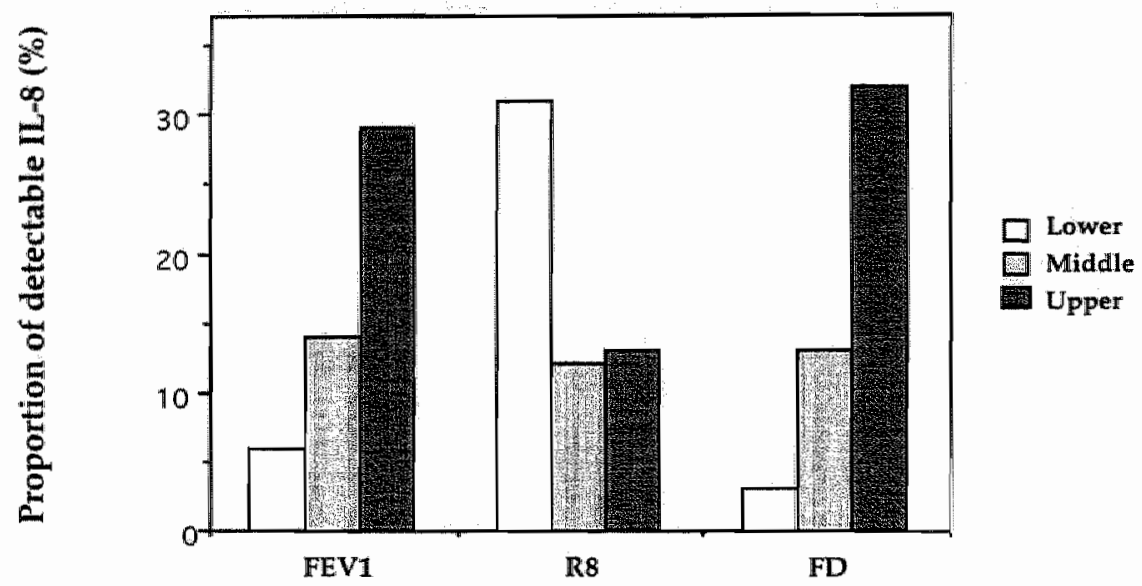

\section{Tertile of Lung Function}

Relation between serum IL-8 levels and lung function parameters as determined by flow volume $\left(E_{E V} V_{1}\right.$ ) or impedance (R8, FD) measurements. The figure shows the percentage of subjects with detectable serumt IL-8 according their classification into tertiles based on upper and lower cut off points of FEV ${ }_{1}, R 8$ and FD values. Spearman's rank correlation analysis showed a trend of increased number of individuals with detectable $I L-8$ with better lung function parameters, i.e. a higher $F E V_{1}$ or lower R8 ar a higher FD.

A similar trend was seen when subjects were classified into tertiles using impedance parameters R8 and FD (Fig. 4.1). An inverse analysis showed that subjects with detectable IL-8 had a significantly higher $\mathrm{FEV}_{1} \%$, and also better impedance values (R8 and FD) compared to subjects with non detectable IL-8 (Table 4.2). Serum IL-8 concentrations were not related to age, smoking or exposure. A multiple regression using pack-years, age and serum IL-8 as independent parameters led to a significant fit of $\mathrm{FEV}_{1} \%$ and $\mathrm{FD}$ in the subjects 
with detectable IL- $8(n=15, p<0.05)$. Among the monocyte cytokines, IL- 6 and TNF- $\alpha$ showed relations to respiratory impairment. As previously reported, silica. induced TNF- $\alpha$ release was significantly increased in coal workers with airway obstruction measured using flow volume as well as impedance parameters (Jorna et al., 1994). Furthermore, unstimulated release of IL-6 was lower in airway obstruction as defined by impedance $(n=7,2.94 \pm 2.80$ vs. $n=66,5.94 \pm 5.77 ; p<0.05)$, phlegm $(n=29,3.99 \pm 2.88$ vs. $n=43,6.67 \pm 6.72 ; p<0.05)$, and bronchitis $(n=23$, $3.49 \pm 3.31$ vs. $n=49,6.58 \pm 6.43 ; \mathrm{p}<0.05$ ) compared to appropriate controls.

Table 4.2. Lung function and exposure values in retired coal workers with and without detectable serum $\Pi \mathrm{L}-8$

\begin{tabular}{|c|c|c|c|}
\hline Parameter & $\begin{array}{c}\text { Not detectable } \\
\text { serim IL-8 } \\
n=80\end{array}$ & $\begin{array}{c}\text { Detectable } \\
\text { serum } I L-8 \\
\quad n=15\end{array}$ & p value \\
\hline $\begin{array}{l}\text { Flow Volume } \\
- \text { FEV }_{1}(1) \\
\text { - FEV } 1 \%(\%) \\
\text { - FVC }(1) \\
\text { - PEF }(1 / \mathrm{s}) \\
\text { - MMEF }(1 / \mathrm{s})\end{array}$ & $\begin{array}{c}3.49 \pm 0.75 \\
101.45 \pm 16.72 \\
4.59 \pm 0.85 \\
10.45 \pm 7.09 \\
2.83 \pm 1.16\end{array}$ & $\begin{array}{c}3.89 \pm 0.62 \\
113.80 \pm 17.43 \\
5.03 \pm 0.66 \\
10.45 \pm 2.06 \\
3.33 \pm 1.28\end{array}$ & $\begin{array}{l}0.06 \\
0.01 \\
0.06 \\
0.99 \\
0.13\end{array}$ \\
\hline $\begin{array}{l}\text { Impedance } \\
- \text { R8 (hpa.s/1) } \\
- \text { X8 (hpa.s/1) } \\
- \text { FD (hpa.s/1) } \\
-f_{0}(\mathrm{~Hz})\end{array}$ & $\begin{array}{r}2.76 \pm 1.05 \\
-0.19 \pm 0.55 \\
-0.22 \pm 0.56 \\
10.96 \pm 4.23\end{array}$ & $\begin{array}{l}1.94 \pm 0.48 \\
0.06 \pm 0.23 \\
0.20 \pm 0.26 \\
8.79 \pm 1.60\end{array}$ & $\begin{array}{l}<0.01 \\
0.09 \\
<0.01 \\
0.07\end{array}$ \\
\hline $\begin{array}{l}\text { Exposure } \\
\text { - Pack-years } \\
\text { - Total underground (yrs) } \\
\text { - Cum dust exposure }\left(\mathrm{gh} / \mathrm{m}^{3}\right) \\
\text { - Quartz exposure }\left(\mathrm{gh} / \mathrm{m}^{3}\right)\end{array}$ & $\begin{array}{c}117.94 \pm 118.64 \\
23.00 \pm 4.07 \\
100.31 \pm 60.27 \\
5.285 .31 \pm 2884.68\end{array}$ & $\begin{aligned} 160.07 & \pm 96.46 \\
24.27 & \pm 4.08 \\
120.00 & \pm 48.54 \\
6,143.33 & \pm 2,412.16\end{aligned}$ & $\begin{array}{l}0.20 \\
0.27 \\
0.24 \\
0.28\end{array}$ \\
\hline $\begin{array}{l}\text { Classical factors } \\
\text { - Age (yrs) } \\
\text { - Height (cm) } \\
\text { - Weight (kg) }\end{array}$ & $\begin{array}{r}48.31 \pm 5.22 \\
170.09 \pm 6.21 \\
77.69 \pm 9.70\end{array}$ & $\begin{array}{c}48.87 \pm 4.16 \\
171.07 \pm 6.85 \\
74.20 \pm 12.28\end{array}$ & $\begin{array}{l}0.70 \\
0.58 \\
0.22\end{array}$ \\
\hline
\end{tabular}

Values are presented as mean $\pm S E M$.

Significant differences were tested by ane-way ANOVA. 


\section{Discussion}

Since coal dust exposure leads to serious respiratory impairment, and cytokines play an important role especially in pulmonary inflammatory response, we evaluated cytokines as markers of respiratory symptoms, lung function, and airway obstruction. In serum, we determined concentration of the proinflammatory cytokine IL-8 and of the soluble shedding products of the $55 \mathrm{kD}$ and $75 \mathrm{kD}$ TNF receptors. Peripheral blood monocytes were isolated to determine ex-vivo the spontaneous as well as the mineral particle stimulated release of TNF $-\alpha$, IL- 6 and TGF- $\beta$. As previously reported, silica stimulated release of TNF- $\alpha$ was increased in miners with obstruction, irrespective of the presence of pneumoconiosis (Jorna et al., 1994). Recently, other investigators found that LPS stimulated monocytes of COPD patients produce higher TNF- $\alpha$ than controls (de Godoy et al., 1996). Based on these observations, one could suggest that TNF- $\alpha$ may be involved in obstructive lung disease. In line with this, STNF-R55 concentrations in serum were correlated to lung function as determined by impedance. However, the lower R-55 levels in those with better impedance values might in part be explained by the use of medication, previously shown to affect serum sTNF-R55 concentrations (Schins and Borm, 1995-b). Nevertheless, upon correlation for medication, $X 8$ was still correlated to sTNF-R55. However, sTNF-R75 concentrations in serum were not related to any measure of lung function, although they are increased in pneumoconiosis (Schins and Borm, $1995-b)$. Further support for the role of TNF- $\alpha$ in respiratory impairments is provided by analysis of TNF- $\alpha$ in relation to longitudinal lung function decline as calculated by linear regression over a ten-year interval prior to examination in this group (Keman et al., 1995). Remarkably, TNF- $\alpha$ released from monocytes stimulated with coal dust was also significantly higher in miners with rapid decline of $\mathrm{FEV}_{1}\left(2.55 \pm 0.43 \mathrm{ng} / \mathrm{ml}\right.$ with a $\mathrm{FEV}_{1}$ of $-68.4 \mathrm{ml} /$ year $)$ versus miners with a slow decline $\left(1.49 \pm 0.17 \mathrm{ng} / \mathrm{ml}\right.$ with a $\mathrm{FEV}_{1}$ of $-10.4 \mathrm{ml} /$ year $)$. This relation was not biased by cumulative dust exposure, smoking, or classical parameters as age, height, body weight, and remained present if subjects with obstruction ( $\mathrm{FEV}_{1}$ $<80 \%$ ) were excluded.

In addition to the above findings, we showed that both monocyte release of IL-6 and serum level of IL-8 are higher in miners with better lung function. We showed that unstimulated IL-6 release from monocytes is significantly lower in miners with bronchitis as well as in those with airway obstruction compared to the appropriate references. As far as we know, no reports on the role of IL-6 in chronic bronchitis are available and the involvement of IL-6 in respiratory impairment has merely restricted to asthma or pneumoconiosis (Chanez et all, 1994; Homolka et al., 1993; Vanhee et al., 1995). Chanez and coworkers found that LPS induced IL-6 release from blood monocytes or alveolar macrophages is reduced in asthma (Chanez et al., 1994), while other investigators found that spontaneous IL-6 release from macrophages, but not from monocytes, of asthmatic was increased compared to cells from controls (Gosset et al., 1992). The reduced level of IL-6 observed in obstructive individuals in our study is however unlikely caused by increased IL-4 in asthma as suggested by Chanez et al. (1994). Furthermore, the lack of correlations in our study does not support an involvement of these factors in monocyte IL-6 release. 
Interestingly, using three independent lung function parameters, we found that higher (detectable) serum IL-8 levels were associated with better lung function. This seems in contradiction. with other studies in which $\mathrm{KL}-8$ levels in bronchoalveolar lavage or sputum were found to be increased in chronic bronchitis or during severe airway obstruction (Richman-Eisenstat et al., 1993; Clapp et al., 1994; Riise et al., 1995; Nocker et al., 1996; Keatings et al., 1996). However, recently we have also determined blood IL-8 levels in 102 chemical workers and found that concentrations were increased in subjects with chronic bronchitis (Keman et al., 1996). In that study as well as in the present study, none of the individuals suffered from severe airway limitation in contrast to the studies performed by other investigators. Moreover, the proportion of subjects with detectable IL- 8 in the coal miners and a age matched non-exposed reference group from which blood was collected and stored at the same time point were comparable. Unfortunately, no lung function data of these non-exposed references are available to confirm the positive correlation between serum IL- 8 and lung function in the absence of chronic coal dust exposure. We suggest that in mild respiratory impairments other than chronic bronchitis, other cytokines or mediators than IL-8 might be predominantly involved.

Among the monocyte cytokines studied, TGF- $\beta$ was not related to respiratory impairment. Ohno and coworkers (1996) recently suggested that TGF$\beta$ may play a role in asthma. However, the enhanced TGF- $\beta$ expression in the airways of asthmatics is almost exclusively related to eosinophils, and not to macrophages as seen in pneumoconiotic disease (Vanhée et al., 1995).

In conclusion, the present study provides further support for the role of proinflammatory cytokines in lung function decline, and suggests that TNF- $\alpha$ and IL-8 are related to respiratory impairment in workers exposed to coal dust. These finding further support the role of cytokines in the pathogenesis of respiratory impairment such as chronic bronchitis and airway obstruction.

\section{Acknowledgements}

The authors thank Herwig Vinkx (GEDILO, Hasselt, Belgium) for fis assistance in file and data retrieval and seriously indebted to Bernard Preat for his work on individual exposure assessment. We thank Thim Derhagg for spirometric and Tim Jorna for impedance measurenents, and Jos Kleinjans for critically reviewing the manuscript. Wim Buuman from department of General Surgery, academic hospital of Maastricht, is acknowuledged for providing the ELISA for TNF- $\alpha$ and P. Gosset (Ist. Pasteur, Lille, France) for analysis of TGF- $\beta$. Soedjajadi Keman, MD. is a fellow from the University of Airlangga, Surabaya. Indonesia, on a grant by the Indonesian SUDR-program. This study was supported by ECSC grant $7263 / 03 / 92$ and project 229.764 of NUTRIM/Toxicology Dixision. 


\section{References}

Adler KB, Fischer BM, Wright DT, Cohn LA, Becker S (1994) Interaction between respiratory epithelial cells and cytokines: relationships to lung inflammation. Ann $N Y$ Acad Sci $725: 128-145$.

Becker S, Deylin RB, Haskill IS (1989) Differential production of TNF, macrophage colony stimulating factor, and IL-1 by human alveolar macrophages. J Leukocyte Biol 45:353-361.

Borm PJA, Palmen N, Engelen JIM, Buturman WA (1988) Spontaneous and stimulated release of Tumor Necrosis Factor $\alpha$ from blood monocytes of miners with coal workers" pneumoconiosis. Am Rev Respir Dis 138:1589-1594.

Borm PJA, Schins RPF, Derhaag TJMM, Kant IJ, Jorna THIM (1996) Cross-shift changes in blood inflammatory markers occur in the absence of airway obstruction in workers exposed to grain dust. Chest 109:1078-1085.

Brockhaus M, Schoenfeld HJ, Schlaeger EJ, Hunziker W, Lesslauer W, Loetscher H (1990) Identification of two types of tumor necrosis factor receptors on human cell lines by monodonal antibodies. Proc Natl Acad Sci 87:3127-3131.

Collart MA, Belin D, Vassalli ], Dekossodo S, Vassalli D (1986) IFN- enhances macrophage transcription of the TNF, IL-1 and urokinase genes, which are controlled by short-lived repressors J. Exp Med 164:2113-2124.

De Godoy I, Donahoe M, Calhoun WI, Mancino J, Rogers RM (1996) Elevated TNF alpha production by peripheral blood monocytes of weight-losing COPD patients. Am I Respir Crit Care Med 153:633-637.

Donnelly SC, Strieter RM, Kunkel SL, Walz A, Robertson CR, Carter DC, Grant IS, Pollock AJ. Haslett $C$ (1993) Interleukin-8 and the development of adult respiratory distress syndrome in at risk patient group. Lancet 341:643-647.

Elias JA, Freundlich B, Kern JA, Rosenbloom J (1990) Cytokine networks in the regulation of inflammation and fibrosis in the lung. Chest 97:1439-1445.

Fine A and Goldstein RH (1987) Th effect of transforming growth factor-beta on cell proliferation and collagen production by lung fibroblast. J Biol Chem 262:3897-3920.

Gosset $P$, Tsicopolous A, Wallaert B (1991) Increased secretion of Tumor Necrosis Factor $-\alpha$ and Interleukin-6 conseculive to the development of the late asthmatic reaction. J Allergy Clin Immunol 88:561-571.

Howarth PH, Bradding P, Quint D, Reddington AE, Holgate ST (1994) Cytokines and airway inflammation. Ann NY Acad Sci 725:69-82.

Ignotz RA, Endo T, Massaugue (1986) Regulation of fibronectin and type I collagen mRNA levels by transforming growth factor-beta. $\int$ Biol Chem 262:6443-64446.

International Labour Office (1980) Guidelines for the use of ILO international classification of radiographs of pneumoconiosis, Occupational Safety and Health Series No.22. Geneva, ILO.

Jorna THJM, Schins RPF, Lenaerts L, Derkaag TJMM, Wouters EFM, Borm PJA (1994) Airflow obstruction and monocyte TNF release in coal workers. Exp Lung Res 20:421-431. 
Keatings VM, Collins PD, Scott DM, Barnes PJ (1996) Differences in interleukin-8 and tumor necrosis factor-alpha in induced sputum from patients with chronic obstructive pulmonary disease or asthma. Am J Respir Cell Crit Care Med 153:530-534.

Kehrl JH, Wakefield LM, Roberts AB, Jakewlew SB, Alvarez-Mon M, Derynck R (1986) Production of transforming growth factor- $\beta$ by human $T$ lymphocytes and its potential role in the regulation of $T$ cell growth. J Exp Med 163:1037-1050.

Kelley I (1990) Cytokines of the lung. Am Rev Respir Dis 141:765-788.

Keman S, Schins RPF, Lenaerts L, Borm PJA (1995) Ten-year longitudinal changes in FEV, of coal miners are related to later progression of CWP and TNF $\alpha$ production by blood monocytes. Am J Respir Crit Care Med 151(4):A710.

Keman S, Willemse B, Schins RPF, Guevarra L, Tollerud DJ, Borm PJA (1995) Blood cytokines as markers of respiratory impairment in chemical workers. Am J Respir Crit Care Med 151(4):A794.

Kuniak MP, Tsunoda M, Weiss ST, Satoh T, Guevarra L, Tollerud DI (1995) Cigarette smoking and serum cytokine levels. Am J Respir Crit Care Med 151:A565.

Kwon OI, Au BT, Collins PD, Adcock IM, Mak JC, Robbins RR, Chung KF, Barnes PJ (1994) Tumor Necrosis Factor-induced Interleukin-8 expression in cultured human airway epithelial cells. Am J Physiol 267:398-405.

Làndsér FJ, Nagels J, Demedts, M., Billiet L, Vand De Woestijne KP (1976) A new method to determine frequency characteristics of the respiratory system. J Appl Physiol 41:101-106.

Leeuwenberg JFM, Dentener MA, Buurman WA (1994) Lipopolysaccharide LPS-mediated soluble TNF receptor release and TNF receptor expression by monacytes. Role of CD14, LPS binding protein, and bactericidal permeability increasing protein. J Immunol 152:5070-5076.

Little S, Dean T, Bevin S, Hall M, Ashton M, Church M, Warner J, Shute J (1995) Role of elevated plasma soluble ICAM-1 and bronchial lavage fluid IL-8 as markers of chronic lung disease in premature infants. Thorax 50:1073-1079.

Love RG and Miller BG (1982) Longitudinal study of lung function in coal miners. Thorax 37:93-197.

Mohr CA, Gemsa D, Graebner C, Hemenway D, Leslie KO, Absher PM, Davis GS (1991) Systemic macrophage stimulation in rats with silicosis: enhanced release of TNF- $\alpha$ from alveolar and peritoneal macrophages. Am J Respir Cell Moll Biol 5:395-402.

Nocker RE, Schoonbrood DF, Van De Graaf EA, Hack CE, Lutter R., Jansen HM, Out TA (1996) Interleukin-8 in airway inflammation in patients with asthrna and chronic obstructive pulmonary disease. Int Arch Allergy Immunol 109:183-191.

Orehek J, Nicoli MM, Delpierre S, Beaupré A (1981) Influence of the previous deep inspiration on the spirometric measurement of provoked bronchoconstriction in asthma. Am Rev Respir Dis 123: 269-272

Ohno I, Nitta $Y$, Yamauchi $K$, Hoshi $H$, Honma $H$, Woolley $K$, O'Byrne P, Tamura $G$, Jordana $M$, Shirato $K$. (1996) Transforming growth factor $\beta 1$ (TGF- $\beta 1$ 1) gene expression by eosinophils in asthmatic airway inflammation. Am J Respir Cell Mol Biol 1.5:404-409. 
Piguet PF, Collart MA, Grau GE, Sappino AP, Vassalli P (1990) Requirement of Tumor Necrosis Factor for development of silica- induced pulmonary fibrosis. Nature 344:245-247.

Quanjer PH (1983) Standardized lung function kesting. Bull Eur Physio-path Respir 19 (Suppl. 5):1-95.

Richman-Eisenstat JB, Jorens $P G$, Hebert CA, Ueki I, Nadel JA (1993) Interleukin-8: an important chemotractant in sputum of patients with chronic inflammatory airway diseases. Am J Physiol 246: L413-418.

Riise GC, Ahlstedt $S$, Larsson S, Enader I, Jones I, Larsson P, Andersson B (1995) Bronchial inflammation in chronic bronchitis assessed by measurement of cell products in bronchial lavage fluid. Thorax 50:360-365.

Schins RPF and Borm PJA (1995-a) Epidemiological evaluation of TNF- $\alpha$ as an exposure and effect marker in preumoconiosis" a five-year follow-up study among coal workers. Occup Environ Med 52:441-450.

Schins RPF and Borm PJA (1995-b) Plasma levels of soluble tumor necrosis factor receptors are increased in coal miners with pneumoconiosis. Eur Respir J 8:1658-1663.

Schins RPF, Van Hartingsveldt B, Borm PJA (1996) Ex-vivo cytokine release from whole blood: a routime method for health effect screening. Exp Toxicol Pathol 48:494-496.

Sheperd VL (1991) Cytokines receptors of the lung. Am J Respir Cell Mol Biol 5:403-410.

Siracusa A, Vechiarelli A, Brugnami G, Marabini A, Felicioni D, Serevini C (1992) Changes in interleukin-1 and tumor necrosis factor production by peripheral blood monocytes after specific bronchoprovocation test in occupational asthma. Am Rev Respir Dis 146:408-412.

Wouters EFM, Jorna THJM, Westenend M (1994) Respiratory effects of coal dust exposure : clinical effects and diagnosis. Exp Lung Res 20:385-393. 


\title{
LONGITUDINAL CHANGES IN INFLAMMATORY MARKERS IN NASAL LAVAGE OF COTTON WORKERS Relation to Endotoxin Exposure and Lung Function Changes
}

\author{
Soedjajadi Keman", Manon Jetten ${ }^{1}$, Jeroen Douwes ${ }^{2}$ and Paul J.A. Borm ${ }^{1}$. \\ ${ }^{1}$ Department of Health Risk Analysis and Toxicology, Maastricht University, \\ 2 Department of Epidemiology and Public Health Wageningen Agricultural University, \\ The Netherlands.
}

\begin{abstract}
The aim of this study was to evaluate time related changes in inflammatory markers in nasal lavage (NAL) in relation to endotoxin exposure and lung function changes. We applied nasal lavage as well as lung function and exposure measurements in a small group $(\mathrm{n}=11)$ of cotton workers during 6 weeks of observation (after 2 weeks free of exposure). Several inflammatory markers in NAL, such as interleukin-8 (IL-8), IL-6, and downstream mediators including soluble tumor necrosis factor receptor75 (sTNF-R75) and soluble intercellular adhesion molecule-1 (ICAM-1), cell counts, marker of epithelial response (uric acid) and marker of plasma exudation (albumin) were measured. At the exposure levels measured in this study [cotton dust, geometric mean $(\mathrm{GM})=1.10 \mathrm{mg} / \mathrm{m}^{3}$; endotoxin, $\mathrm{GM}=2,869 \mathrm{EU} / \mathrm{m}^{3}$, several inflammatory markers in NAL such as IL-8, sTNF-R75, and albumin tended to increase through the measurement period with increasing airborne endotoxin concentration (in six workers who had paired measurements in weeks 1 and 6). Although no statistical significance was reached, airborne endotoxin exposure and all inflammatory markers in NAL were relatively higher in cotton workers with a 6-week lung function decrease. The data suggest that inflammatory markers in NAL are associated with repeated airborne endotoxin exposure.
\end{abstract}

Accepted for publication on 10 July 1997 in:

International Archives of Occupational and Environmental Health . 
Occupational exposure to cotton dust is associated with acute and chronic inflammation of the respiratory tract, resulting in organic dust toxic syndrome, byssinosis, asthma, bronchitis and chronic airway obstruction (Merchant et al, 1973; Beck et al, 1982). Both acute and chronic respiratory effects experienced by cotton workers are dose-dependent and are thought to be triggered by microbiological contamination of the cotton fibre, with particularly bacterial endotoxins (Castellan et al., 1984; Kilburn, 1984; Rylander, 1990). At high levels of cotton dust exposture, significant cross-shift changes in lung function have been documented, that are also predictive of longterm decline in lung function (Christiani et al., 1994). At moderate levels of cotton dust exposure $\left(<1.0 \mathrm{mg} / \mathrm{m}^{3}\right)$, however, lung function changes are very slight and without any direct physiological effect (Rylander, 1990).

Although the role of endotoxin as a causative agent for (acute) lung function decreases in relation to organic dust exposure is known, it is not clear which properties are important in the production of airway inflammation and immune responses (Kunkel et al., 1994). The current understanding is that endotoxin produces its airway effects through the release of proinflammatory cytokines such as tumor necrosis factor-alpha (TNF- $\alpha$ ), interleukin-6 (IL-6), and interleukin-8 (IL-8) (Kunkel et al., 1994). In animal models, several studies have demonstrated that TNF- $\alpha$ is a crucial mediator of endotoxin-induced bronchial hyperreactivity (Kips et al., 1992), and that endotoxin responsiveness in mice is critical for the development of cotton dust-induced inflammatory responses in the airways, as assessed by bronchoalveolar lavage (BAL) (Schwartz, et al., 1994). Healthy subjects and asthmatics have shown airway inflammation as assessed by BAL after challenge with 'effective' doses lipopolysaccharide (LPS) ranging between 20 and $25 \mu \mathrm{g}$ (Sandström et al., 1992; Michell et al., 1992), or after $2-5 \mathrm{~h}$ of workplace exposure to swine dust (Larsson et all., 1994). Both protein and messenger RNA levels of the above mentioned cytokines have been increased in bronchial lavage of normal volunteers at $6 \mathrm{~h}$ after challenge with $30-60 \mu \mathrm{g}$ LPS from a grain dust extract (Clapp et al., 1994). In addition, changes in peripheral blood cytokine release have been demonstrated in relation to grain dust exposure without the presence of airway obstruction or cross-shift changes in lung function (Borm et al., 1996). Recentlly, nasal lavage (NAL) has been introduced as a method for the study of inflammatory responses in exposure to various dusts and gaseous pollutants (Devlin et al., 1991; Graham and Koren, 1990; Hauser et al., 1995; Steerenberg et al., 1996). NAL of grain workers exposed to endotoxin has shown increased total cellularity, squamous epithelial cell, and neutrophil concentrations (Blaski et al., 1996). In comparison with BAL, the technique of NAL is simple, relatively noninvasive, well tolerated, without adverse side effects (Graham and Koren, 1990; Fischer et al., 1993) and suitable for the evaluation of respiratory inflammation (Persson et al., 1992).

In this study, NAL was used as a method for the of study several biological responses to organic dust including proinflammatory cytokine release (IL-6, IL-8), several attenuating factors (sTNF-R75, sICAM-1), and markers of cell response (uric acid, albumin, total amount of cells). The objective of this study was to 
relate markers in NAL to exposure to cotton dust and endotoxin, as well as to short-term changes in lung function. To achieve these objectives, a 6-week shortterm longitudinal study was done in a total of 11 workers exposed to endotoxincontaining cotton dust after a 2-week exposure-free period.

\section{Methods}

\section{Study Design}

A total of 11 workers exposed to cotton dust in a textile factory were included in a 6 week short-term longitudinal study after a 2 week exposure-free period (see diagram of the study design). Written informed consent was obtained from each worker after evaluation of a validated questionnaire on respiratory symptoms, smoking, and working history. Lung function was measured using flow volume curves daily in the afternoon (between 1.00 and $3.00 \mathrm{pm}$ ) during weeks 1 and 6, as well as 3 days/week during weeks 2 to 5 of a 6 week observation period. NAL was performed immediately after lung function measurement on Monday, Wednesday, and Friday during weeks 1 and 6 , and fluid was analyzed for inflammatory markers and total cells. Daily (TWA, $8 \mathrm{~h}$ ) personal exposure to airborne cotton dust was measured during weeks 1 and 6 of the observation period.

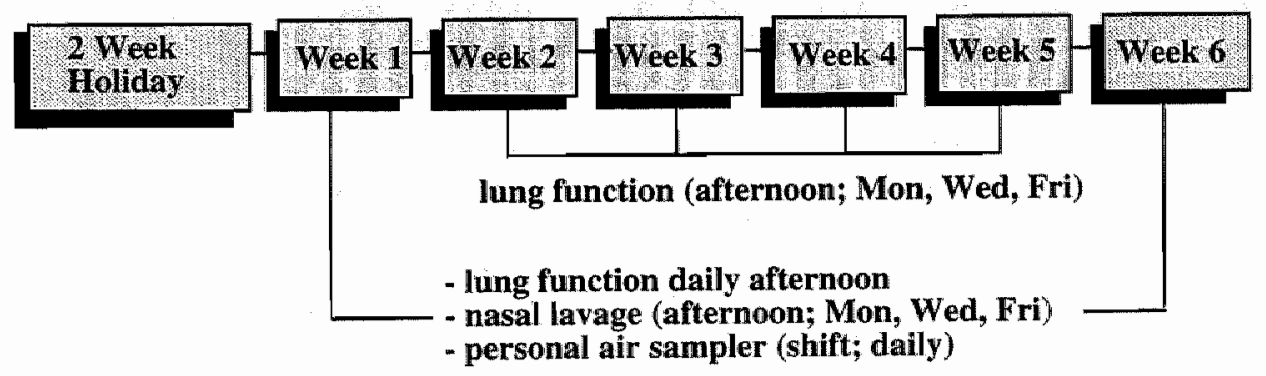

Figure 5.1. Design of a short-tem longitudinal study

Graphic illustration of the short-term longitudinal study anong exposed cotton dust workers in $1996(n=11)$. Lung function was measured daily in the afternoon $(1.00-3.00$ pmi during weeks 1 and 6; and 3 times, week (Monday. Wednesday, Friday) within weeks 2, 3, 4, and 5 using flow wolume curves. Nasal lavage was performed on Monday. Wednesday, and Friday afternoon during weeks 1 and 6 for determination of IL-6, IL-8, sTNF-R75, ICAM-1, uric acid, tolal and differential cell counts. During weeks 1 and 6 , daily personal exposive to (airborne) total cotton dust levels was determined by gravimetric measurement.

\section{Exposure Measurements}

Personal inhalable dust exposure was measured daily in weeks 1 and 6 in 11 workers, using portable air pumps (Dupont, P-2500) and PAS-6 samplers at a sampling rate of $2.0 \mathrm{~L} / \mathrm{min}$. Ambient cotton dust was sampled daily (TWA, $8 \mathrm{~h}$ ) only in week 1 at various sites of the plant. Total cotton dust concentrations were 
determined gravimetrically and the endotoxin content of the dust was determined using the limulus amoebocyte lysate (LAL) test. Details of endotoxin extraction methods and analyses are given elsewhere (Douwes et all., 1995).

\section{Lung Function}

Lung function measurements were performed daily between 1.00 and 3.00 pm in weeks 1 and 6 , and 3 times/week in weeks 2 to 5 of the observation period as described previously (Keman et al, 1996). In brief, forced expiratory flow volume curves were recorded according to European Community for Steel and Coal (ECSC) criteria using a Jaeger Pneumotachograph Type Masterscope (Wuerzburg, Germany). Three recordings of forced vital capacity within $5 \%$ or a $100 \mathrm{ml}$ range were obtained from each subject. Parameters derived from the flow volume curves were: forced vital capacity (FVC); forced expiratory volume in 1 second $\left(\mathrm{FEV}_{1}\right)$; peak expiratory flow volume (PEF); and maximal mid expiratory flow volume (MMEF). All flow volume values were related to the reference values of the ECSC (Quanjer, 1983) for individual diagnosis. Values amounting to less than $80 \%$ for the predicted values of $F E V_{1}$ reflected subjects with airway obstruction. The equipment was calibrated daily using a 1 liter calibrator tube. All subjects were measured using the same pneumotachograph (Masterscope 486, Jaeger Gmbh \& Co).

\section{Nasal Lavage}

NAL was performed according to a technique described by Steerenberg et al. (1996) directly after lung function measurements. In brief, the subjects, in sitting position, lifted their neck approximately $45^{\circ}$ backward and elevated their palate to close the nasopharynx. Then $5 \mathrm{ml}$ of $37^{\circ} \mathrm{C}$ sterile phosphate buffered saline solution $\left(0.9 \% ; \mathrm{Ca}^{2+}\right.$ and $\mathrm{Mg}^{2+}$ free) was instilled into each nostril with a 10 $\mathrm{ml}$ sterile polystyrene pipet, during which the subjects did not breath or swallow. After $10 \mathrm{~s}$, the subjects put their head forward and the NAL fluid was expelled passively into a $15 \mathrm{ml}$ centrifuge tube via a polyamide gauze filtered funnel to separate the mucus. The fluid was put on ice and centrifuged at $600 \mathrm{~g}$ for $10 \mathrm{~m}$ after its return to the laboratory ( $<4 \mathrm{~h}$ of performance). The supernatant was separated into eight aliquots $(500 \mu \mathrm{l})$ and immediately stored at $-76{ }^{\circ} \mathrm{C}$ until further analysis.

\section{Inflamintory Markers and Cell Counts}

IL-6 and IL- 8 concentrations in NAL fluid were determined by a modified specific enzyme-linked immunosorbent assay (ELISA) technique as described by Dentener et al. (1993) and Bouma et al. (1994). Soluble TNF-R75 was measured by a modified sandwich ELISA technique as described by Leeuwenberg et al. (1994). Soluble ICAM-1 was analyzed by ELISA as decribed by Leeuwenberg et al. (1992). The detection limits were $10 \mathrm{pg} / \mathrm{ml}$ for IL-6, $4 \mathrm{pg} / \mathrm{ml}$ for IL- $8,5 \mathrm{pg} / \mathrm{ml}$ for sTNF$\mathrm{R} 75$, and $0.3 \mathrm{ng} / \mathrm{ml}$ for sICAM-1. The uric acid concentration was determined using a colorimetric method with a staining reaction of phosphorus-wolfram acid (Synchron $\mathrm{CX}-7$, with Beckmann's reagent), and the albumin concentration was determined by turbidimetry (ARRAY, standard kits of Beckmann) in the 
Clinical Analytic Laboratory of the Maastrich Academic Hospital. In all $50 \mu l$ of the cell pellet remaining after centrifugation of the NAL fluid $(500 \mu l)$ was used after formalin $(50 \mu \mathrm{l}, 1.1 \%)$ fixation to determine the number of cells calculated as the number of total cells per lavage as well as the number of cells per milliliter of recovered fluid.

\section{Statistical Analysis}

All results are expressed as median values $\left(25^{\text {th }}\right.$ and $75^{\text {th }}$ percentiles) unless otherwise stated. Paired and unpaired comparisons and correlations of flow volume data, and inflammatory markers in NAL were made between weeks 1 and 6 of the observation period using Wilcoxon's matched-pairs signed-rank test, the Mann Whitney $U$ test, and the Spearman rank correlation test, chosen for reason of group size and data distribution. For each individual the weekly average was used as a mean of three different NAL values. Means values for coefficients of variation of inflammatory markers in NAL were calculated from mean squares obtained by analysis of variance (ANOVA) as described by Bolej et al (1995). All statistical analyses were done using SPSS for Windows 6.0.

\section{Results}

\section{Exposure and Population Characteristics}

Airborne cotton dust concentrations $(n=51)$ and endotoxin levels $(n=61)$ were best described by a log-normal distribution as is usually the case for occupational exposure data (K-S Lilliefors, both $\mathrm{p}>0.20$ ). Geometric mean (GM) airborne cotton dust concentrations $\left(1.32 \mathrm{mg} / \mathrm{m}^{3}\right)$ were at a moderate level, but endotoxin levels $\left(\mathrm{GM}=2,566 \mathrm{EU} / \mathrm{m}^{3}\right)$ were quite high. No statistically significant difference in cotton dust and endotoxin concentration were found between week 1 and week 6 (Table 5.1). The GM of stationary endotoxin levels ( $n=7$ ) measured in week 1 of the observation period were lower than the level found in personal air samples $\left(\mathrm{GM}=1,541 \pm 7 \mathrm{EU} / \mathrm{m}^{3}\right)$.

Table 5.1. Personal inhalable cotton dust concentrations and endotoxin levels measured in week 1 , week 6 , and total measurement period

\begin{tabular}{|l|c|c|c|}
\hline \multicolumn{1}{|c|}{ Parameter } & Week 1 & Week 6 & Total Average \\
\hline Cotton dust (mg/m $\left.{ }^{3}\right)$ & 22 & 29 & 51 \\
- Sample size & 1.11 & 1.10 & 1.10 \\
- Median & $0.16-18.25$ & $0.12-23.81$ & $0.12-23.81$ \\
- Range & $1.35 \pm 3.60$ & $1.30 \pm 3.10$ & $1.32 \pm 3.25$ \\
- GM GSD & 27 & 34 & \\
Endotoxin (EU/m & & 3193 & 2869 \\
- Sample size & 1808 & $555-36,387$ & $5.45-36,397$ \\
- Median & $5.45-33,696$ & $3,828 \pm 3$ & $2,566 \pm 5$ \\
- Range & $1,541 \pm 7$ & & \\
- GM GSD & &
\end{tabular}

No significant differences (Mann Whitney U test, p>0.05) between airborne coton dust and endotoxin concentration in week 1 and week 6 were present. 
The average age of the cotton workers was 46 years, and the duration of employment varied considerably (7-39 years). Only 1 of 11 workers had symptoms of chronic bronchitis, whereas another worker used medication for his nasal symptoms (Table 5.2). No asthmatic symptom was found among these workers. Only eight workers completed all tests in week 1 , whereas nine workers completed all tests in week 6 . Six workers completed all tests in both week 1 and week 6 . In all, 4 of 11 workers were smokers. Although average lung function values measured in cotton workers were considered normal, airway obstruction $\left(\mathrm{FEV}_{1}<80 \%\right)$ was detected in three subjects.

Table 5.2. Demographic and health characteristics of cotton workers

\begin{tabular}{|l|c|}
\hline Parameter & Cotton Workers $(n=11)$ \\
\hline General Characteristics & \\
- Age (yrs) & $46(30-57)$ \\
- Smoking (yes/no) & $4 / 7$ \\
- Duration of employment & $25(7-39)$ \\
\hline Respiratory Symptoms (yes/no) & $1 / 10$ \\
- Chronic bronchitis & $0 / 11$ \\
- Asthma & $1 / 10$ \\
- Medication & $3.6(1.9-6.0)$ \\
\hline Lung Function & $97.2(56.6-123.7)$ \\
- FEV 1 (1) & $4.6(3.0-7.6)$ \\
- FEV $\%$ (\%) & $8.8(6.2-11.6)$ \\
- FVC (1) & $4.4(1.1-7.6)$ \\
- PEF (1/s) & $3 / 8$ \\
- MMEF (1/s) & \\
- Airway Obstruction (yes/no) & \\
\hline
\end{tabular}

\section{Inflammatory Markers in Nasal Lavage}

In cotton workers the average recovery of fluid from NAL did not change during the study and was similar that obtained by Steerenberg et al. (1996) employing the same method $(7.4$ versus $6.6 \mathrm{ml})$. IL-8 and albumin levels were found to be correlated (Spearman rank test, $p<0.01$ ) to all other markers in NAL except uric acid and albumin, although the correlation coefficients were relatively low $(r<0.6, n=90)$. Interestingly, the highest degree of correlation was observed between albumin and sTNF-R75 ( $r=0.77)$, probably indicating their common source (exudation of plasma). Interestingly, total cells decreased significantly in week $6(\mathrm{p}<0.05)$ as compared to week 1 (Table 5.3$)$. Cell numbers were not correlated to any marker, including IL-8. Soluble ICAM-1 was detectable in one worker, typically showing airway obstruction and nasal secretions. Interestingly, IL-6, IL-8, and uric acid levels were higher in smokers than in nonsmokers, but only the difference in uric acid reached significance (Mann Whitney $U$ test, $p<0.05$ ). Endotoxin exposure levels were relatively lower in smokers as compared with non-smokers (Table 5.4). 
Table 5.3. Average values of inflammatory markers in nasall lavage of cotton workers

\begin{tabular}{|c|c|c|c|}
\hline $\begin{array}{c}\text { Marker } \\
\text { in Nasal Lavage } \\
\text { (Unit) }\end{array}$ & $\begin{array}{l}\text { Week } 1 \\
(N=8)\end{array}$ & $\begin{array}{l}\text { Week } 6 \\
(N=9)\end{array}$ & $\begin{array}{c}\text { Week if } 6 \\
(N=11)\end{array}$ \\
\hline$-\mathrm{IL}-6(\mathrm{pg} / \mathrm{ml})$ & $(0)^{\bar{z}}$ & $(2)^{2}$ & $(1)^{2}$ \\
\hline$-\pi \mathrm{L}-8(\mathrm{pg} / \mathrm{ml})$ & $726(505-1,006)$ & $943(460-1,584)$ & $756(484-1,147)$ \\
\hline - sTNF-R75 (pg/mi) & $(0)^{a}$ & $(1)^{a}$ & $(1)^{a}$ \\
\hline - s-ICAM-1 (ng/ml) & $(0)^{a}$ & $(0)^{\mathrm{a}}$ & $(0)^{a}$ \\
\hline - Uric acid ( $\mu \mathrm{mol} / \mathrm{l})$ & $33.0(31.0-36.0)$ & $34.5(29.0-38.8)$ & $33(30.0-37.0)$ \\
\hline - Albumin (mg/1) & $3.8(2.4-7.3)$ & $9.0(5.6-17.7)$ & $6.0(3.13-11.0)$ \\
\hline - Total cells $/ \mathrm{ml}\left(\times 10^{3}\right)$ & $0.4(0.0-1.1)$ & $0.001(0.0-0.001)^{b}$ & $0.004(0.0-0.4)$ \\
\hline - Recovery (ml) & $7.5(7.1-7.8)$ & $6.9(5.8-7.5)^{b}$ & $7.4(6.4-7.6)$ \\
\hline
\end{tabular}

Values are presented as median levels.

"Instead of range, the number of persons with repeatedly detectable levels are listed.

Significantly lower from week 1 (Mann Whitney $U$ test, $p<0.01$ ).

\section{Association of Inflammatory Markers with Exposure and Lung Function}

In none of the cotton workers was a significant correlation present between any inflammatory marker in NAL and one of the three following exposure indices of cotton dust or endotoxin exposure calculated as (i) PAS at the same day as NAL, (ii) cumulative exposure in the days preceding the NAL, and (iii) the cumulative week exposure. However, in six paired measurements of cotton workers sampled in week 1 and week 6 (illustrated in Fig.1) the levels of IL-8 and albumin in NAL tended to increase throughout the measurement period, beeing paralleled by an increasing endotoxin concentration, but not by the airborne cotton dust concentration. On the other hand, the number of total cells per milliliter of lavage fluid decreased significantly (Wilcoxon's matched-pairs signed-rank test, $\mathrm{p}<0.05$ ) from an average of 400 cells per milliliter in week 1 to 1 cell per milliliter in week 6 .

Markers in NAL were also compared among workers on the basis of their lung function response (Table 5.4). A lung function decrease was calculated as a statistically significant negative slope of the regression line of $\mathrm{FEV}_{1}$ along 6 weeks of observation $(n=21)$. Among 11 cotton workers, 5 had a significant lung function decrease and 6 showed no change in lung function. Chronic airway obstruction (defined as $\mathrm{FEV}_{1}<80 \%$ predicted) was found in 3 of 11 cotton workers. Most inflammatory markers in NAL (except albumin and cells) were relatively higher in cotton workers with lung function decrease, except for albumin and total cells. Interestingly, the epithelium-derived markers sTNF-R75, s-ICAM-1, and uric acid were consistently higher in workers with lung function response or airway obstruction. However, none of these trends reached statistical significance. 

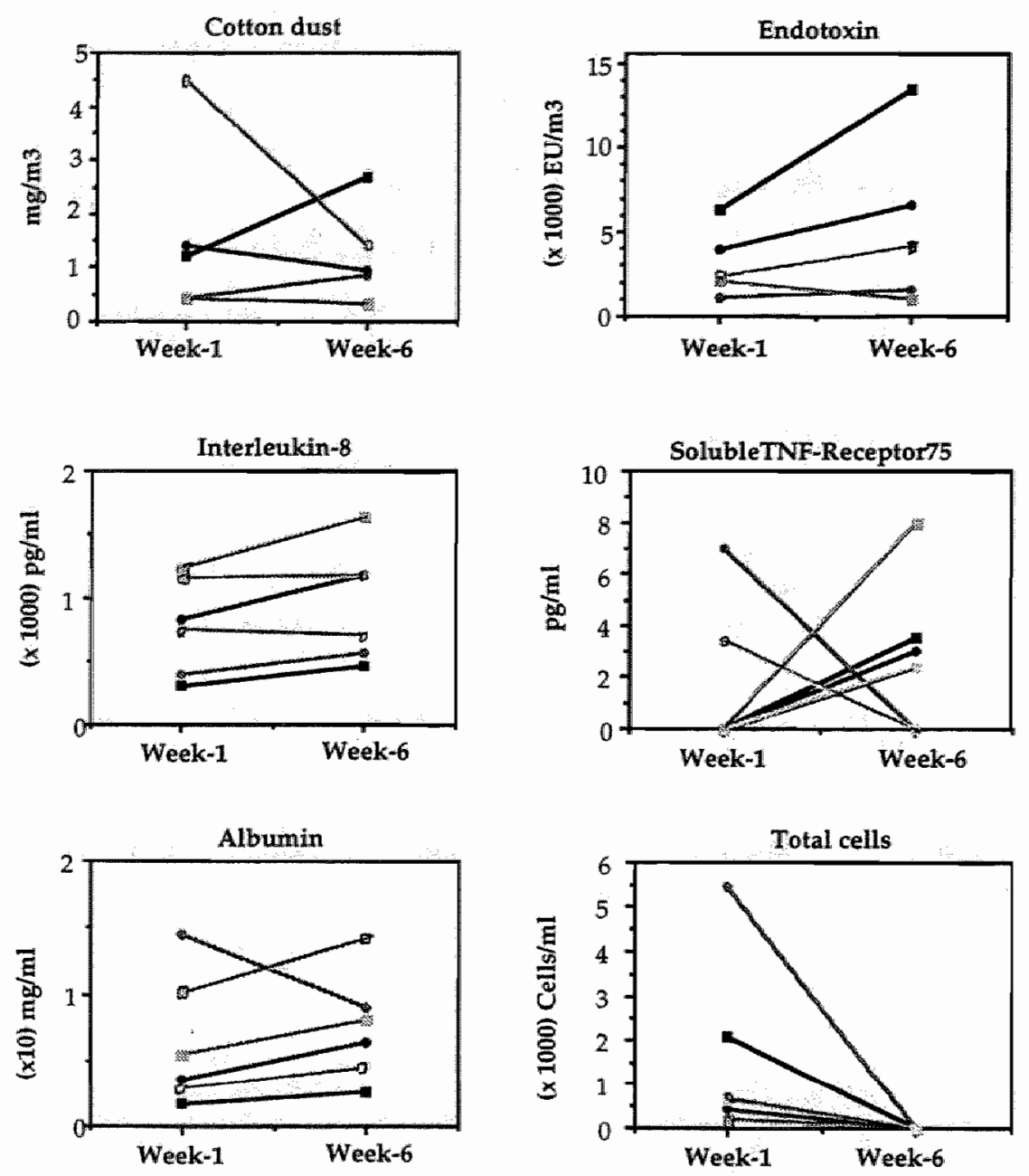

Figure 5.2. Exposure and NAL markers in week 1 and week 6

Graph illustrating the increase or decrease of cotton dust, endotoxin, $I L-8$, soluble TNF-R75, albunin, and total cells in six individuals that were measured both in week 1 and week 6 . Lines connect the data-points (average of 3 measurewents each week of the same subject. 


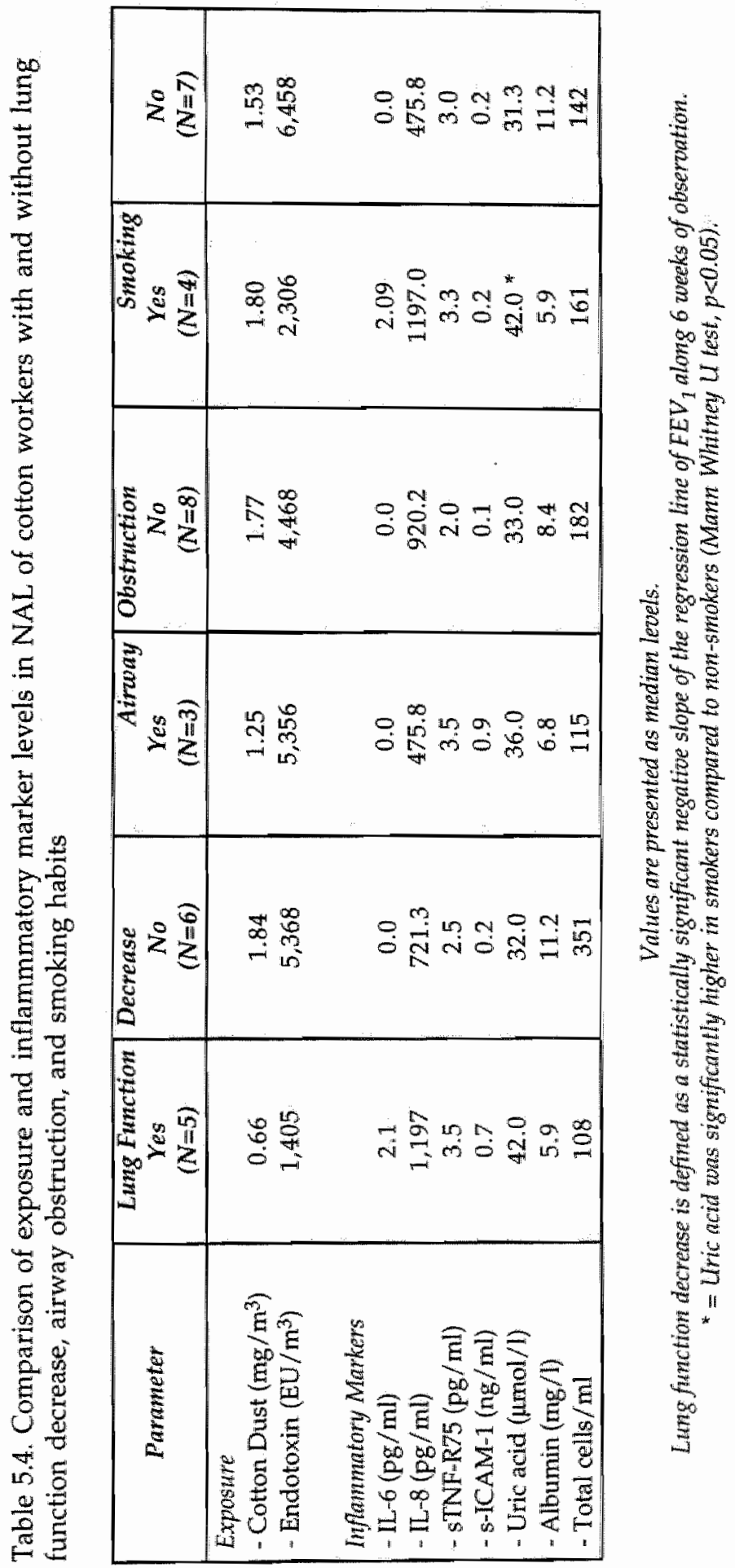




\section{Discussion}

In this study we applied NAL, as well as lung function and exposure measurements in a small group of cotton workers for 6 weeks after an exposure free period. The aim of this study was to evaluate changes in inflammatory markers in NAL in relation to endotoxin exposure and lung function changes. As in other studies, we experienced that the technique of NAL was simple, relatively non invasive, well tolerated, and without adverse side effects (Graham and Koren, 1990; Fischer et al., 1993), but was subject to high intra- and intervariability (Keman et al., 1997). Several new markers (sTNF-R75, sICAM-1) were measured along with the 'common' response markers ( $\mathrm{L}-8, \mathrm{~L}-6$, albumin, cells) in NAL fluid. In six paired measurements of cotton workers, the levels of IL-8, STNF-R75, and albumin tended to increase throughout the measurement period, beeing paralleled by an increasing endotoxin concentration, but not by airborne cotton dust levels. The levels of uric acid was significantly higher (Mann Whitney $\mathrm{U}$ test, $\mathrm{p}<0.05$ ) in smokers than in non-smokers, whereas the endotoxin exposure level was relatively lower in smokers as compared with non-smokers. Surprisingly, the number of total cells per milliliter decreased dramatically from an average of 400 cells $/ \mathrm{ml}$ in week 1 to 1 cell $/ \mathrm{ml}$ in week 6 .

Our mean coefficients of variation for IL-8, albumin, uric acid, and total cells are in the same range as that obtained in other studies using NAL (Graham and Koren, 1990; Hauser et al., 1995; Steerenberg et al., 1996), but reference data for sTNF-R75 are lacking, and those for IL-6 and soluble ICAM-1 are scarce. IL-6 was detected in 1 of 11 cotton workers. Other reports showed that IL-6 was detectable in only 1 of 12 subjects (Steerenberg et al., 1996) and primary nasal epithelial cells of 12 normal volunteers did not produce IL-6 protein or mRNA message (Becker et al., 1993) either at baseline or after stimulation with respiratory syncitial virus. IL-6 was detected repeatedly in 1 of 11 cotton workers. Soluble ICAM-1 was detectable ( $>2$ times the detection limit, $0.3 \mathrm{ng} / \mathrm{ml}$ ) in a number of samples but was repeatedly detectable in only one subject. Other reports showed soluble ICAM-1 in NAL of controls (about $20 \mathrm{ng} / \mathrm{ml}$ ) and subjects with pollen induced rhinitis (about $50 \mathrm{ng} / \mathrm{ml}$ ), with serum levels being similar $(200 \mathrm{ng} / \mathrm{ml}$ ) (Kato et al., 1995). The significance of adhesion molecule shedding is not clear but it may have profound implications on the adhesion of activated polymorphonuclear neutrophilic cells (PMNs) at exposure to endotoxin.

IL-8 was readily detectable in most lavage samples and seemed to be associated with endotoxin exposure. Although it can be produced by several cell types in the nose, epithelial cells are probably the main source of IL- 8 in NAL in response to a variety of stimuli. Increased IL-8 levels have been observed in studies on ozone exposed subjects (Steerenberg et al., 1996; Hiltermann et al., 1996) or after challenge with swine dust extracts (Palmberg et al., 1994). Although IL-8 tended to increase in NAL of cotton workers, the number of total cells decreased significantly throughout the measurement period. Most studies have reported increased numbers of NAL cells in subjects exposed to organic dusts (Wang et al., 1996; Ahman et al., 1995; Blaski et al., 1996) or other inflammatory agents. A few methodological issues could have contributed to our results, including an increase in nasal obstruction in cotton workers due to exposure. 
This is supported by the higher recovery of NAL fluid in cotton workers, the fluid not reaching the ethmoidal compartments to wash out cells. An effect of cotton dust components on mucous viscosity and the resulting lower recovery of cells by filtering also cannot be excluded. Most likely, however, is that the decrease in the number of cells in week 6 can be explained by an activation of PMNs by continuously high levels of endotoxin exposure (median: $2,869 \mathrm{EU} / \mathrm{m}^{3}$ ) in combination with the performance of fixation too late ( $5 \mathrm{~h}$ after lavage). This may have resulted in cell death and lysis before fixation. Cell counts in NAL done by aspiration in grain workers exposed to similar endotoxin levels $(2,373$ $\mathrm{EU} / \mathrm{m}^{3}$ ) have shown increased cellularity relative to controls (Blaski et al., 1996).

The paired analysis of six cotton workers who were studied in both weeks showed an increasing trend for IL-8, sTNF-R75 and albumin concentrations paralleled by endotoxin exposures (Fig 2). Although it is difficult to interpret such data mechanistically, they fit the concept that inhaled endotoxin produces its effects through the initial release of inflammatory mediators from the epithelium (TNF, IL-8, sTNF-R75), although other components (e.g., glucans) can not be excluded (Rylander et al., 1989). Plasma exudation (albumin) and oxidative stress (uric acid) are supposed to be secondary to these events. Interestingly, levels of the epithelium-derived markers STNF-R75, s-ICAM-1, and uric acid were consistently higher in workers with lung function decrease or airway obstruction. On the other hand, L -8 showed a different pattern between workers with and those without chronic airway obstruction.

In conclusion, our data suggest that changes in inflammatory markers in NAL are related to endotoxin exposure. Although most nasal inflammatory markers seem to be associated with short-term lung function changes, no conclusion can be drawn with regard to this aspect. To date, such a relationship has been demonstrated only in studies on patients with asthma or allergic rhinitis. The correlation of lung function response to changes in nasal markers will require further longitudinal studies among larger study groups exposed to organic dusts or respiratory irritants.

\section{Acknowledgements}

The authors are seriously indebted to all the workers for their participation in this study. and to Conny Beckers MD, and Hans wan der Leeww for thetr assistance in the workplace survey. The authors also thank Inge Wouters MSc for her assistance for exposure measurements, Roger Moonen for soluble ICAM-1 measurements, Roel PF Schivs PhD for his assistance during measurement of inflammatory markers in the supermatant of NAL Auid, Prof. Jos Kleinjans, Ph.D. for critically reviewing the manuscript, and the department of Epidemiology and Public Health, Wageningen Agricultural University for the dust sampling equipment. 


\section{References}

Ahman M, Holmstrơm M, Ingelman-Sundberg H (1995) Inflammatory markers in nasal lavage fluid from industrial arts teachers. Am I Ind Med 28:541-550.

Beck GI, Schachter EN, Maunder LR, Schilling SF (1982) A prospective study of chronic lung disease in cotton textile workers. Ann Intern Med 97:645-651.

Becker S, Koren HS, Henke DC (1993) Interleukin-8 expression in normal nasal epithelium and its modulation by infection with respiratory syncytial virus and cytokines tumor necrosis factor; Interleukin-1, and Interleukin-6. Am J Respir Cell Mol Biol 8:20-27.

Blaski CA, Watt JL, Quinn T], Thorne PS, Schwartz DA (1996) Nasal cellularity, grain dust and airflow obstruction. Chest 109:1086-1092.

Boleij I. Buringh $\mathbb{E}$, Heederick D, Kromhout $H$ (1995) Occupational hygiene of chemical and biological agents. Amsterdam: Elsevier Science, pp.97-136.

Borm PJA, Schins RPF, Derhaag TJJM, Kant IJ (1996) Cross-shift changes in blood inflammatory markers occur in the absence of airway obstruction in workers exposed to grain dust. Chest 109:1078-1083.

Bouma MG, Stad RK, Wildenberg AJM vd (1994) Differential regulatory effects of adenosine on cytokine release by activated human monocytes. J Immunol 153:4159-4168.

Castellan $\mathbb{R M}$, Olenchock SA, Hankinson JL, Millner PD, Cocke JB, Braagg K, Perkins HH, Jacobs RR (1984) Acute bronchoconstriction induced by cotton dust: dose related responses to endotoxin and other dust factors. Ann Intern Med 101:157-163.

Christiani DC, Ye TT, Wegman DH, Eisen EA, Dai HL, Lu PL (1994) Cotton dust exposure, across-shift drop in $\mathbb{F E V}_{1}$, and five-year change in lung function. Am J Respir Crit Care Med 150:1250-1255.

Clapp WP, Becker S, Quay J, Watt $\mathrm{L}$, Thorne PS, Frees KL, Zhang X, Koren HS, Lux CR, Schwartz DA (1994) Grain dust induced airflow obstruction and inflammation of the lower respiratory tract: Am J Respir Crit Care Med 150:611-617.

Dentener MA, Basil V, Von Asmuth EJU (1993) Involvement of CD14 in lipopolysaccharide-induced tumor necrosis factor $\alpha$, IL-6, and IL- 8 release by human monocytes and alveolar macrophages. J Immunol 150:2885-2891.

Devlin RB, McDonnell WF, Mann R, Becker S, House DE, Schreinemachers D, Koren HS (1991) Exposure of humans to ambient levels of ozone for $6.6 \mathrm{~h}$ causes cellular and biochemicall changes in the lung. Am J Respir Cell Mol Biol 4:72-81.

Douwes J, Versloot P, Hollander A, Heederick D, Doekes G (1995) The influence of various dust sampling and extraction methods on the measurement of airborne endotoxin. Appl Environ Microbiol 61:1763-1769.

Fischer TM. Kuehr J, Pullwitt A, Meinert R, Forster J, Studnicka M, Koren HS (1993) Ambient ozone causes upper airways inflammation in children. Am rev Respir Dis 148:961964. 
Graham DE and Koren $\mathrm{HS}$ (1990) Biomarkers of inflammation in ozone-exposed humans: comparison of the nasal and bronchoalveolar lavage. Am Rev Respir Dis 142:152-156.

Hauser R, Elreedy S, Hoppin JA, Christiani DC (1995) Upper airway response in workers exposed to fuel oil ash: nasal lavage analysis. Occup Environ Med 52,353-358.

Hiltermann JTN, de Bruijne CR, Fischer PH, Ameling CB, Hiemstra PS, Dijkman JH, Stolk J, Bree L van (1996) Association between summer air pollution, respiratory symptoms, and Interleukin-8 in nasal lavage fluid of asthmatics. Am J Respir Crit Care Med 153:A304.

Kato M, Hattori T, Kitamura M, Beppu $\mathrm{R}_{r}$ Yanagita $\mathrm{N}_{s}$ Nakashima I (1995) Soluble ICAM-1 as regulator of nasal allergic reaction under natural allergen provocation. Clin Exp Allergy 25:744-748.

Keman S, Willemse B, Wesseling GJ, Kusters E, Borm PJA (1996) A five year follow-up of lung function among chemical workers using flow-volume and impedance measurements. Eur Respir J 9:2109-2115.

Keman $S_{s}$ Jetten M, Schün RPF, Borm PJA (1997) Relation between inflammatory markers in serum and nasall lavage. Exp Toxicol Pathol, In press.

Kilburn KH (1994) Byssinosis: causes and practical control. Ann Intern Med 101:252-253.

Kips JC, Tavernier J, Pauwels RA (1992) TNF causes bronchial hyperresponsiveness in rats. Am Rev Respir Dis 145:332-336.

Kunkel SL, Chensuie SW, Standiford Tj, Strieter RM (1994) Endotoxin-dependent cytokine networks. In: Brigham KL, (ed.) Endotoxin and the lungs: New York, Marcel Dekker, pp. 305-320.

Larsson KA, Eklund AG, Hansson LO, Isaksson BM, Malmberg PO (1994) Swine dust causes intense airways inflammation in healthy subjects. Am J Respir Crit Care Med $150: 973-977$.

Leeuwenberg JFM, Smeets EF, Neefjes J], Shaffer MA, Cinek I, Jeunhomme TMAA, Ahern TJ, Buurman WA (1992) E-selectine and intercellular adhesion molecule-1 are released by activated human endothelial cells in vitro. Immunology 77:543-549.

Leeuwenberg JFM, Jeunhomme TMAA, Buurman WA (1994) Lipopolysaccharide LPSmediated soluble TNF receptors release and TNF receptor expression by monocytes. J Immunol 152:5070-5076.

Merchant JA, Lumsden JC, Kilburn KH, O'Fallon WM, Ujda JR, Germino VH, Hamilton JD (1973) An industrial study of the biological effects of cotton dust and cigarette smoke exposure. ] Occup Med 15:212-221.

Michel O, Ginami $R_{r}$ LeBon $B_{*}$ Content J, Duchateau J, Sergysels R (1992) Inflammatory response to acute inhalation of endotoxin in asthmatic patients. Am Rev Respir Dis. $146: 352-357$.

Palmberg L, Isaksson. BM, Larsson K, Malmberg P (1994) Swine dust is more potent than LPS to induce Interleukin-8 production in a pulmonary epithelial cell line. Eur Respir I 7:73s. 
phosphate buffered saline in each nostril (10 sec, passive). The gauze-filtered fluid was put on ice, subsequently centrifuged at $600 \mathrm{~g}$ for 10 minutes, and separated into 8 aliquots $(500 \mu \mathrm{ll})$ and immediately stored at $-76{ }^{\circ} \mathrm{C}$ until further analysis. Inflammatory marker assays. IL-4, IL-5, and IFN- $\gamma$ were determined using chemiluminescence ELISA as described by Tollerud et al. (1994). Detection limits were: $2.5 \mathrm{pg} / \mathrm{ml}$ for $\mathrm{IL}-4,1.25 \mathrm{pg} / \mathrm{ml}$ for IL-5 and IFN- $\gamma$. IL-6, IL-8, sTNF-R75, LBP, and BPI were determined applying sandwich ELISAs technique as described previously by Borm et al. (1996). Soluble ICAM-1 was analyzed by ELISA as described by Leeuwenberg et al. (1992). The detection limit was $10 \mathrm{pg} / \mathrm{ml}$ for IL-6, $4 \mathrm{pg} / \mathrm{ml}$ for $\mathrm{IL}-8,5 \mathrm{pg} / \mathrm{ml}$ for sTNF-R75, and $0.3 \mathrm{ng} / \mathrm{ml}$ for sICAM-1. Uric acid was conducted using a colorimetric method with a staining reaction of phosphorwolfram acid (Synchron CX-7, with Beckmann's reagent) and albumin concentration both in serum and NAL were determined by turbidimetry (ARRAY, standard kits of Beckmann). Statistical Analysis. All results are expressed as median (25 th $7^{\text {th }}$ percentiles), unless otherwise stated. Correlation between markers in serum and/or NAL were tested by Spearman rank correlation test, chosen for reason of group size and data distribution. All statistical analyses were done using SPSS for Windows 6.0 .

\section{Results and Discussion}

Most inflammatory markers both in controls and cotton workers were readily detectable in serum (Table 6.1), but not in NAL, except for the proinflammatory IL-8. IL-8 was detectable in nearly all NAL samples, while IL-6 was only detectable in a fraction (3/28), and IL-4, IL-5 and IFN- $\gamma$ in one case. These data are consistent with other studies showing detectable IL-6 in a minor fraction of subjects (Steerenberg et al., 1996; Wang et al., 1997).

Table 6.1. Median levels of inflammatory markers in serum and NAL of cotton workers $(\mathrm{n}=11$ )

\begin{tabular}{|c|c|c|}
\hline Parameter & Serum & NAL \\
\hline$\overline{\mathrm{IL}}-6(\mathrm{pg} / \mathrm{ml})$ & $66.0(20 / 32)$ & $0.0(3 / 28)$ \\
\hline $\mathrm{L},-8(\mathrm{pg} / \mathrm{mll})$ & $0.0(0.0 \cdot 10.5)(8 / 33)$ & $729.0(433.0-1,224.0)$ \\
\hline $\mathrm{IL}_{\omega}-4(\mathrm{pg} / \mathrm{m})$ & $3.6(1.4-5.0)$ & ND \\
\hline $1 \mathrm{~L}-5(\mathrm{pg} / \mathrm{mul})$ & $6.8(3.6 \times 16.5)$ & ND \\
\hline IFN $=(\mathrm{pg} / \mathrm{ml})$ & $1.9(1.7-2.9)$ & ND \\
\hline S-ICAM $(\mathrm{ng} / \mathrm{ml})$ & $162.3(132.3-186.3)$ & $0.0(8 / 24)$ \\
\hline s-TNF-R75 (pg/ml) & $2,368(1,456-3,070)$ & $0.0(6 / 28)$ \\
\hline Albumin (mg/l) & $\ldots$ & $6.0(3.7-11.1)$ \\
\hline Uric acid ( $\mu \mathrm{mol} / \mathrm{l})$ & $\cdots$ & $33.0(31.0-39.0)$ \\
\hline $\mathrm{LBP}^{\mathrm{B}}(\mathrm{pg} / \mathrm{ml})$ & $29,000(17,000-37,000)$ & $786.0(304.9-2,203.5)$ \\
\hline $\mathrm{BPI}(\mathrm{pg} / \mathrm{ml})$ & $1,890(875-2,593)$ & $476.0(18.0-1,313.5)$ \\
\hline
\end{tabular}

Serum values in cotton workers ( $n=11$ ) were measured at four different points over 6 weeks. Values between brackets represent $\left(25^{\text {th }}-75^{\text {th }}\right.$ percentiles); or the relative ratio of detectable samples out of all measurements. ND: not detectable; for detection limits see methods; --: no data, not determined. 
Endotoxin binding proteins (LBP and BPI) were readily detectable in both serum and NAL. Although LBP is mainly synthesized in the liver (Dentener et al., 1997), some minor evidence for extra-hepatic synthesis in sepsis is present. This implies that LBP in NAL is the result of plasma exudation. Interestingly, LBP in NAL is negatively correlated to serum levels (Table $6.2 ; \mathrm{r}=-0.88$ ) in controls. Another LPS binding protein (BPI) is mainly produced by activated polymorphonuclear (PMN) cells (Dentener et al., 1997). Considering the large fraction of PMN in the NAL $(>80 \%)$, it is not surprising that BPI is correlated to IL-8 in NAL as the major chemoattractant for PMN.

Table 6.2. Coefficients of correlation between inflammatory markers in serum and NAL

\begin{tabular}{|l|c|c|c|}
\hline Inflammatory Marker & Controls & Cotton workers & All Subjects \\
\hline IL-6 (pg/ml) & $0.33(9)$ & $0.29(23)$ & $0.27(32)$ \\
IL-8 (pg/ml) & $0.30(9)$ & $0.13(23)$ & $-0.00(32)$ \\
S-ICAM (ng/ml) & $a$ & $-0.15(18)$ & $-0.15(18)$ \\
S-TNF-R75 (pg/ml) & $-0.05(7)$ & $-0.48(21)$ & $-0.38(28)$ \\
Albumin $(\mathrm{mg} / 1)$ & $0.42(9)$ & - & $0.42(9)$ \\
Uric acid $(\mu \mathrm{mol} / 1)$ & $0.41(9)$ & $-.0 .41(9)$ \\
LBP $(\mathrm{pg} / \mathrm{ml})$ & $-0.88(7) *$ & $-0.04(14)$ & $-0.34(21)$ \\
BPI $(\mathrm{pg} / \mathrm{ml})$ & $0.07(7)$ & $0.43(18)$ & $0.11(25)$ \\
\hline
\end{tabular}

Coefficients of correlation (Spearman Rank Correlation test); If significant, ${ }^{*}=p 0.05$ $a=$ Correlations for IL-4, IL-5, IFN- $\gamma$ could not be calculated since not detectable in NAL, only in serum (see also Table 6.3). In brackets are the number of paired (serum and NAL) measurements.

Correlation with albumin and uric acid (Table 6.3) possibly reflect a secondary effect of PMN on upper respiratory epithelial cells, causing oxidative stress and release of these molecules. The positive correlation between LBP and BPI is rather unexpected considering their different source, but understandable from their biological function as LPS-binding (ant)agonists in relation to endotoxin in cotton dust exposure. The strongest relation between serum and NAL was observed for the $75 \mathrm{kD}$ part of soluble form of the membrane associated type II (or $80 \mathrm{kD}$ ) TNF receptor (sTNF-R75). The biological role of sTNF-R75 is dose-dependent, but we suggest that these levels in NAL prevent binding from TNF- $\alpha$ to membrane receptors, thereby counterbalancing proinflammatory chemokine effects. No (free) TNF- $\alpha$ was detectable in NAL (detection limit 10 $\mathrm{pg} / \mathrm{ml}$; data not shown). It should be noted, however, that STNF-R75 was only detectable in NAL of 6 out of 23 measurements. In conclusion, only markers predominantly present in serum showed a significant correlation with NAL levels, confirming plasma exudation as its main source. On the other hand, markers with predominant epithelial (IL-8) or granulotype (BPI) origin were also related to LBP and sTNF-R75, thereby impeding a clear-cut interpretation as nasal biomarker. Experimental and clinical studies are needed to further understand 
the major sources and significance of inflammatory markers in the upper airways.

Table 6.3. Correlation between different inflammatory markers in NAL of cotton workers

\begin{tabular}{|c|c|}
\hline Parameter & Correlated with \\
\hline $\begin{array}{l}1 \mathrm{~L}-6 \\
\mathrm{IL}-8 \\
\mathrm{LBP} \\
\mathrm{BPI} \\
\text { Urice acid }\end{array}$ & $\begin{array}{l}\text { S-ICAM }(0.56)^{* * *} \text {. } \\
\text { Albumin }(0.47)^{*} \text {, BPI }(0.66)^{* * *} \text {, LBP }(0.64)^{* *} \text {, Uric acid }(0.53)^{* * *} \text {. } \\
\text { Albumin }(0.52)^{* * *} \text {, BPI }(0.56)^{* *} \text {, IL-8 }(0.64)^{* * *} \\
\text { Albumin }(0.62)^{* *}, \text { IL-8 }(0.66)^{* *} \text {, LBP }(0.56)^{* *} \text {, Uric acid }(0.57)^{* * *} \text {. } \\
\text { BPI }(0.57)^{* *}, \text { IL-8 }(0.53)^{* *}\end{array}$ \\
\hline
\end{tabular}

In brackets are coefficients of correlation.

Sigrificances were tested by Spearman's rank correlation test, ${ }^{*}=p<0.05 ;{ }^{* *}=p<0.01$.

\section{Acknowledgements}

The authors are seriously indebted to all the workers and control volunteers for their participation in this study, and to Conny Beckers $M D$, and Hans oan der Leeww for their assistance in the workplace survey. The authors also thank David J. Tollerwd, MD, MPH. (Centes for Environmental and Occupational Health, University of Allegheny. School of Public Health,

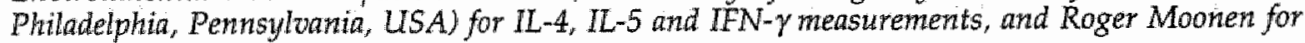
soluble ICAM-1 measurements.

\section{References}

Blaski CA, Watt J, Quinu T], Thorne PS, Schwartz DA (1996) Nasal cellularity, grain dust and aurflowobstruction. Chest 109:1086-1092.

Borm PJA, Schins RPF, Derhaag TJJM, Kant IT, Joma THJM (1996) Cross-shift changes in blood inflammatory markers occur in the absence of airway obstruction in workers exposed to grain dust. Chest 109:1078-1083.

Dentener MA, Francot GJM, Hiemstra PS, Tool ATJ, Verhoeven AJ, Vandenabeele P, Buirman WA (1997) Bactericidal/permeability-increasing protein release in whole blood exviwo: strong induction by lipopolysaccharide and tumor necrosis factor- $\alpha$. J infect 175 :108117.

Devlin RB, McDonnell WF, Mann R, Becker S, House DE, Schreinemachers D, Koren HS (1991) Exposure of human to ambient levels of ozone for $6.6 \mathrm{~h}$ causes cellular and biochemical changes in the lung. Am J Respir Cell Mol Biol 4:72-81. 
Hauser R, Garcia-Closas M, Kelsey KT, Christiani DC (1994) Variability of nasal lavage polymorphonuclear leukocyte counts in unexposed subjects: Its potential utility for epidemiology. Arch Environ Health 49:267-272.

Leeuwenberg JFM, Smeets EF, Neefjes J], Shaffer MA, Cinek T, Jeunhomme TMAA, Ahern TJ, Buurman WA (1992) E-selectine and Intercellular adhesion molecule-1 are released by activated human endothelial cells in vitro. Immunol 77:543-549.

Persson CGA, Svensson C, Greiff L, Andersson M, Wollmer P, Alkner U, Erjefalt I (1992) Editorials: The use of the nose to study inflammatory response of the respiratory tract. Thorax 47:993-1000.

Streerenberg PA, Fischer PH, Meyling FG, Willighagen J, Geerse E, Van de Vliet $H$, Ameling C, Boink ABTJ, Dormans JAMA, Van Bree L, Van Loveren H (1996) Nasal lavage as a tool for health effect of photochemical air pollution. Hum Exp Toxicol 15:111-119.

Tollerud DJ, Sparrow D, Weiss S, Guevarra L. (1994) Chemiluminescence assay for human cytokines. J Cell Bioch 18 (Suppl.):A-26.

Wang Z, Larsson K, Palmberg L, Malmberg P, Larsson P. Larsson L (1997) Inhalation of swine dust induces cytokine release in the upper and lower airway. Eur Respir J 10:381-387. 


\section{Chapter 7}

\section{GENERAL DISCUSSION}

The contribution of occupational exposures to the pathogenesis of respiratory diseases is still underestimated (Becklake, 1989-a,-b), but certainly under recognized in the practice of clinical and occupational medicine (Morgan, 1986). Occupational asthma is the most frequently diagnosed occupational lung disease reported to the SWORD scheme (Ross et al., 1995). Recent data suggest alarming upward trends in the morbidity, mortality and cost of illness related to asthma and COPD (Weiss et al., 1992; Adam and Benson, 1992). Occupational lung diseases are rarely as specific as they used to be, but arise in more susceptible workers, and the pathogenesis is still not entirely clear. This is one reason why research in this field needs multi-scientific discipline approaches to achieve understanding and subsequently solving the problem. Recently, molecular epidemiology has been developed to illuminate disease mechanism. In these studies, we applied a multifunctional approach integrating occupational exposure measurement, lung function mesaurements, standardized questionnaires on respiratory symptoms, and several biological (disease) markers to detect chronic non-specific airway diseases (CNSAD), with special interest in occupational asthma and chronic bronchitis. Assessment of inflammatory markers both in blood and nasal lavage (NAL) fluid was done intensively in order to use inflammatory markers as an alternative or as a complementary tool to detect these diseases in occupational setting.

Classic tools such as flow volume curves and standardized questionnaires on respiratory symptoms have serious shortcomings for early detection of (CNSAD) and discerning susceptible individuals. It is noteworthy, in a five year follow-up study among chemical workers (Chapter 2) demonstrated that alteration in impedance parameters reflect changes in flow volume curves longitudinally. It showed that in a population with normal changes in flow volume parameters, changes in impedance parameters although not always significant, followed these alterations as predicted by the model interpretation according to Wouters (1990). The lack of longitudinal significance is probably explained by the larger short term and long term variability in FOT derived parameters. A previous study in a small group $(n=10)$ of grain workers showed similar outcome at 2-year follow-up (Borm et al., 1996). Individual repeatability of R8 in our hands was slightly better compared to data published by Neild et al. (1989) for $Z_{3 \mathrm{~Hz}}(11.3 \%)$, or Stanescu et al. (1975) for $\mathrm{R}_{3-9 \mathrm{~Hz}}(12.0 \%)$ for short-term variability. Our coefficients of variation for $R 8(10.5 \%), X 8(14.6 \%)$, and $f_{0}(14.3 \%)$ would allow minimal detectable changes much smaller than those observed over five years in this cohort. This probably means that long-term variation is larger in impedance than flow volume parameters. This is in agreement with lower sensitivity of forced oscillation technique compared to flow volume. Although a high variability is present in frequency dependence, it is a very sensitive parameter to detect airway obstruction. This is, however, not based on the exact value, but upon the difference between a negative (airway obstruction) 
and a positive (normal) value. These data can be regarded as a valuable extension to the results found in cross-sectional studies in occupational settings. Therefore, impedance measurement using the FOT should be listed as a supplement method to detect airway obstruction in occupational settings, since alteration in impedance parameters reflect changes in flow volume curves longitudinally but has an additional value in the mechanical characteristics.

Another interesting finding is that two independent studies (Chapter 3 and 4) in chemical workers and coal miners demonstrated a relation between blood IL-8 and respiratory symptoms of (acute and chronic) bronchitis. This finding remained significant after correction for age and pack-years (logistic regression, $\mathrm{p}<0.05$ ) or number of white blood cells. A secondary analysis with a matched group verified these specific effects in this group. The finding that blood IL-8 release is significantly higher in workers with acute and chronic bronchitis is consistent with the role of this cytokine as a chemoattractant of neutrophils. IL-8 (and TNF- $\alpha$ ) has been shown to be increased in sputum (Richman-Eisenstat et al., 1993; Keating et al., 1996) and bronchial lavage fluid (Riise et al., 1995) of patients with chronic bronchitis, and plays an important role in the development of clinical respiratory disease (Donnelly et al., 1993; Broaddus et al., 1992; Lynch et al., 1992). Inflammation of the central airways is a prominent feature in subjects with chronic bronchitis. The pathology of chronic bronchitis includes an inflammatory mononuclear infiltrate in the airway wall and a neutrophil influx into the airway lumen, that produce the inflammation and induce mucus hypersecretion. There is growing evidence incriminating neutrophil and lymphocytes constituents in the initiation and maintenance of cough and mucus expectoration that occurs in subjects with chronic bronchitis (Hoidal, 1994). Whole blood IL-8 production may be considered as a useful marker for bronchitis, but can not rule out the involvement of other cytokines. Unfortunately, no data support the widespread use of blood cytokines as a tool for screening in occupational practice. The finding that blood spontaneous IL-8 release in workers with bronchitic symptoms seems very promising and giving an opportunity in application of molecular epidemiology into future of researches in the occupational setting.

It has become increasingly clear that cytokines have a pivotal role in the pathogenesis of asthma. BAL fluid of asthmatic patients contain significantly higher IL-4 and IL-5 (Walker et al, 1994) and mRNA for these cytokines appear to be expressed predominantly by $\mathrm{Th}_{2}$ lymphocytes (Robinson et al., 1992). These cytokines and IFN- $\gamma$ may be crucial to the regulation of immunoglobulin-E (IgE) biosynthesis (Arm and Lee, 1992). IL-4 is acting as a crucial factor for the differentiation of $T h_{0}$ into $T h_{2}$ cells and stimulates autocrine growth of $T_{2}$ lymphocytes (Mosmann and Coffman, 1989). IL-4 has been defined as a switch factor for IgE synthesis through regulation of transcription of the germline $C$ gene (Vercelli, 1995). Increased endogenous production of IL-4 suppress IFN- $\gamma$ production in patients with bronchial asthma which may leads to the overproduction of IgE (Kou et al., 1994). IL-5 appears to be a crucial cytokine for inducing and activating eosinophil infiltration into the asthmatic airways, most likely via an effect on eosinophyl growth and differentiation (Hessel et al., 1997). However, no evidence was found for the 'Th ${ }_{2}$ hypothesis' (increased IL-4, IL-5; 
decreased IFN- $\gamma$ ) in serum of chemical workers with asthmatic symptoms, but the number of asthmatics $(n=8)$ was probably too low (Chapter 3 ). No correlation was present between specific cytokines and lung function or airway obstruction. Serum IL-4 (but not blood IL-8) was increased in workers exposed to NPP fertilizer dust compared to the other workers, and serum IL-5 was decreased in workers exposed to various chemicals. No effects on those cytokines were noted in chemical workers exposed to potent respiratory sensitizer such as isocyanate derivates and polymeric dust. The complexity and low levels of the exposure in this study do not allow to specify a relationship between low incidence of occupational asthma and cytokines or specific chemical agents.

Inflammatory mediators were not only studied in peripheral blood but also in compartment which often suggests to reflect respiratory responses, i.e. in the nose. Nasal lavage (NAL) can be used to obtain cells and fluid from the nasal cavity and nasopharyngeal region. Nowadays, NAL is frequently used to study inflammatory response in the upper respiratory tract which may be similar to the response of bronchial mucosa, since many of cell types found in both regions are the same or similar. Compared to bronchoalveolar lavage (BAL), the NAL technique is non-invasive, well-tolerated, low cost and useful in field studies, but subject to high intra- and inter-individual variabillity. Detailed analyses of the upper airway have shown that the upper airway is immunocompetent ${ }_{r}$ and that migrating and structural cells have the capacity to produce and release mediators and cytokines (Persson et al., 1992). IL-8 is again an interesting marker (Chapter 5 ), although there is still considerable debate about the exact source of this cytokine in the nose. This question is indirectly answered in Chapter 6 , studying correlations between IL-8 in NAL and serum as well as cross-correlations with other inflammatory markers. These data indicate that IL-8 is the result of both plasma exudation and nasal epithelial cell release. This data fit the concept that inhaled endotoxin induces inflammatory effects in the respiratory tract. Several studies have shown that IL-8 is also increased in asthmatic children and viral acute upper respiratory infection (Noah et al., 1995-a; -b). Interestingly, uric acid was significantly higher (Mann Whitney $U$ test, $p<0.05$ ) accompanied by increasing IL-8 in smokers compared to non-smokers confirmed the role of smoking (probably amplified by endotoxin) in inflammatory effect and formation of reactive oxygen species in the upper airway. Moreover, an association between exposure to ozone, acid aerosols, or organic dust, and acute or chronic upper airway inflammation. (Devlin et al., 1991; Hauser et al., 1994; Blaski et al., 1996). The data support futher evaluation of IL-8 as a NAL marker of endotoxin exposure.

Asthma is regarded as a disease with a complex interaction between environmental and genetic factors. Possibilities for treating or, ideally, avoiding hereditary diseases have increased enormously with the rapid and radical developments in the field of molecular genetics. Barnes et al. (1996), for example found that the 12q15-q24.1 region of chromosome may contain a gene(s) controlling asthma and the associated 'high total $\mathrm{IgE}^{\prime}$ trait. However, there is still a little information about the role this gene in the development of asthma. The epidemiological and clinical studies demonstrated a hereditary contribution to the development of COPD such as study showing clustering of COPD in families 
(Tager et al., 1976), increased incidence of COPD or chronic bronchitis in relatives of cases compared to relatives of controls (Madison et al., 1980), and a major gene effect or a genetic component to lung function in families (Astemborski et al., 1985; Rybicki et al., 1990). The genetic basis to COPD has begun to be elucidated and it is likely that several genes will be implicated in the pathogenesis of this disease, including $\alpha 1$-antichemotrypsine, $\alpha 2$-macroglobulin, vitamin D-binding protein and blood group antigens (Sandford et al., 1997).

It is clear that future research of occupationally induced respiratory disorder will largely remain to focus on the contribution of the workplace exposure to the development of chronic respiratory disorders such as chronic non-specific airway diseases (asthma, chronic bronchitis and emphysema), pneumoconiosis and lung cancer, which have a trend to increase in incidence in general population (Weill, 1993). Occupational asthma is the most frequently reported among occupational respiratory diseases (Ross et al., 1995). However, the true prevalence of asthma is difficult to ascertain due to the lack a standard definition and the variations in epidemiologic methodology that have been used (Kavuru and Wiedemann, 1995). Recent data suggest alarming upward trends in the morbidity, mortality, and the cost of illness related to asthma (Weiss et al., 1992). COPD became the fourth leading cause of death of Americans (National Center for Health Statistics, 1991). Data from the National Health Interview Survey (NHIS) of 1991 suggest that chronic bronchitis is the most prevalent cause $(5.05 \%)$ of COPD, followed by emphysema (0.16\%) (Adam and Benson, 1992). Classic tools namely lung function measurements and standardized questionnaire have a significant shortcoming for screening of occupational obstructive lung diseases, as well as chronic non-specific airway disease. As it was demonstrated in this dissertation, that although the forced oscillation technique (FOT) is less sensitive compared to flow volume curve measurements, it is also a useful method for screening of airway obstruction in occupational settings. Since FOT give an additional value in the mechanical characteristic during spontaneous breathing, it should be listed as a supplementary method in the detection of airway obstruction. The finding that blood spontaneous IL-8 production is higher in workers with bronchitic symptoms seems very promising and giving an opportunity in application of molecular epidemiology into future of research in the occupational setting. However, IL-8 is a broad spectrum pro-inflammatory cytokine which is increased in many types of inflammation. Particularly challenging remains the prospect of developing biomarkers both in peripheral blood and in nasal lavage to identify susceptibility to an untoward response and uncover early indicators of the disease process. Another challenge is to detect or to quantify occupational exposure since workers can be exposed to many and complex potential workplace hazards such as chemical and biological agents. 


\section{References}

Adam PF and Benson V (1992) Current estimates from the National Health Interview Survey, 1991. National Center for Health Statistics. Vital Health Stat 10 (184).

Arm JP and Lee TH (1992) The pathobiology of bronchial asthma. Adv Immunol 51:323382 .

Astemborski JA, Beaty $\mathrm{TH}_{s}$ Cohen BH (1985) Variancecomponents analysis of forced expiration in families. Am J Med Genet 21:741-753.

Barnes KC, Neely JD, Duffy DL, Freidhoff LR, Breazeale DR, Schou C, Naidu RP, Levett PN, Renault B, Kucherlapati R, Iozzino S, Ehrlich E, Beaty 'TH, Marsh DG (1996) Linkage of asthma and total serum IgE concentration to markers on chromosome $12 \mathrm{q}$ : evidence from Afro-Caribbean and Caucasian populations. Genomics 37:41-50.

Becklake MR (1989-a) Occupational exposure: Evidence for a causal relationship with chronic obstructiwe pulmonary disease. Am Rev Respir Dis 140:85-91.

Becklake MR (1989-b) Occupational pollution. Chest 196:372-378.

Blaski CA, Watt JL, Quinn TJ, Thorne PS, Schwartz DA (1996) Nasal cellularity, grain dust and airflow obstruction. Chest 109:1086-1092.

Broaddus VC, Hebert CA, Vitangcol RV, Hoeffel JM, Bernstein MS, Boyland AM (1992) Interleukin-8 is a major neutrophilic chemotactic factor in pleural fluid of patients with empyema. Am Rev Respir Dis 146:825-830.

Devlin RB, McDonnell WF, Mann R, Becker S, House DE, Schreinemachers D, Koren HS (1991) Exposure of humans to ambient levels of ozone for $6.6 \mathrm{~h}$ causes cellular and biochemical changes in the lung. Am J Respir Cell Mol Biol 4:72-81.

Donnelly SC, Strieter RM, Kunkel SL, Walz A, Robertson CR, Carter DC, Grant IS, Pollok A], Haslett C (1993) Interleukin-8 and the development of adult respiratory distress syndrome in at risk patient group. Lancet 341:643-647.

Hauser R, Garcia-Closas M, Kelsey KT, Christiani DC (1994) Variability of nasal lavage polymorphonuclear leukocyte counts in unexposed subjects: Its potential utility for epidemiology. Arch Environ Health 49:267-272.

Hessel EM, Van Oosterhout AJM, Van Ark I, Van Esch Betty, Hofman Gerard, Van Loveren

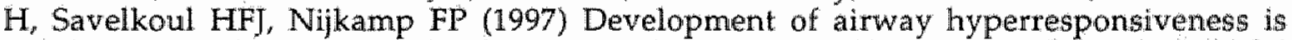
dependent on interferon- $\gamma$ and independent of eosinophil infiltration. Am J Respir Cell Mol Biol 16:325-334.

Hoidal JR (1994): Pathogenesis of chronic bronchitis. Semin Respir Infect 9:8-12.

Kavuru MS and Wiedemann HP (1995) Chapter 9: Asthma. In: George RB, Light RW, Matthay MA, Matthay RA (Eds) Chest medicine, essentials of pulmonary and critical care medicine. Baltimore, Williams \& Wilkins, pp.163-200.

Keating VM, Collins PD, Scott DM, Barnes PJ (1996) Differences in Interleukin-8 and Tumor Necrosis Factor-alpha in induced sputum from patients with chronic obstructive pulmonary disease or asthma. An J Respir Crit Care Med 153:530-534. 
Kou K, Kawano $Y$, Yoshizawa $I_{*}$ Noma $T$ (1994) Analysis and regulation of interferongamma production by peripheral blood lymphocytes from patients with bronchial asthma. Arerugi $43: 482-491$.

Lynch JP, Standiford TJ, Rolfe MW, Kunkel SL, Strieter RM (1992) Neutrophilic alveolitis in idiopathic pulmonary fibrosis. Am Rev respir Dis 145:1433-1439.

Madison $\mathbb{R}$, Zelman $\mathbb{R}$, Mittman $C$ (1980) Inherited risk factors for chronic lung disease. Chest 77 (Suppl. 2):255-257.

Morgan WKC (1986) On dust, disability and death. Am Rev Respir Dis 134:639-641.

Mosmann TR and Coffman RL (1989) $\mathrm{Th}_{1}$ and $\mathrm{Th}_{2}$ cells: different patterns of lymphokine secretion lead to different functional properties. Annu Rev Immunol 7:145-173.

National Center for Health Statistics (1991) Advance report of final mortality statistics. Monthly Vital Statistics Report 42 (Suppl.):1993.

Neild JE, Twort CHC, Chinn S, McCormack S, Jones TD, Burney PGJ, Cameron IR (1989) The repeatability and validity of respiratory resistance measured by the forced oscillation technique. Respir Med 83:111-118.

Noah TL, Henderson FW, Henry MM, Peden DB, Devlin DB (1995-a) Nasal lavage cytokines in normal, allergic, and asthmatic school-age children. Am J Resp Crit care Med 152:1290-1296.

Noah TL, Henderson FW, Wortman IA, Devlin RB, Handy J, Koren HS, Becker S (1995-b) Nasal cytokine production in viral acute upper respiratory infection of childhood. I Infect Dis 171:584-592.

Persson CGA, Svensson C, Greiff L, Anderson M, Wollmer P, Alkner U, Erjevalt I (1992) The use of the nose to study inflammatory response of the respiratory tract Thorax 47: 9931000.

Richman-Eisenstat JB, Jorens PG, Hebert CA, Ueki I, Nadel JA (1993) Interleukin-8: an important chemotrattant in sputum of patients with chronic inflammatory airway diseases. Am J Physiol 246:413-418.

Rise GC. Ahlstedt S, Larsson S, Enader I Jones I, Larsson P, Andersson B (1995) Bronchial inflammation in chronic bronchitis assessed by measurement of cell products in bronchial lavage fluid. Thorax 50:360-365.

Robinson DS, Hamid Q, Ying S, Tsicopoulos A, Barkans J, Bentley AM, Corrigan C, Durham SR Kay AB (1992) Predominant $T_{2}$-like bronchoalveolar $\mathbb{I}$-lymphocytes population in atopic asthma. N Engl J Med 326:298-304.

Ross DJ Sallie BA, MCDonald JC (1995) SWORD '94: surveillance of work-related and occupational respiratory disease in the UK. Occup Med 45:175-178.

Rybicki BA, Beatry TH, Cohen BH (1990) Major genetic mechanism in pulmonary function. J Clin Epidemiol 43:667-675.

Sandford AJ, Weir TD, Pare PD (1997) Genetic risk factors for chronic obstructive pulmonary disease. Eur Respir ] 10:1380-1391. 
Stanescu DC, Fesler R, Variter C, Fans A, Brasseur L (1975) A modified measurement of respiratory resistance by forced oscillation during normal breathing. I Appl Physiol 39:305311.

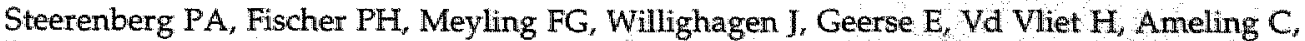
Boink ABTJ, Dormans J, Van Bree L, Loveren HV (1996) Nasal lavage as a tool for health effect of photochemical air pollution. Hum Exp Toxicol 15:111-119.

Tager IB, Rosner B, Tishler PV, Speizer FE, Kass EH (1976) Household aggregation of pulmonary function and chronic bronchitis. Am Rev Respir Dis 114:485-492.

Vercelli D (1995) Immunoglobulin E regulation in human, 1989-1994. Allergy 50:5-8.

Walker C, Bauer W, Braun RK, Menz G, Braun P, Schwartz F, Hansel TT, Villiger B (1994) Activated $T$-cells and cytokines in bronchoalveolar lavages from patients with various lung diseases associated with eosinophilia. Am J Respir Crit Care Med 150:1038-1048.

Weil H (1993) Future of research into occupational lung disease. Br I Ind Med 50:481-483.

Weiss $\mathbb{K B}$, Gergen PJ, Hodgson TA (1992) An economic evaluation of asthma is the United States. N Engl J Med 326:862-866.

Wouters EFM (1990) Total respiratory impedance measurement by forced oscillations: a non-invasive method to assess bronchial response in occupational medicine. Exp Lung Res $16: 25-40$. 


\section{Chapter 8}

\section{SUMMARY}

This dissertation reviews the role of occupational exposure in the nature of chronic non-specific airway diseases (CNSAD), possible immuno-pathologic mechanism involved, currently applied methods, and the possibility of biomarkers as an alternative for the detection of these diseases. CNSAD consist of three separate diseases, namely asthma, chronic bronchitis and emphysema. Diffuse airway obstruction is considered as the common pathophysiological characteristic. The growth of knowledge about the disease leads to refinements in and standardization of study design and methods of analysis. Occupational exposures are important in the disease induction, because the timing, intensity and duration of exposure are often known more accuretely compared to nonoccupational exposure. However, individual genetic susceptibility and characteristics such as cigarette smoking have been identified as important risk factors. The dimention of lung diseases in The Netherlands is indicated by a number of prevalence studies showing that $10-20 \%$ of adult men and $5-10 \%$ of adult women have CNSAD requiring medication (Jorna, thesis, 1994). The presented data show the need for a proper appreciation and quantification of occupational causes. This is underscored by indication that a proportion of occupational lung diseases remains unrecognized, because they are rarely as specific as they used to be, no longer take epidemic proportion and arise in more susceptible individuals. On the other hand, the incidence of these diseases are increased in the general population.

Classic tools such as flow volume curves and standardized questionnaires on respiratory symptoms have serious shortcomings for early detection of CNSAD and discerning susceptible individuals. Health prevention of adverse airway effects from occupational exposure can be done through occupational risk analysis and preventing the workers from workplace exposure. It may be very challenging and often very difficult, because many agents appear in an diverse range of materials and processes. Recently, molecular epidemiology has been developed to illuminate disease mechanisms. Detection of immunological and pathophysiological changes really offers an alternative opportunity to prevent adverse airway effects from occupational exposure.

The general aim of this dissertation was to evaluate a multifunctional approach to detect CNSAD with special interest in occupational asthma and chronic bronchitis. Assessment of inflammatory markers both in blood and NAL fluid was done intensively in order to use inflammatory markers as an alternative or a complementary tool to detect those diseases in occupational setting.

Classic tools namely lung function (impedance and flow volume) measurements and standardized questionnaires have repeatedly been approached in 136 chemical workers from 7 different production processes during a 5 year follow-up study. It is described in Chapter 2. The outcome of of impedance measurements and flow vollume curves was compared, and the relationship between lung function decline and specific production process and 
smoking was analysed. The prevalence of airway obstruction ( $\mathbb{F E V}_{1}<80 \%$ predicted) at both time-points was about $5 \%$ but did not necessarily include the same subjects. The average decline in $\mathrm{FEV}_{1}$ over five years was $200 \mathrm{~mL}$ (predicted decline: $160 \mathrm{~mL}$ ). Most impedance parameters correlated to flow volume parameters in both years. However, a rapid 5-year decline of FEV $(>330 \mathrm{~mL})$ was only accompanied by a significant decrease in the reactance at $8 \mathrm{~Hz}(\times 8)$ and an increase in the resonance frequency $\left(f_{0}\right)$. Interestingly, decline in $F E V_{1}$ was significantly dependent on age, years of employment, pack-years, $F E V_{1}$, and all impedance parameters at a start in $1990\left(\mathrm{r}^{2}=0.13, \mathrm{p}=0.01\right)$. Similarly, the increase in $f_{0}$ was significantly dependent on age, years of employment, pack-years, $f_{0}$, $\mathrm{FEV}_{1}, \mathrm{FVC}_{,}$PEF and MMEF at a start $\left(\mathrm{r}^{2}=0.32, \mathrm{p}<0.01\right)$. Rapid decliners in $\mathrm{FEV}_{1}$ were relatively more present in acids (Relative risk $(R R)=2.14$ ), maintenance workers ( $R R=2.1)$ and bulk/transport $(R R=1.78)$, but none of these ratios' was significant. Lung function, however, was significantly lower in the bulk/transport workers $(n=14)$ compared to the rest, based both on flow volume $\left(\mathrm{FVC}, \mathrm{FEV}_{1}\right)$ and impedance $\left(\mathrm{X} 8, \mathrm{f}_{0}\right)$ measurements. Smoking had a significant effect on most flow volume parameters but only for frequency dependence among the impedance outcomes. It is concluded that alterations in impedance parameters do reflect changes in flow volume curves induced by age, smoking and occupational exposure. Therefore, these data are a valuable extension to current cross-sectional data.

In Chapter 3, several peripheral blood cytokines which are related to occupational asthma (serum IL-4, IL-5, and IFN- $\gamma$ ) and chronic bronchitis (proinflammatory cytokines; whole blood IL-8 and TNF- $\alpha$ ) were assessed in 106 chemical workers during a routine yearly medical examination in 1995 . Those markers were also related to occupational exposure that might be useful for early detection of (pre) occupational respiratory diseases such as occupational asthma and chronic bronchitis or occupational exposures in practical use. Whole blood spontaneous IL-8 release was significantly higher in workers with bronchitis $(p<0.05)$ or chronic bronchitis $(p<0.01)$ compared to workers without those respiratory symptoms, also after correction for age, pack-years, and blood lymphocyte numbers. A secondary analysis with a matched group verified these specific effects in this group. No correlation was present between specific cytokines and asthmatic symptoms, lung function, or chronic airway obstruction; serum IL-5 was significantly correlated $(p<0.05)$ to age and pack-years, and blood TNF- $\alpha$ release was significantly higher $(p<0.05)$ in non-smokers compared to (past and current) smokers. Moreover, lung function was significantly lower $(p<0.01)$ and serum IL -4 was significantly increased $(p<0.05)$ in workers exposed to fertilizer dust. These data suggest that blood IL-8 may be considered as a useful marker for bronchitis. With increasing age and cigarette smoking, the ability and capacity to produce certain cytokines tends to decrease. Apart from IL-8 and IL-4 that were associated to bronchitis and airway obstruction related to high-dust exposure, the data do not support the widespread use of blood cytokines as a tool for screening in occupational practice.

The prevalence of pneumoconiosis, airway obstruction and respiratory symptoms in retired coal workers is described in Chapter 4 . The relation between blood cytokines and respiratory impairment was investigated in coal workers. A 
number of other cytokines known to be involved in coal dust induced responses, were studied in serum and monocyte supernatants of 104 retired coal workers. Short-lived cytokines TGF- $\beta$ and IL-6 were measured in monocyte incubations, whereas IL-8, soluble TNF-R55 and -R75 were determined in serum. Spontaneous IL-6 release from monocytes was significantly lower in coal workers with bronchitis and those with airway obstruction. Higher serum IL-8 levels were associated with better lung function (flow volume and impedance). Inverse correlation between impedance values and soluble TNF-R55 were observed, although medication was found to be a confounder. The data suggest that TNF- $\alpha$ and $\pi-8$ are related to respiratory impairment in workers exposed to coal dust. These finding further support the role of these cytokines in the pathogenesis of respiratory impairment such as chronic bronchitis and airway obstruction.

In Chapter 5, nasal lavage (NAL) was used as a method to study mechanism in endotoxin induced upper and lower respiratory diseases in a short-term longitudinal study design. NAL, lung function and exposure measurement have been conducted in a small group of cotton workers in a textile factory. Proinflammatory cytokine release (IL-6 and IL-8), several attenuating factors (sTNF-R75, sICAM-1), and markers of cell response (uric acid, albumine) were masured in NAL and correlated to cotton dust and endotoxin exposure, as well as to short-term changes in lung function. At the exposure levels of cotton dust $1.10 \mathrm{mg} / \mathrm{m}^{3}$ or endotoxin $2,869 \mathrm{EU} / \mathrm{m}^{3}$ several inflammatory markers in NAL such as IL-8, sTNF-R75, and albumin tended to increase through the measurement period with increasing airborne endotoxin concentration (in 6 workers who had a paired measurements in week 1 and 6). Although no statistical significance was reached, airborne endotoxin exposure and all inflammatory markers in NAL were relatively higher in cotton workers with lung function response. The data suggest that inflammatory markers in NAL are associated to repeated airborne endotoxin exposure.

In order to investigate the relationship between inflammatory markers in serum and NAL and interrelationship among those inflammatory markers in NAL, other inflammatory markers such as interleukins (IL-4, IL-5), interferon- $\gamma$ (IFN- $\gamma$ ), markers of venule exudation (albumin, uric acid), and response to endotoxin exposure : lipopolysaccaride (LPS) binding protein (LBP) and bactericidal/permeability-increasing protein (BPI) were measured both in cotton workers and controls. It is described in Chapter 6. Most inflammatory markers both in controls and cotton workers were readily detectable in serum, but not in NAL, except for the proinflammatory IL-8. IL-8 was detectable in nearly all NAL samples, while IL-6 was only detectable in a fraction (3/28), and IL-4, IL-5 and IFN- $\gamma$ in one case. Endotoxin binding proteins (LBP and BPI) were readily detectable in both serum and NAL. Interestingly, LBP in NAL was negatively correlated to serum levels $(r=-0.88)$ in controls. BPI was correlated to IL-8 in NAL as the major chemoattractant for PMN. The strongest relation between serum and NAL was observed for STNF-R75. The data suggest that only markers predominantly present in serum showed a significant correlation with $\mathbb{N A L}$ levels, confirming plasma exudation as its main source. On the other hand, markers with predominant epithelial (IL-8) or granulotype (BPI) origin were also related to LBP and STNF-R75, thereby impeding a clear-cut interpretation as nasal 
biomarker. Experimental and clinical studies are needed to further understand the major sources and significance of inflammatory markers in the upper airways.

These studies concluded that there are three important things. Firstly, although the forced oscillation technique (FOT) is less sensitive compared to forced expiratory flow volume measurements, it is a useful method to screen airway obstruction in workers exposed to chemicals. Changes in impedance parameters and effects of smoking and occupational exposure reflect or parallel changes in spirometric indices. Secondly, whole blood spontaneous IL-8 production may be considered as a useful marker for bronchitis, but can not rule out the involvement of other cytokines. Unfortunately, no data support the widespread use of blood cytokines as a tool for screening in occupational practice. Thirdly, biomarkers predominantly present in serum showed a significant correlation with those in NAL, confirming plasma exudation as its main source. On the other hand, markers with predominant epithelial (IL-8) or granulotype (BPI) origin were also related to LBP and sTNF-R75, thereby impeding a clear-cut interpretation as nasal biomarker. Experimental and clinical studies are needed to further understand the major sources and significance of inflammatory markers in the upper airways.

Since FOT parameters do reflect changes in flow volume curves and give an additional value in the mechanical characteristic during spontaneous breathing, it should be listed as a supplementary method in the detection of airway obstruction. The finding that whole blood spontaneous IL-8 production is increased in workers with bronchitic symptoms seems very promising and giving an opportunity in application of molecular epidemiology into future of researches in the occupational setting. Particularly challenge remains in the prospect of developing biomarkers both in peripheral blood and in NAL to identify susceptibility to an untoward response and uncover early indicators of the disease process. Another challenge is to detect or quantify occupational exposure since workers can be exposed to many and complex potential workplace hazards such as chemical and biological agents. 


\section{ACKNOWLEDGEMENTS}

First of all, I want to thank my mother Soenarsih as well as my wife Yetty and my sons Andi and Anton for invaluable support and stimulating from Indonesia during studying to pursue a Ph.D. degree at Maastricht University, The Netherlands.

I am seriously indebted to Professor Jos C.S. Kleinjans, Ph.D. and Paul J.A. Borm, Ph.D., who offered me an opportunity to do some researches at Department of Health Risk Analysis and Toxicology, Maastricht University, on cytokines as biomarkers for respiratory impairments in workers exposed to coal dust, chemicals, and cotton dust with guideline in occupational health. This has been of major importance for the final result.

The chemical, coal and cotton workers are gratefully acknowledged. Without their participation, this study would never have been possible. I always remember Eduard Kusters, MD., Mr. G. Sambaer, Conny Becker, MD., and Mr. Han van der Leeuw for their assistance and hospitality during field study in the factories in Antwerpen, Belgium and Sittard, The Netherlands. I thank to people who have contributed to these studies. I could always depend on Drs. Brigitte Willemse and Drs. Manon Jetten for serological measurement for cytokines, and Roel P.F. Schins, Ph.D. the toedeledoki supervisor for laboratory works gave me innovations during writing papers. Roel, please just keep behaving in the same way you do. They are co-authors in several papers presented here. The last Drs. Ivo Zwingmann was honest and helpful, always gave me some information on football match. Rob Stierum Ph.D., Drs. Roger Godschalk, Drs. Harma Albering and Drs. Ingrid Vermeer always take care on software which I work on the computer. Drs. Irene Welle assisted and explained to me patiently how to measure cytokines with ELISA technique. Mr. Harold Smeets from Department of Pulmonology, Maastricht Academic Hospital, taught me measuring impedance of the respiratory system using the forced oscillation technique. Ms. Mary Claire van den Voort, Ms. Anke Weynen, and Ms. Caroline Steeghs have provided me some office stationeries that I needed during writing papers and preparing this book. Ms. Els Rhijnburger always puts the Nuffic newsletters on may mailbox and Mr. Edwin Moonen lent me a bicycle for 3 days during vakgroep-uitstapje in 1996. Mr. Ben van Agen, Mr Lou Maas, Mr. Maxeli van Herwijnen always addressed me alles goed met jou?, and the new comer, Drs. Ad Knaapen, is also friendly and addresses me hallo..maestro 1. Other colleagues at Department of Health Risk analysis and Toxicology, Maastricht University that I cannot mention all of them in such a limited space. They really impressed me with good human relations, and without a doubt, left indelible imprints in my memory. Some people of Indonesian community in the Netherlands that I cannot mention all of them, and also my last year roommates Zhai Rihong MD. and Ahmad Besarati Nia MPH, contributed significantly to my social life. Thank you very much.

Finally, I thank Indonesian Six Universities Development and Rehabilitation (SUDR) program that have provided a fellowship and The Netherlands Universities Foundation for International Cooperation (NUFFIC) which has administered my study in The Netherlands. 


\section{CURRICULUM VITAE}

Soedjajadi Keman was born on March $15^{\text {th }} 1952$ in Surabaya, Indonesia. He was graduated from State Senior High School 2 Surabaya in 1971, and went to Faculty of Medicine, University of Airlangga, Surabaya, Indonesia, where he was graduated as a Medical Doctor (MD) in 1978. He became a lecturer's assistant at Department of Public Health, Faculty of Medicine, University of Airlangga, Surabaya, and worked as a leader of 3 rural health centers (Puskesmas) at districts of Puspo, Tosari, and Pasrepan, County of Pasuruan, East Java, for two years. In 1981 he went to Post Graduate School of University of Airlangga and was graduated as a Master of Science in Public Health (MSPH) in 1983. After working as a lecturer at the same department for 11 years, in 1994 he went to far away for working as a fellow's researcher at Department of Health Risk Analysis and Toxicology, Maastricht University, The Netherlands to pursue a Ph.D. degree on a grant by The Indonesian Six Universities Development and Rehabilitation (SUDR) program. After promotion, he will continue working for Faculty of Public Health, University of Airlangga, Surabaya, Indonesia. 


\section{LIST OF PUBLICATIONS AND ABSTRACTS}

\section{Publications}

1. Keman S, Willemse B, Wesseling GJ, Kusters E, Borm PJA (1996) A five year followup of lung function among chemical workers using flow volume and impedance measurements. Eur Respir J 9:2109-2115.

2. Schins RPF, Keman S, Borm PJA (1997) Blood antioxidant status in coal miner induced respiratory disorders: a longitudinal evaluation of multiple biomarkers. Biomathers 2:45-50.

3. Keman S, Willemse B, Tollerud DJ, Guevarra L, Schins RPF, Borm PJA (1997) Blood interleukin-8 production is increased in chemical workers with respiratory symptoms. Am J Ind Med, In press.

4. Keman S, Jetten M, Douwes J, Borm PJA (1997) Inflammatory markers in nasal lavage of cotton workers. Relation to endotoxin exposure and lung function changes. Int Arch Occup Environ Health, In press.

5. Keman S, Jetten M, Schins RPF, Borm PJA (1997) Relation between inflammatory markers in serum and nasal lavage. Exp Toxicol Pathol, In press.

6. Borm PJA, Keman S, Jetten M, Kant IJ, Manni JJ, Hidayat S, Soeprapto H (1997) Nasal inflammation as a mediator of wood dust induced effects in upper and lower respiratory tract. Exp Toxicol Pathol, In press.

7. Borm PJA, Keman S, Jetten M, Schins RPF (1997) Endotoxin-binding proteins in nasal lavage and plasma of cotton workers. J Allergy Clin Immunol. Submitted.

\section{Abstracts}

1. Keman S, Schins RPF, Lenaerts L, Borm PJA (1995) 10 year longitudinal changes in FEV 1 of coal miners are related to later progression of CWP and TNF- $\alpha$ production by blood monocytes. Am J Res Crit Care Med 151:A710.

2. Keman S, Willemse B, Wesseling GJ, Borm PJA (1996) A longitudinal study comparing flow volume curves and impedance measurements. Am I Res Crit Care Med 153:A98.

3. Schins RPF, Keman S, Borm PJA (1996) Blood antioxidants and coal dust induced respiratory disorders. A Multi-markers approach. Am J Res Crit Care Med 153:A473.

4. Keman S, Willemse B, Schins RPF, Guevarra L, Tollerud DJ, Borm PJA (1996) Blood cytokines as markers of respiratory impairment in chemical workers. Am J Res Crit Care Med 153:A794.

5. Jetten M, Douwes J, Keman S, Schins RPF, Borm PJA (1997) Nasal inflammatory responses in workers exposed to cotton dust/endotoxin. 6th International Inhalation Symposium: on Relationship between Respiratory Disease and Exposure to Air Pollution. Hannover, Germany, 24-28 February 1997.

6. Schins RPF, Keman S, Jetten M, Douwes J, Borm PJA (1997) Nasal inflammatory responses in workers exposed to cotton dust. Am I Res Crit Care Med 155:A961.

7. Borm PJA, Jetten M, Keman S, Douwes J, Schins RPF (1997) BPI and LPS binding protein in nasal lavage of workers exposed to cotton dust/endotoxin. Am J Res Crit Care Med 155:A900. 